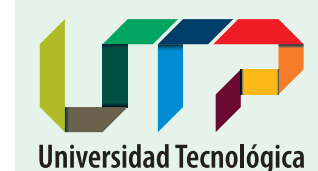

Universidad Tecnológica de Pereira

Facultad

Ciencias de la Educación

\title{
EL DIÁLOGO NOS FORJA Infancia y Ciudadanía
}
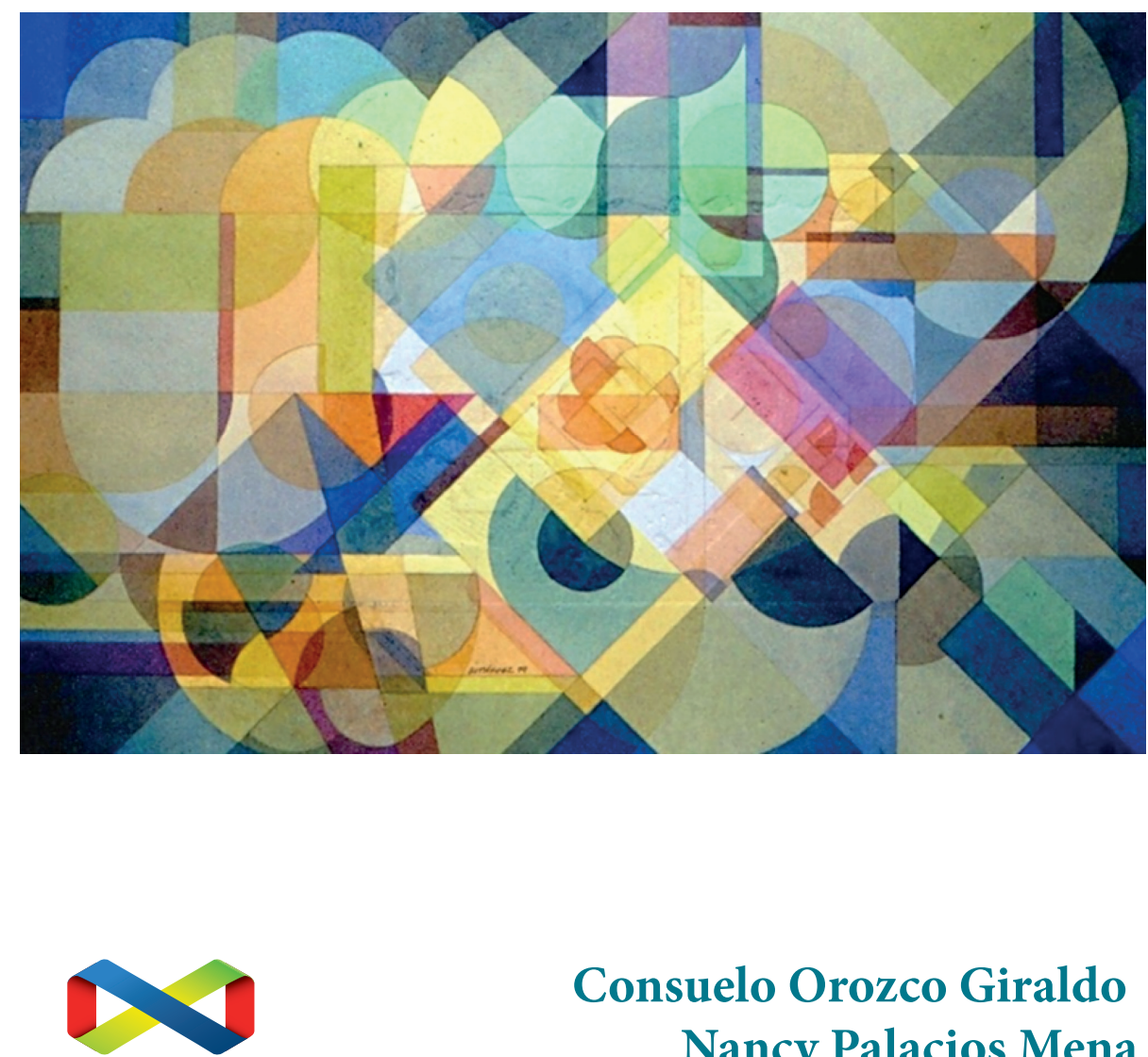

Consuelo Orozco Giraldo
Nancy Palacios Mena

Editorial UTP 
Consuelo Orozco Giraldo, (Santa Rosa de Cabal, Risaralda, Colombia, 1978). Doctora en Ciencias de la educación, Universidad Tecnológica de Pereira; Magíster en Comunicación Educativa por la misma Universidad. Licenciada en Pedagogía Infantil, Universidad del Tolima. Profesora asistente de la facultad de educación y directora del Doctorado en Ciencias de la Educación de la Universidad Tecnológica de Pereira.

Autora de los libros: De la educación a la lengua. Los fines y los medios (2014); Conexión emoción-razón. En busca de la unidad perdida en el plano educativo (2015); Sociología del desarrollo (2016).

Ha recibido los reconocimientos: a la labor como docente catedrática de la modalidad de educación a distancia de la Universidad del Tolima, 2013. Tesis de doctorado laureada, Universidad Tecnológica de Pereira, 2015. Graduado destacado, categoría Academia Investigación, Universidad del Tolima, 2015. Pertenece al grupo de investigación Filosofía posmetafísica.

consuelorozco@utp.edu.co

Nancy Palacios Mena, (Quibdó, Chocó, Colombia, 1978). Doctora en ciencias sociales niñez y juventud convenio de la Fundación Centro Internacional de Educación para el Desarrollo Humano CINDE y la Universidad de Manizales. Licenciada en ciencias sociales y magister en sociología en la universidad del Valle. Profesora de la Universidad del Tolima. Profesora asistente de la Facultad de Educación de la Universidad de los Andes. Bogotá.

Ganadora del PREMIO COMPARTIR AL MAESTRO, 2015. Tesis de doctorado Magna cum laude, 2015.

$\mathrm{Ha}$ publicado artículos en revistas especializadas nacionales e internacionales y capítulos de libros.

n.palaciosm@uniandes.edu.co 


\section{El diálogo nos forja Infancia y ciudadanía}

Consuelo Orozco Giraldo

Nancy Palacios Mena

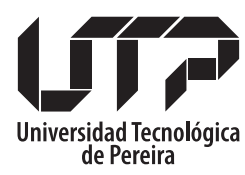

Colección Trabajos de Investigación

Facultad de Ciencias de la Educación 2017 
Orozco Giraldo, Consuelo

El diálogo nos forja : infancia y ciudadanía / Consuelo Orozco

Giraldo y Nancy Palacios Mena. - Pereira : Editorial Universidad

Tecnológica de Pereira, 2017.

125 páginas. -- (Colección Trabajos de Investigación).

ISBN: 978-958-722-281-4

1. Comprensión lingüística 2. Pragmática lingüística 3. Aprendizaje significativo 4. Escritura - Enseñanza 5. Lectura - Enseñanza 6. Mé-

todos de enseñanza - Aprendizaje 7. Sociología de la educación.

CDD. 372.47

(C) Consuelo Orozco Giraldo, Nancy Palacios Mena, 2017

(c) Universidad Tecnológica de Pereira

Primera edición

Universidad Tecnológica de Pereira

Vicerrectoría de Investigaciones, Innovación y Extensión

Editorial Universidad Tecnológica de Pereira

Trabajo de Investigación:

Proyecto Didáctica de la provocación bajo el signo de una antropología paradójica inscrito con el código 1-15-2

Coordinador editorial:

Luis Miguel Vargas Valencia

luismvargas@utp.edu.co

Teléfono 3137381

Edificio 9, Biblioteca Central "Jorge Roa Martínez"

Cra. 27 No. 10-02 Los Álamos,

Pereira, Colombia

www.utp.edu.co

\section{Montaje y producción}

Centro de Recursos informáticos y Educativos CRIE

Universidad Tecnológica de Pereira

Ilustración Cubierta:

Rubén Darío Gutiérrez

Reservados todos los derechos 


\section{CONTENIDO}

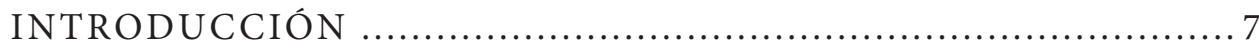

A Manera de Proceso Metodológico …................................................................................................... 11

CAPÍTULO I: DESAPRENDER. NO ENSEÑAR

COMO APRENDIMOS (Consuelo Orozco Giraldo) ................. 17

\section{TENDENCIAS Y COMPRENSIONES LINGÜÍSTICAS: VIGENCIA}

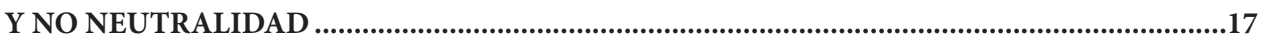

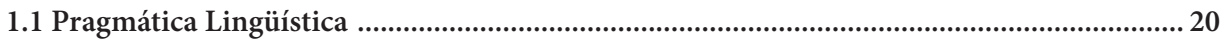

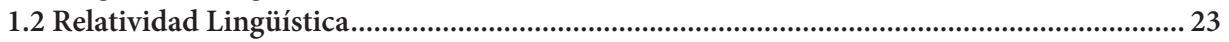

II. DESFRAGMENTACIÓN EN LA PRIMERA INFANCIA, TAREA DE TODOS. .......................26

2.1 Lenguaje, lectura y escritura en la primera infancia ..................................................................26

2.2 Pasado-presente y presente-futuro de la educación infantil ...................................................... 27

2.3 Paradigma Conductista: el aprendizaje como cambio de conducta. .......................................29

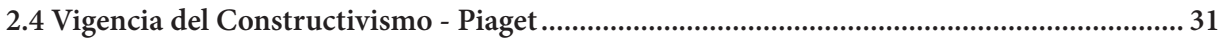

2.5 Vigencia del Socioconstructivismo - Vygotsky ............................................................................... 34

2.6 Pedagogía y educación integral. Una obligación, un derecho en la primera infancia. ......... 39

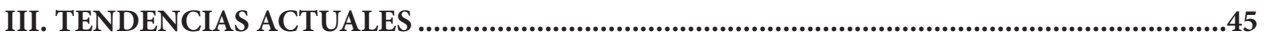

3.1 Experiencia investigativa. Cambios de paradigmas lingüísticos .............................................. 48

3.2 Habilidades comunicativas. Virus y bacterias necesarias en la primera infancia....................49

3.3 Niveles de desarrollo del sistema de escritura en el niño .......................................................... 52

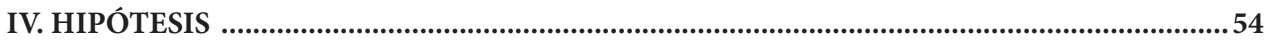

4.1 A manera de hipótesis generales...............................................................................................54

4.2 A manera de hipótesis específicas................................................................................................55

CAPÍTULO II: EDUCACIÓN PARA LA CIUDADANÍA.

CONTEXTO SOCIO HISTÓRICO (Nancy Palacios Mena) ........61

\section{LA EDUCACION PARA LA CIUDADANÍA Y LA DEMOCRATIZACION}

DE LA ESCUELA EN COLOMBIA CONTEXTO SOCIOHISTÓRICO.......................................61

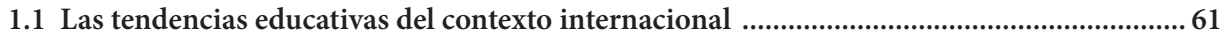

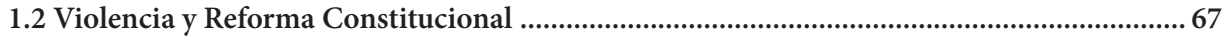

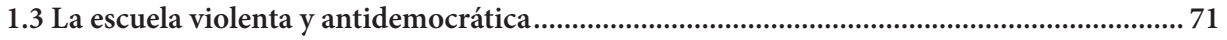

1.4 La democratización de la vida escolar en Colombia ................................................................... 77 
1.4.1 La educación cívica: antecedente de la educación para la democracia|......................... 77

1.4.2 Los objetivos y las metas de la democratización de la escuela ....................................... 79

1.4.3 Ejes del proyecto de democratización de la escuela colombiana ................................... 84

1.5 Reformas en el currículo y en la organización social de la escuela............................................ 91

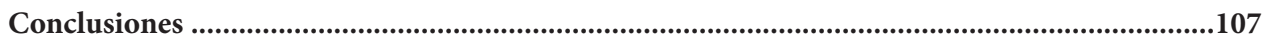




\section{GRÁFICAS}

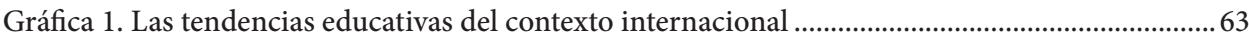

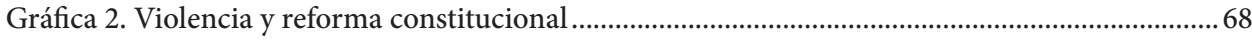

Gráfica 3. La escuela violenta y antidemocrática .................................................................................. 71

Gráfica 4. Democratización de la vida escolar .................................................................................. 78

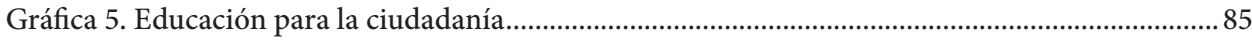

Gráfica 6. Perspectivas teóricas y propuestas pedagógicas para el desarrollo del juicio moral.

Fuente. Cortés (2012), Citando a Yánez y Fonseca (2003), y a Mesa (2004)........................................90

Gráfica 7. Reformas en el currículo y en la organización social de la escuela ......................................92 


\section{CUADROS}

Cuadro 1. Estándares básicos de competencia de competencias ciudadanas......................................96

Cuadro 2. Fragmento de la presentación de los lineamientos

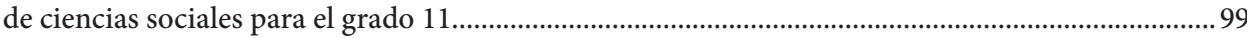

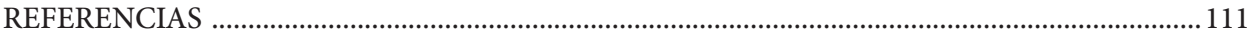




\section{INTRODUCCIÓN}

En los últimos 30 años en todo el contexto latinoamericano la escuela ha vivido un estado de permanente renovación y reforma. Estos cambios obedecen a un interés por cumplir con compromisos internacionales como son las metas de consolidación de la democracia, la reducción de la pobreza y la desigualdad, dichas metas se han traducido en la ejecución de actividades concretas como la ampliación de la cobertura escolar y la búsqueda de la eliminación del analfabetismo.

A nivel nacional, los objetivos de renovación de los diferentes países han estado orientados a transformar las relaciones entre los actores escolares, la renovación de los currículos y las innovaciones de las estrategias pedagógicas. En lo concerniente a las relaciones entre los actores escolares, las reformas han estado enfocadas principalmente a cambiar la verticalidad en el trato entre docentes y directivos docentes, se ha pretendido garantizar que la escuela sea un espacio de relaciones más horizontales donde cada uno de sus actores se constituyan en sujetos de derechos, con un rol activo en todas las decisiones de la vida escolar.

En lo concerniente a los currículos y las estrategias pedagógicas las reformas han estado enfocadas en dos frentes, la creación de sistemas escolares más pertinentes y en función de las necesidades, las problemáticas y las características de cada país y la obtención de mejoras sustanciales en los resultados académicos, algunos países han centrado este último objetivo en la mejoría de sus resultados en las evaluaciones internacionales, principalmente de la prueba PISA. 
Las respuestas de las instituciones educativas a los cambios no han sido del todo bien recibidas, entre otras cosas, porque que las reformas además de inconsultas, son formuladas por personas que no conocen el interior de la escuela, sus necesidades y expectativas. Otro aspecto que se crítica de las reformas planteadas por los Ministerios de Educación desde el interior de la escuela, es que no siempre hay un tiempo prudencial entre una reforma y otra, la crítica en este sentido ha sido básicamente, que apenas se está comprendiendo los objetivos y los principios para la ejecución de una reforma cuando ya llega otra, sin tener el tiempo suficiente para asimilarla, y evaluarla.

El libro es una reflexión desde dos frentes: el pedagógico en el primer apartado y el social en el segundo, ambos capítulos ponen en evidencia necesidad de repensar la educación ciudadana desde la primera infancia. La poca aceptación que han tenido las reformas en el contexto escolar, y que muchas de ellas no hayan tenido el éxito esperado, no niega en ningún caso el impacto que ha tenido el espíritu reformador en la cotidianidad de los establecimientos educativos. En este libro nos ocuparemos del análisis de dos de estas reformas en el caso colombiano: el debate sobre las prácticas actuales y la reflexión y formulación de nuevas estrategias pedagógicas para la enseñanza de la lectura y la escritura en los primeros niveles de enseñanza y la política gubernamental de democratización de la escuela colombiana y, en función a lo anterior hemos dividido el libro en dos partes.

En la primera parte titulada Desaprender. No enseñar como aprendimos, pretendemos brindar elementos históricos y teóricos que permita a los maestros ser menos ingenuos frente al lenguaje, a la herencia académica y teórica y reflexionar sobre la vigencia de sus prácticas y discursos pedagógicos en general y en la primera infancia en particular. En concordancia con los avances científicos que evidencian el poder del lenguaje, éste primer capítulo brinda protagonismo al lenguaje en general y en la primera infancia en particular. Si el desarrollo del lenguaje está fuertemente ligado al desarrollo cognitivo, si las herramientas lingüísticas limitadas pueden restringir el desarrollo de áreas del pensamiento que requieran mayor complejidad y abstracción, resulta menester adelantar reflexiones como ésta que invitan a comprender posturas o enfoques teóricos clásicos y contemporáneos obligados para quienes se ocupan de la educación en la primera infancia: entre otros, Piaget, Vygotsky y Ferreiro. Este capítulo, finaliza con una tendencia específica que lejos de ser una propuesta didáctica, se propone fomentar la reflexión sobre las prácticas pedagógicas de quienes acompañan los procesos de lectura y escritura en la primera infancia. En la segunda parte, titulada: Educación para la ciudadanía. Contexto socio histórico, 
se analiza la génesis y la dinámica evolutiva del proceso de democratización de la escuela en Colombia, en un primer momento se presentan las tendencias educativas nacionales e internacionales que propiciaron el proyecto democratizador, posteriormente se plantea cómo el clima de reforma constitucional y de violencia que se vivía en el país y en la escuela evidenciaron la necesidad de hacer de los establecimientos educativos, espacios democráticos, finalmente, se reflexiona sobre los ejes alrededor de los cuales giro la propuesta de democratización y se analizan las reformar curriculares que se llevaron a cabo en el marco de dicho proyecto. 



\section{A MANERA DE PROCESO METODOLÓGICO}

Con la claridad que en las humanidades a diferencia de las ciencias duras o exactas no hay un proceso metodológico único que pueda llamarse "real", nos disponemos a continuación a mencionar la forma real como surgió este libro.

$\mathrm{Al}$ estar finalizando la formación doctoral en dos doctorados de diferente áreas de investigación (Consuelo Orozco, doctora en ciencias de la educación; Nancy Palacios doctora en ciencias sociales niñez y juventud) coincidimos no solo el ser docentes de investigación de la licenciatura en pedagogía infantil de la universidad del Tolima con sede en Pereira, sino, además, en tener la pasión por la educación en la primera infancia y la necesidad de aportar al mejoramiento de la calidad educativa en general. Es así como en una de las innumerables conversaciones en el grupo de estudio que conformamos develamos que la formación de los niños no solo podría rastrearse en los discursos y prácticas pedagógicas de docentes y en general de los actores educativos, sino, además, desde la mirada y vivencia de los pequeños como sujetos políticos. Esta era la oportunidad para producir otras formas de orientar procesos ciudadanos y pedagógicos que llegarían a los pequeños a través de los estudiantes de la licenciatura a quienes, como ya se había mencionado, orientábamos la asignatura de investigación y práctica pedagógica. De esta forma, decidimos que de acuerdo a nuestra formación académica en general, y doctoral en particular, iniciaríamos un proceso de investigación riguroso que aportara datos a la comprensión de las tendencias académicas y sociales que estaban construyendo y reconstruyendo la 
formación en general, y en la primera infancia, en particular. En consecuencia, la diferencia en nuestra formación doctoral, lejos de ser una limitación la asumimos como fortaleza que ampliaba nuestra capacidad de comprender el fenómeno educativo. Cada una de las autoras planteo su propia pregunta de investigación, aprovechó su lugar de trabajo y recolectó su información en diferentes contextos y fuentes (conversaciones, diarios de campo, videos, experiencias, interacción con los pequeños, interacción con los estudiantes de la licenciatura, docentes y administrativos), pero existían encuentros en los que se cruzaba información y se formulaban hipótesis conjuntas y se avanzaba en la escritura del presente libro.

La metodología fue de corte cualitativo y documental y abordada desde una pregunta de investigación general y dos preguntas de investigación particulares: la general abarca las dos perspectivas: ¿cuáles son los discursos que circulan sobre democracia y calidad educativa? La pregunta de investigación que impulsó el primer apartado está relacionada con postulados y prácticas pedagógicas que lejos de dar rienda suelta a las competencias de los pequeños parecen centrarse en "evitar pensar": ¿Cuáles son los discursos y prácticas pedagógicas que circulan en la educación infantil? La pregunta de investigación del segundo apartado es ¿Cómo y en qué momento emerge la necesidad de democratizar la escuela colombiana?

La información que dio lugar a la primera parte del libro, fue recolectada de textos e investigaciones actuales, de la reflexión sobre los mismos y de la interacción con estudiantes de la Universidad el Tolima de licenciatura en pedagogía infantil durante la asignatura de investigación y práctica pedagógica. Mientras transcurrían las asesorías investigativas no solo se evidenció que los estudiantes en formación percibían como "normal" que la docente, a quien observaban, enseñara las vocales y el alfabeto por fuera del contexto, que exigiera a los niños y niñas de 5 y 6 años estar inmóviles en el escritorio y hasta que en clase de artes limitara su imaginación cuando entregaba una flor a los pequeños y señalara los colores exactos que debían utilizar.

La segunda parte del libro es una reconstrucción de las condiciones socio históricas en las que emerge la necesidad explícita de educar para la democracia y la ciudadanía en Colombia. Es el producto de una investigación que se llevó a cabo en tres instituciones educativas de los municipios de Ansermanuevo, Cartago y Pereira. Se prendía responder a la pregunta ¿Cómo y en qué momento emerge la necesidad de democratizar la escuela colombiana? y se propuso como objetivo, analizar las condiciones socio-históricas en las cuales irrumpe la necesidad de democratizar la escuela en Colombia. 
Se utilizó el análisis documental, para establecer las condiciones en que emergió el proyecto democratizador de la escuela en Colombia, interesaba especialmente establecer qué condiciones sociales dieron vida al tema y los discursos y las concepciones que existían en el momento sobre los jóvenes estudiantes y la educación. Se realizó una revisión de documentos de la legislación escolar que fueron registrados en tarjetas o fichas de trabajo con información como el título, carácter del documento, denominación, autor y destinatario, origen, periodicidad, procedencia y fecha de producción, el contenido, su dirección y su orientación. Las fichas de trabajo fueron útiles para registrar datos indispensables como ideas, juicios, lugares, cifras, fechas. Con las fichas se pudo establecer motivaciones del autor o las situaciones en que se produjeron los documentos y su historia. Dentro del análisis se resaltaron palabras, líneas, párrafos, intervenciones de sujetos, temas, descripciones, frecuencias, significados, relaciones de categorías, eventos, situaciones, que permitieron hallar correlaciones de las categorías de análisis con los documentos.

El eje articulador de las dos partes del libro además de ser la educación infantil, es el clima de reformas educativas que se inician en toda América Latina y Colombia desde los años 70, se amplía en los 80 , se consolida en los 90 y se mantiene hasta hoy; el volcamiento de la mirada a la educación inicial, las reformas del componente pedagógico (primera parte del libro) y la democratización, (segunda parte del libro) son objetivos centrales de las reformas en cuestión. Las reformas se produjeron en el contexto de un clima de transformación de todos los órdenes de la vida social en el mundo y en América Latina; desde la perspectiva de Piñón (1998):

[...] la intensidad de las modificaciones sociales cuestionó los patrones de desarrollo vigentes y las formas organizativas, que inciden en el mundo del trabajo y la producción y que, por ende, implican el desafío para los países de insertarse en forma protagónica en la nueva realidad. (p.1).

Las transformaciones sociales planteaban nuevas y mayores exigencias a la educación, esta debía ponerse en el centro de la vida social y constituirse como el motor de desarrollo y progreso, Susana Beatriz (1996), lo anunció con estas palabras: "la educación es la herramienta más importante que tienen la sociedades para orientar la historia en este fin de siglo" (p.64). Es por eso que el libro recoge reflexiones alrededor de algunos aspectos que fueron motor de la reforma: más concretamente de dos, el mejoramiento de la calidad de la educación y la necesidad de consolidar la democracia, la participación y la convivencia en la región. Para ambos anhelos era necesario, entre otras acciones, mejorar los procesos enseñanza y el aprendizaje, 
rediseñar los currículos, fomentar estrategias pedagógicas innovadoras. Tanto el proyecto democratizador de la escuela como, el ascenso de la importancia de la primera infancia, y la necesidad de replantear los procesos de enseñanza de la lectura y la escritura hacen parte de los que Navarro (2006) denomina el activismo reformista de la educación, entendido como un gran acuerdo social sobre la necesidad e incorporar al sistema educativo a todos los niños y jóvenes y de lograr que su estadía en el sistema educativo sea cada vez, más significativa y prolongada.

En los años 70 las reformas se centraron en modificaciones curriculares y en la reorganización administrativa de los organismos que rigen los sistemas educativos de los países, fueron orientadas y coordinadas por organismos de planeamiento, que asumieron dicha responsabilidad aplicando los criterios conceptuales y las metodologías que les eran propios; debido a que las reformas no incluían las posibilidades de participación de los docentes, falta de precisión en la determinación delos proyectos y acciones específicas a desarrollar yla inexistencia delos mecanismos e instrumentos y de control de ejecución que se requerirían para su implementación, provocan fuertes resistencias por parte de diversos sectores profesionales y sociales (Michel, 2004, p. 80). En los 80 las reformas se enfocan en la ampliación de la cobertura educativa, y la descentralización, hay cambios significativos en la forma de entregar servicios sociales y educativos desde el gobierno central, de manera que la educación sea administrada y gestionada por las provincias, las comunas y sectores privados; estas reformas se acompañan de un repliegue en el aparato público y la reducción del gasto en educación (Guzmán, 2005, p. 1).

En los años 90 bajo la influencia del Banco Mundial se utiliza el análisis económico para determinar las prioridades educacionales, se propician reformas orientadas a renovar la inversión en el talento humano, establecer normas y medir el rendimiento mediante evaluaciones del aprendizaje, ampliar la cobertura escolar (Michel, 2004: 85). Estas reformas pueden agruparse en cuatro ejes: gestión, equidad y calidad, perfeccionamiento docente, y financiamiento. Cada una de ellos tiene estrategias y programas; entre los relacionados con las referidas en el libro podemos mencionar: reformas curriculares, programas de mejoramiento e innovación pedagógica, fortalecimiento de la autonomía escolar y promoción de la participación familiar en la educación y en la enseñanza, prioridad a la educación inicial, fortalecimiento de los aprendizajes de la escritura y las matemáticas, formación de una ciudadanía para la construcción de democracias abiertas y participativas. En síntesis, este libro no solo está a la vanguardia, sino que, además, supone aportar a la educación en Colombia y en el mundo toda vez que permite comprender la ciudadanía, el ser sujeto político y propone otras prácticas y discursos pedagógicos que atienden a las exigencias educativas y sociales actuales. 
CAPÍTULO I 



\title{
DESAPRENDER NO ENSEÑAR COMO APRENDIMOS
}

\author{
Consuelo Orozco Giraldo
}

\section{TENDENCIAS Y COMPRENSIONES LINGÜÍSTICAS: VIGENCIA Y NO NEUTRALIDAD}

Al solapar las diferencias entre los hombres o al hacerlas secundarias, la educación se torna en escenario de fórmulas universales detrás de las cuales es posible identificar un cierto biologismo sin tomar en consideración las profundas diferencias surgidas de contextos distintos, lenguas distintas, construcciones políticas y económicas distintas que no permitirían legitimar una concepción universalista del ser humano más a la de su aspecto biológico.

Los ingentes esfuerzos de los últimos años y la inversión en beneficio de la educación son evidentes, sin embargo, para solucionar las dificultades educativas no es suficiente la inversión económica sin prestar atención a "la forma" en que la educación es impartida, en otras palabras, vigilar la "inversión” y no los resultados "reales", es un engaño que la sociedad y la educación están pagando con intereses de usura, es cuando los falsos positivos en el plano educativo entran en escena.

El protagonismo del lenguaje en general y en la educación en particular, ha sido un tema de múltiples investigaciones en numerosas ocasiones. El lenguaje, lejos de ser un invitado fantasma en el campo educativo debe ocupar un lugar central porque es la herramienta por excelencia que, entre otras cosas, nos permite movilizar pensamiento. A través del lenguaje nos comunicamos, nos acercamos a los demás, 
lo comprendemos, compartimos experiencias y construimos mundos. De la misma forma que la educación representa la herramienta más eficaz para combatir la violencia, la desigualdad y todas las situaciones que aquejan a nuestra sociedad, el lenguaje aporta, en gran medida, a la solución de cualquier clase de conflictos, especialmente aquellos gestados en la familia y que por falta de comunicación o buen uso del lenguaje, trascienden a la sociedad convirtiéndose en actos violentos de toda índole.

Que somos lenguaje, respiramos lenguaje y pensamos con el lenguaje, son claridades que le debemos al giro lingüístico gestado por Nietzsche. Desde entonces, comprendemos que no es posible homogenizar o neutralizar las estrategias pedagógicas como tampoco se podría hacer con el lenguaje, porque vivimos un mundo que lejos de ser plano, se caracteriza por ser curvilíneo y asimétrico. Sabemos que los humanos han logrado comunicarse entre sí utilizando un enorme conjunto de lenguas y símbolos, pero, ¿qué tan fiel es la información cuando llega al receptor? ¿Acaso el mensaje no está mediado y filtrado por otros sistemas de significación diferentes al emisor y al receptor que si bien comparten contextos semánticos también tienen contextos propios? El ser humano, lejos de ser uno, es muchos a la vez, son "yoes" de turno que le permiten jugar diferentes roles aun en el mismo cuerpo físico. Somos padres, hijos, hermanos, amigos, ciudadanos cada uno de esos roles exigen que nuestros comportamientos y emociones muten dependiendo del "yo de turno". En el caso de los pequeños en la primera infancia, pensar el lenguaje resulta determinante porque es la herramienta a través de la cual ingresamos a sus pensamientos y a sus emociones.

Creer en la eficacia del lenguaje plano y de una "personalidad" es un engaño gestado, entre otros, por Platón y Aristóteles cuatro siglos antes de Cristo. A estos pensadores de la antigua Grecia debemos el protagonismo del lenguaje plano, libre de metáforas e ironías, la mayoría de las taxonomías sociales y la educación tradicional, repetitiva y bancaria (Freire) que coloniza la educación actual. Aunque se ha comprobado que con el estilo plano propio de la educación tradicional se llega a más estudiantes porque todos escuchan al profesor, no menos cierto es que las prácticas pedagógicas planas y un lenguaje plano sacrifica las compresiones de los estudiantes cuando no la posibilidad de conectarse emocionalmente con los contenidos. Que las prácticas pedagógicas tradicionales hayan hecho carrera y mantengan su vigencia, es un error que los docentes perpetuamos al conservar nuestra zona de confort y educamos en lo racional por fuera de lo emocional (Maturana), entrenando estudiantes del siglo XXI con estrategias de siglos antes de Cristo, no es otro el desfase que pagan con creces el lenguaje, la educación y la sociedad actual. 
Muchos son los discursos y prácticas pedagógicas, algunas afortunadas (Socioconstructivismo) otras no tanto (Conductismo), tarea inaplazable es identificar aquellas que respetan las diferencias que han sido objeto de investigación en tantas ocasiones y que dan la pista de un ser humano plural, con una combinación de emociones y cogniciones que lo hacen único e irrepetible, con percepciones del mundo mediadas por el lenguaje y por el contexto. La era de la globalización trae consigo el fantasma del universalismo y supone la unificación del lenguaje, cuando no del pensamiento. Traductores simultáneos, intercambios culturales sincrónicos o información ilimitada supone el mundo a nuestros pies, sin embargo, muchos discursos y prácticas pedagógicas se mantienen al margen de los mencionados cambios y continúan comprendiendo el lenguaje por fuera del contexto y a la educación por fuera de las emociones.

Que las abismales diferencias entre el mundo de las ciencias exactas y el de las humanidades se hayan olvidado, es otro artificio de la filosofía platónica que la globalización parece reforzar. Al quitarnos las vendas del universalismo nos damos cuenta que las TIC abren caminos en lugar de cerrarlos, todo dependería de su uso y la capacidad de "aduana" de quienes trabajamos la educación.

El lenguaje plano propio de las ciencias naturales y exactas, permiten comprender los hechos naturales como el día, la noche o la fuerza de gravedad, hechos que al ser predecibles e inclusive comprobables (Popper), son categorizados como universales. Sin embargo, no sucede lo mismo con las humanidades, no es posible saber con certeza lo que va a suceder, lo que una persona siente, piensa o como va actuar frente a una situación dada. Mientras el mundo de las ciencias exactas es objetivo, el de las humanidades es subjetivo. Tratar a los estudiantes como objetos medibles o predecibles es el pecado capital que la educación esta perpetuando y que continuará haciendo mientras ignoremos la importancia del contexto en los actos de habla y utilicemos "formulas" que funcionen para todos y en todos los casos. La comprensión del lenguaje y los procesos de lectura y escritura en la primera infancia no son ajenos a las mencionadas vicisitudes.

Los límites del lenguaje son los límites del mundo, de acuerdo con Wittgenstein, de ahí la urgencia del lenguaje metafórico que amplía los horizontes de comprensión porque incita a pensar, a imaginar, a movilizar, a probar y a tomar el riesgo. No es otra la querella educativa cuando encuentra la siguiente bifurcación: el lenguaje plano (libre de metáforas e ironías) que llega a muchos, pero perdura poco, o el lenguaje poético que puede llegar a menos personas pero que se implanta en sus emociones alargando la vida del conocimiento en la memoria. 


\subsection{Pragmática Lingüística}

A lo largo de la historia han sido numerosas las ciencias que se han interesado por entender la forma como se da y los elementos que están presentes en la comunicación humana, una de las más enfocadas es la pragmática lingüística, sin embargo, para adentrarnos en lo que es, cómo funciona, por qué es importante y qué elementos o actos la determinan, es necesario reflexionar un poco más sobre cada una de ellas para lograr entender las mágicas y por suerte inevitables confluencias que entre ellas existen y que se nutren en el acto comunicativo.

La pragmática se interesa por analizar cómo los hablantes producen e interpretan enunciadosencontexto; deahíque tomeen consideraciónlosfactores extralingüísticos que determinan el uso del lenguaje, a los que no puede hacer referencia un estudio puramente gramatical, entre otros, los interlocutores, la intención comunicativa, el contexto o el conocimiento del mundo. En otras palabras, la pragmática es la capacidad de comunicarse más allá de lo que se indica explícitamente, es reconocer o por lo menos sospechar la intencionalidad del otro, en síntesis, es preguntarse por lo que alguien me ha "querido decir", más que por "lo que me ha dicho".

En el análisis pragmático se analizan diferentes variables relevantes para la comprensión de un enunciado o para explicar la elección de determinadas formas superficiales para realizar el enunciado en función de los factores contextuales. Entre las variables más relevantes están: la situación, el lugar, el tiempo donde ocurre el discurso, el contexto socio-cultural que tienen en cuenta costumbres y creencias que son de relevante importancia a la hora de emitir un discurso, las personas presentes producto de dicha cultura y el tipo de relación que con ellas se mantenga.

De este modo, la pragmática analiza porqué el destinatario de un enunciado puede interpretar tanto y de tantas formas según sea el conocimiento del mundo y las estructuras cognitivas (Piaget) de dicho destinatario. En este sentido, se dice que los interlocutores poseen información pragmática, entendiendo como tal el conjunto de conocimientos, creencias, supuestos, opiniones, etc. de un individuo en una interacción concreta, lo que determina las formas como recibe y comprende los mensajes.

Si bien está generalmente admitido que entre los precedentes más remotos de la pragmática se encuentran los antiguos retóricos, la acuñación del término se debe a C. Morris, en los años 30 del siglo XX. Con él, designó la ciencia de los signos en relación con sus intérpretes. Este autor clasifica la pragmática como una disciplina 
lingüística, junto con la semántica y la sintaxis. Sin embargo, actualmente la pragmática ha dejado de plantearse como un módulo más del análisis lingüístico para convertirse en una perspectiva diferente de acercarse a los fenómenos lingüísticos de cualquier nivel siempre que se tengan en cuenta los factores contextuales que incluyen como lo había mencionado anteriormente las personas, la relación que con ellas se tenga y la información.

Una de las líneas de investigación pragmática más importante dentro del pensamiento contemporáneo es la iniciada por Austin quien a través de los actos de habla deja comprender que no siempre decimos es lo que queremos decir toda vez que el contexto juega un papel determinante. Para Austin, el acto de habla tiene tres niveles, o se realiza a través de tres actos conjuntos: el acto locutivo, que consiste meramente en enunciar la frase en cuestión; el acto o fuerza ilocutiva, que consiste en levar a cabo algo a través de las palabras (prometer, amenazar, jurar, declarar, este empezaría ser el componente implícito); y el acto o efecto perlocutivo, que consiste en provocar un cambio en el estado de cosas o una reacción en el interlocutor. Con Austin se da un giro pragmático al acto comunicativo en donde el lenguaje asume carácter de acción "decir algo es hacer algo", ejemplo: "tráeme el vaso". Leemos en Cómo hacer cosas con palabras

Cuando alguien dice algo debemos distinguir: a) el acto de decirlo, esto es el acto que consiste en emitir ciertos ruidos con cierta entonación o acentuación [...] acto ilocucionario, o la dimensión locucionario del acto lingüístico; b) el acto que llevamos a cabo al decir algo: prometer, advenir, afirmar, felicitar, [...] acto ilocucionario [...]. c) el acto que llevamos a cabo porque decimos algo: intimidar, asombrar, convencer, ofender, esto es acto perlocucionario (Austin, 1971, p. 32).

Aunque se presentan de manera simultánea, las propiedades de los tipos de enunciado son diferentes. Si el acto locutivo posee significado; si el acto ilocutivo permite coordinar acciones; y si el acto perlocutivo logra efectos; los actos de habla se podrían resumir en dos frases: en virtud del protagonismo del contexto (con el lenguaje no solo se describe el mundo sino que, se hacen cosas) y las oraciones (aunque compartan el contenido proposicional pueden significar cosas en virtud de su fuerza, efectos y consecuencias).

Nadie discutela existencia de los enunciados perlocucionarios que fueron formulados por Austin en Cómo hacer cosas con palabras. Que las palabras no solo dicen, sino que, además, motivan enojan, despiertan, agreden, no está en discusión. Formular 
un listado de los verbos perlocucionarios como hace Austin, puede resultar un resabio lingüístico, cuando la pragmática nos enseña que los enunciados que en un contexto son perlocucionarios, en otro pueden ser simplemente locucionarios.

Si el lenguaje es más que sonidos, reglas gramaticales y palabras, si los contextos construidos y compartidos entre emisor y receptor favorecen la trasmisión del mensaje y determinan en gran medida las consecuencias de los actos de habla, la pragmática lingüística permitiría entender lo dicho (lo que el emisor quiere decir) y lo trasmitido (lo que el receptor comprendió). La pragmática libera al lenguaje de la neutralidad y permite que el significado de las palabras dependa de su relación con los hablantes y los contextos, con la cultura y todo lo que ella le permite comprender.

Que no siempre nuestras palabras digan lo que queremos decir, que la cercanía entre lo que quiero decir y lo que los demás entienden, dependa del contexto, demuestra que la pragmática nos hace menos ingenuos frente al lenguaje. La lingüística por su parte, es la ciencia que estudia el lenguaje. Puede centrar su atención en los sonidos, las palabras y la sintaxis de una lengua concreta, en las relaciones existentes entre las lenguas, o en las características comunes a todas ellas. En este punto tendríamos que preguntarnos ¿qué relación tiene la realidad con el contexto? ¿Depende el contexto de la realidad o la realidad del contexto? ¿Es acaso el lenguaje el resultado de la interacción entre estos? ¿Por qué son ignoradas las bondades de las interacciones orales de los niños?

Si las palabras no solo dicen, sino que, hacen, si el contexto cobra protagonismo, es menester que la academia adelante un giro que recupere la centralidad del lenguaje, no solo por su poder para hacer, sino, además, por sus múltiples connotaciones individuales y sociales. Leemos en Emociones y lenguaje en educación y política de Maturana:

Necesito mi cerebro para estar en el lenguaje, tengo un cerebro que es capaz de crecer en el lenguaje, pero el lenguaje no se da en el cerebro. El lenguaje como fenómeno, como un operar del observador, no tiene lugar en la cabeza, ni consiste en un conjunto de reglas, sino que tiene lugar en el espacio de relaciones y pertenece al ámbito de las coordinaciones de acción como un modo de fluir en ellas, no como algo en citas. Si cambia mi estructura, cambia mi modo de estar en relación con los demás y, por lo tanto, cambia mi "lenguajear". Si cambia mi "lenguajear", cambia el espacio del "lenguajeo" en el cual estoy y cambian las interacciones en que participo con mi "lenguajeo" (Maturana, 1990, p. 29). 
Reflexionar sobre el lenguaje, es estar en él. Sabemos que el mundo ha cambiado, que hay apuestas y no caminos ni certezas, que la emoción hace parte de las funciones de nuestro sistema nervioso; de ser reprimida, quedamos sin motivación, desmejorando la memoria, si no es que la desparece. Reconocer el poder de la emoción en la memoria, y la contingencia del mundo actual, resulta perentorio. El conocimiento debe motivar para no terminar olvidado. Si los niños son emoción y alegría, ¿por qué despojarlos de lo que han sido dotados por naturaleza?

La forma como Austin nos presenta la pragmática lingüística obligaría a los profesionales de la educación a cuestionar sus prácticas pedagógicas, y preguntarnos ¿estamos encantando y provocando el aprendizaje o solo estamos transmitiendo contenidos? ¿Estamos respetando los estilos de aprendizaje? ¿Conocemos las necesidades e intereses de los niños o estamos estandarizando nuestra práctica? ¿Es nuestro estilo plano o poético? ¿Estamos utilizando la metáfora como estrategia mediadora y eficaz en el aprendizaje y en general en las ciencias humanas? ¿Es la pragmática lingüística parte de nuestra formación y discurso pedagógico?

Si las conversaciones son inherentes al contexto, la pragmática lingüística parece estar en una ardua y contante lucha con el estilo plano, mientras en el primero actúa como antagonista, el segundo es protagonista, por lo tanto, el primero es expulsado. Sentimientos, culturas, costumbres y predisposiciones de las personas, harían que nos ocupemos de una pragmática lingüística que atienda y comprenda la pluralidad humana en especial la infantil dadas las condiciones y predisposiciones que para el aprendizaje poseen los niños.

\subsection{Relatividad Lingüística}

La relatividad lingüística afirma que lenguas distintas llevan consigo formas de pensar diferentes; y que sus correspondientes hablantes conciben el mundo, lo piensan, de maneras también distintas, por eso al pensar en relatividad lingüística, pronto viene a nuestro pensamiento los léxicos y las gramáticas, las lenguas y los idiomas y es precisamente esta relatividad la que nos permite no solo explorar las formas como los diferentes idiomas funcionan, sino, además, que el contexto como ya se ha mencionado, tiene un lugar predominante y decisivo. Porque los léxicos y las gramáticas no son neutrales, cada uno de ellos obedece a variedades cultuales y contextuales, como lo podemos evidenciar en el siguiente aparte: 
Desde finales de la década de 1980, los integrantes de una nueva escuela de relatividad lingüística, basados en los avances en el área, han examinado los efectos de las diferencias de la categorización lingüística sobre el razonamiento encontrando un extenso soporte para la hipótesis en contextos experimentales. Los efectos de la relatividad lingüística han sido mostrados especialmente en el campo de la cognición espacial y en el uso social de la lengua, pero también en el campo de la percepción del color. Estudios recientes han demostrado que la percepción del color es particularmente propensa a los efectos de la relatividad lingüística cuando es procesada en el hemisferio izquierdo del cerebro, sugiriendo que esta parte del cerebro depende más del lenguaje que el lado derecho. Actualmente una vista equilibrada de la relatividad lingüística es apoyada por muchos lingüistas sosteniendo que influye en ciertos procesos cognitivos en caminos no triviales pero que los otros procesos son mejor vistos como sujeto de factores universales. La investigación actual está concentrada en explorar los caminos en los cuales el lenguaje influye en el pensamiento y hasta qué punto (Verspoor, 2000, p. 17).

De esta forma, las lenguas canalizan la experiencia y por lo tanto, el contexto y la realidad del individuo o el grupo de individuos que comparten la lengua, lo que pondría en tela de juicio el pensar la comunicación, los léxicos y las gramáticas como neutrales.

La educación infantil, no ha sido ajena a la "falsa neutralidad" del lenguaje y a las taxonomías no solo lingüísticas, sino, además, pedagógicas. La fragmentación de los procesos de lectura y escritura son prueba del pecado capital que se está cometiendo con los niños y niñas porque separamos lo que por naturaleza está unido: pensamiento-lenguaje, teoría-práctica, niñez-imaginación. Fue precisamente Piaget quien a través de la teoría de la equilibración permite comprender que los seres humanos en general y los niños en particular, comprenden el mundo haciendo uso de los recursos cognitivos, es decir, con lo que cuenta en su cerebro. Si mostramos por ejemplo la letra $\mathrm{m}$ a un pequeño cuando inicia su proceso de lectura y escritura, ¿qué conocimientos previos podría utilizar para comprender la letra e internalizarla? Básicamente ninguno por dos razones contundentes: en primer lugar, porque las letras no son naturales, son una construcción social que el hombre inventó, entre otros, para comunicarse. En segundo lugar, porque esa letra (m) está por fuera de contexto, es decir, que no está ubicada en una situación "real" o por lo menos familiar para el pequeño, razón por la que cada vez que el pequeño 
memoriza una letra aumenta las prótesis intelectuales que terminan cayéndose casi siempre cuando más se necesitan.

Los lineamientos curriculares de lengua castellana publicados por el Ministerio de Educación Nacional colombiano, resultan ser de gran utilidad cuando de pragmática lingüística se trata, pero especialmente cuando se ubica en el plano infantil. En este documento, el Ministerio acude a grandes pensadores del lenguaje, algunos clásicos como Piaget, Vygotsky y otros más recientes como Emilia Ferreiro, Liliana Tolchinski y Ana Teberosky. El objetivo fundamental del documento cuando de acompañar los procesos de lectura y escritura en la primera infancia se trata es enseñar palabras completas a través de la literatura, en otras palabras, que los niños lejos de aprender letras libres de contexto, interactúen con palabras con sentido completo. Leemos en los mencionados lineamientos:

[...] los trabajos de Emilia Ferreiro, Liliana Tolchinski, Ana Teberosky, Gloria Rincón y Olga Villegas son un referente obligado. Según estas investigaciones, el manejo del código alfabético convencional es un punto de llegada y no un punto de partida en el desarrollo natural de la significación en el niño. Por tanto, los enfoques que toman como punto de partida el fonema, la sílaba y la palabra, poniendo el énfasis en la relación sonido/grafía, no son pertinentes como iniciación a la escritura. En este sentido, resulta necesario generar espacios de significación en los que la escritura cobre sentido social, y el problema de la fonetización y el acceso al código alfabético serán una necesidad que aparece de manera natural (MEN, 1998, p. 53).

Es así como antiguas metodologías que tienen como punto de partida las vocales, letras y sílabas han quedado obsoletas, no solo por la falta de sentido y coherencia con la vida natural de los niños, sino, además, porque los despoja de la posibilidad de pensar y construir significados a partir de sus presaberes, entrenándolos para la automatización y repetición del sinsentido (la $\mathrm{m}$ con la a, ma. Realmente, sería emea). La pragmática lingüística sería la clave para desarrollar habilidades trasversales y hacer niños felices, con altos niveles de autoestima. Si en lugar de enseñar la m y luego la a enseñáramos la palabra mamá, los conocimientos previos de los niños como lo que es una mamá, qué hace una mamá, quién es su mamá tomarían importancia. En síntesis, los niños a lo largo de su vida han construido conceptos de diferentes niveles de complejidad, el trabajo de la docente solo sería brindarle las palabras que representan esos conceptos. 


\section{DESFRAGMENTACIÓN EN LA PRIMERA INFANCIA, TAREA DE TODOS}

\subsection{Lenguaje, lectura y escritura en la primera infancia}

Surgido con fines de supervivencia, el lenguaje es el resultado de una invención humana y evolución natural y cultural de millones de años. La escritura alfabética, lejos de ser ajena a la mencionada evolución, sería la más evidente prueba de la genialidad humana cuando inventa nuevas formas de comunicarse. Este aparte del libro pretende, de un lado, desenmascarar algunas prácticas y discursos pedagógicos tradicionales que disfrazados de oveja, terminan devorando, entre otras cosas, la imaginación infantil eliminando toda posibilidad de pensamiento divergente porque unifica lo que por naturaleza es plural, y del otro lado, compartir hallazgos investigativos de carácter teórico que dan cuenta no solo de las tendencias e los enfoques pedagógicos actuales, sino, además, de la importancia de un adecuado acompañamiento a los procesos de lectura y escritura en la primera infancia.

Que procesos determinantes como la lectura y la escritura pasen de largo, resulta "natural" en una sociedad gobernada por la tecnología y por el cambio a la velocidad del vértigo. Si no hay persona "alfabetizada" ni profesional que no haya pasado por manos de un docente que le enseñó a escribir y a leer ¿por qué la educación en la primera infancia ha desempeñado un papel secundario cuando no antagónico? No pretendemos insinuar que la educación básica, media y superior carezcan de importancia, lo que pretendemos desentrañar y hacer consciente es que la calidad de la educación que reciben nuestros pequeños, determinan en gran medida, sus procesos cognitivos y emocionales en el futuro, lo que demandaría que nos ocupemos de ella, la repensemos o por lo menos pongamos en tela de juicio ciertas estratagemas que la han colonizado y que lejos de permitirles avanzar, los relega a la mera repetición de las letras. Repensar el rol del maestro como agente cognoscente y del estudiante como agente ignorante en el proceso educativo, resulta inaplazable. Leemos en Pedagogía del oprimido:

En la visión "bancaria" de la educación, el "saber", el conocimiento, es una donación de aquellos que se juzgan sabios a los que juzgan ignorantes. Donación que se basa en una de las manifestaciones instrumentales de la ideología de la opresión: la absolutización de la ignorancia, que constituye lo que llamamos alienación de la ignorancia, según la cual ésta se encuentra siempre en el otro (Freire, 1970, p. 52). 
Al igual que Freire se ocupó de una pedagogía de la liberación para la educación en general, muchos han sido los esfuerzos de algunos estudiosos de la primera infancia por exhortar a la adopción de nuevas teorías y estrategias que permitan a los niños cruzar esta importante pero ardua senda. Ocuparnos de ellos y proponer otras opciones que brinden protagonismo al lenguaje infantil y a las formas como orientamos los procesos de lectura y escritura en la primera infancia, resulta determinante.

Para lograr que los lectores de éste libro repiensen sus prácticas y en lo posible, adopten otras estrategias contemporáneas que respeten y comprenden la naturaleza infantil y todas sus connotaciones, nos proponemos en lo que resta de éste libro, entre otras cosas, adelantar teóricamente tres categorías fundamentales que permitirán: ser menos ingenuos frente las prácticas disueltas en la primera infancia, en el primer caso; identificar algunos de los postulados teóricos que fortalecerán los discursos y prácticas pedagógicas en la primera infancia, en el segundo caso y finalmente, compartir algunas tendencias teóricas actuales que al ser resultado de una investigación que al iniciar en lo práctico y finalizar en lo teórico, aportan a la comprensión sobre las mejores formas de acompañar los procesos de lectura y escritura en la primera infancia.

\subsection{Pasado-presente y presente-futuro de la educación infantil}

Heredado de la antigua Grecia, el statu quo que ilustra sobre la forma de orientar la lectura y la escritura en la primera infancia mantiene su vigencia. Aunque equivocado y desactualizado para los niños y niñas actuales, la falta de claridad del sistema educativo, en concierto con la incompetencia de algunos profesionales que lo componen hace que aún esté siendo aplicado sin beneficio de aduana.

De acuerdo con el statu las personas tienen un tipo de alma (Platón), la educación debe entrenar con fines políticos y a través de un solo Método con mayúscula, ésta aseveración ha hecho de la educación actual su más ferviente seguidora. Aplicar ciertas estrategias pedagógicas heredadas de la antigua Grecia es darle vigencia al pasado (pasado-presente), adoptar nuevas estrategias acordes a las exigencias de la sociedad y los estudiantes actuales (presente-futuro), resulta inaplazable.

Con la idea de educar para formar almas integras que se dediquen a aquello para lo cual nacieron, Platón sentó las bases sobre las cuales el sistema educativo actual está sustentado. Su interés por el dominio de la educación se hace evidente cuando en La República, tal vez su más importante escrito, se ocupa de dar pautas precisas 
y maniqueístas para educar en la edad más tierna, dejando a los pequeños sin posibilidades de fantasear. Lejos de educar para la cohesión social y la Eudaimonía, la política educativa del seguidor de Sócrates se dedica a entrenar para la política, para la guerra y de acuerdo al tipo de alma:

Acuérdate también de que, según dijimos antes, es preciso llevar a los niños a la guerra a caballo, hacer que presencien el combate, y hasta aproximarlos a la pelea cuando no haya en ella gran peligro, y procurar en cierta manera que gusten la sangre como se hace con los perros jóvenes de caza.

- Me acuerdo de eso.

Pondrás a un lado los que hayan mostrado más paciencia en los trabajos, más valor en los peligros y más ardor en las ciencias (Platón, 1966, p. 249).

Tomada de Orfeo la idea de alma, y habiendo tres tipos de ella para Platón: alma concupiscible, alma irascible y alma racional, habrá tres tipos de hombre según predomine la una o la otra en cada uno: la producción material, las necesidades básicas humanas como el placer y la alimentación estarían presentes especialmente en quienes predomina el alma concupiscible; la voluntad, la fortaleza y el valor para la guerra, en quienes predomina el alma irascible y gobierno, la inteligencia y la sabiduría, en quienes predomina el alma racional, de naturaleza divina, eterna e inmortal. Señalado el tipo de alma, no habría manera de cambiarla.

Aristóteles al igual que su maestro Platón, también valoró la importancia del ámbito del juego, en los más pequeños, sin embargo, lejos de ser libre, la educación en la primera infancia en general y el juego, en particular, debían estar destinados a formar para la sociedad y a forjar las habilidades de acuerdo al tipo de alma y a la edad. Antes de los cinco años, los niños no estarían en capacidad de hacer operaciones intelectuales. Leemos en La Política de Aristóteles:

Todos los hábitos que deben contraer los niños, conviene que comiencen desde la más tierna edad, teniendo cuidado de proceder por grados [...]. En cuanto a la edad que sigue a ésta y que se extiende hasta los cinco años, no se puede exigir ni la aplicación intelectual. [...]. Todo esto debe hacerse a fin de prepararles para los trabajos que más tarde les esperan; y así sus juegos deben ser en general ensayos de los ejercicios a que habrán de dedicarse en edad más avanzada (Aristóteles, 1988, p. 158). 
Sin un juego libre que permita a los pequeños expresarse, las posibilidades de observar, inventar, investigar y comprender lo relacionado con su entorno de manera espontánea, queda sin posibilidades. Si el juego no solo es natural en los niños, sino que, además, desarrolla su inteligencia (cuando asimila de acuerdo con Piaget), la educación que proponen Platón y Aristóteles para la primera infancia, no solo ignora su condición natural infantil, sino, además, su capacidad para aprender y explorar el mundo. Tales aseveraciones se pueden evidenciar en muchas prácticas pedagógicas actuales que evitan el juego y centran sus esfuerzos en hacer del acto educativo un suplicio obligatorio, Platón y Aristóteles estarían felices de ver perpetuado su maniqueísmo:

Se convendrá sin dificultad en que la instrucción que se da a los jóvenes no es cosa de juego. Instruirse no es una burla, y el estudio es siempre penoso. Añadamos que el ocio no conviene durante la infancia, ni en los años que siguen (Aristóteles, 1988, p. 166).

Una educación penosa y libre de diversión en general y en la primera infancia en particular, parece haberse inmortalizado. Toda clase de apuestas a través de la historia han aportado a la comprensión del desarrollo humano algunas poco afortunadas como el genetismo quien dejaba el desarrollo infantil a merced de la información genética, en otras palabras, el nivel de desarrollo infantil está determinado por la herencia (Bacon), sin embargo, ésta teoría fue puesta en tela de juicio gracias a una corriente psicológica que con vestigios Metafísicos seguramente heredados de Platón y Aristóteles, apostaron por el estudio de la conducta observable esperando controlarla y predecirla, solo lo observable, de acuerdo con el conductismo, es digno de estudio y comprensión.

\subsection{Paradigma Conductista: el aprendizaje como cambio de conducta}

Con tintes vitalicios, el conductismo se ha mantenido vigente durante muchos años a pesar de su desajuste con los nuevos paradigmas educativos, su concepción del aprendizaje como mecánico, deshumanizado y reduccionista, así lo revelaría. Que en la actualidad se prepare por unidades de información (a manera de estímulo) que existan pruebas y actividades prediseñadas y estandarizadas, es decir, libres de contexto, evidenciaría no solo la respuesta que se espera del estudiante, sino, además, la presencia del conductismo en la educación actual.

Considerados como los grandes teóricos del conductismo Pavlov (1885) Watson, J.B. (1913); Thorndike, E.L. (1913) y Skinner, B.F. (1965), marcaron un hito en la 
historia de la educación. Centrado exclusivamente en las conductas observables y en sus cambios mediante Estímulo - Respuesta (conductismo clásico) o Refuerzos Positivos o Refuerzos Negativos (conductismo operante o instrumental), su postura se convirtió en un "modelo a imitar" por aquellos que decidieron satanizar o ignorar, en el mejor de los casos, los sentimientos, las emociones y el pensamiento, los mismos que hoy demandan su protagonismo en el aula de clase y en la vida humana en general.

Ignorado el pensamiento, el lenguaje y las emociones inclusive por carecer de materia, el ser humano es unificado y la educación uniformada. No es otro el objetivo del conductismo cuando da protagonismo a las conductas observables en detrimento de aquellas que aunque carecen de materia nos mueven con increíble facilidad. Esa ignorancia de los sentimientos y las emociones, se hace evidente en Sobre el conductismo (1974), uno de los escritos más importantes de Skinner (1974), en donde es posible leer "He destacado la diferencia entre los sentimientos y el informe de lo que se siente. Podemos suponer que el sentimiento es simplemente responder a estímulos" (p. 36). Que los sentimientos se reduzcan a la simple respuesta de un estímulo, evidencia la concepción de estirpe platonicoaristotélica que subyace en el conductismo, lo que permite inferir que el aprendizaje, desde este punto de vista, se reduce a Refuerzos Positivos o refuerzos Negativos y que una ráfaga de estímulos positivos bastarían para que se recuerden los contenidos. Leemos en Sobre el conductismo:

El comportamiento se fortalece por sus consecuencias y por esta razón a las mismas consecuencias de las llama "reforzadores", así pues cuando un organismo hambriento exhibe un comportamiento que produce alimento, las consecuencias refuerzan el comportamiento y, por tanto, éste tiene mayor probabilidad de volver a ocurrir (Skinner, 1974, p. 36).

No es otro el engaño al que son sometidos los estudiantes en la actualidad a pesar de los avances y postulados teóricos que dan cuenta de otras formas de aprender que lejos de la manipulación sin sentido que propone el conductismo, asume posturas en las que el estudiante se comprende como un ser integral con cogniciones y desarrollos propios, en síntesis, el protagonista en el acto educativo. Sin embargo, resulta determinante aclarar que mientras las prácticas y discursos pedagógicos no estén permeadas por la alegría y la claridad de los contenidos, estudiantes y maestros continuarán necesitando del conductismo para funcionar por los menos a escala básica: los estudiantes para no pensar y los docentes para evitar pensar, lo que "facilitaría su trabajo" (la pluralidad estudiantil implicaría más trabajo). Caritas 
felices y tristes, buenas y malas notas o espacios determinados en el aula de clase, son la prueba de que el conductismo continúa colonizando las aulas de clase, incluso en la primera infancia. Es así como éste tipo de mayéutica vergonzante hace que los deseos naturales de los pequeños por jugar, moverse, preguntar y socializar resultan gravemente lesionados.

De espalda al conductismo, parece ubicarse el cognitivismo que comprende el aprendizaje como el resultado de procesos internos que no pueden ser observados y en los que las emociones podrían tener por lo menos, un papel secundario. La psicología cognitiva se preocupa por comprender la cognición, es decir, de todos los procesos que entran en escena cuando aprendemos: memoria, percepción y el mismo conocimiento. Como se había mencionado, a diferencia del conductismo, en la corriente cognitivista, las emociones podrían tomar un lugar dada su presencia en el "hexágono cognitivo" formado por la interrelación inteligencia artificial, antropología, psicología, neurociencia, lingüística, y filosofía. Este coctel de influencias haría que asumamos a los estudiantes como seres plurales con necesidades y contextos diferentes, lo que coincide con la postura sobre el lenguaje que presentamos en páginas anteriores. Piaget y Vygotsky, son dos de los representantes más importantes de la psicología cognitiva dados sus aportes desde el constructivismo y el socioconstructivismo, respectivamente.

\subsection{Vigencia del constructivismo - Piaget}

Para comprender los aportes que han hecho corrientes de corte psicológico y pedagógico como el constructivismo y el socioconstructivismo a la educación infantil, en general y a los procesos de lectura y escritura, en particular, es necesario una visita a la antigua Grecia para vislumbrar la genética, en sentido metafórico, del sistema educativo y de éstas corrientes, de ahí que en éste libro nos ocupemos de teorías antiguas que parecen haber pasado de moda, pero que en realidad están camufladas en las prácticas pedagógicas, en los discursos pedagógicos y en las didácticas actuales que viven entre nosotros casi sin darnos cuenta.

Con la aparición del lenguaje oral en la primera infancia (2 a 7 años) las conductas resultan profundamente modificadas. El egocentrismo mantiene su vigencia aunque con menos consistencia, lo que es posible evidenciar en la incapacidad del pequeño para respetar o adaptarse a las reglas de un juego. En cuanto a lo afectivo, aparecen los sentimientos de simpatía o no por las personas, valores como el respeto, la admiración y la cooperación. El adulto entra en este mundo y juega un rol de modelo a seguir (casi como un dios) a este adulto-dios inicialmente no le son 
cuestionadas sus aseveraciones, por tratarse de un ser divino, éste cuestionamiento aparecerá finalizando la etapa con la necesidad de los pequeños por conocer no solo la causa sino la finalidad.

Si el ser humano por naturaleza quiere aprender, en la primera infancia, esta necesidad se encuentra en su mayor auge. Los niños formulan preguntas a las que el adulto responde explicando la causa y no la finalidad. Con la respuesta "equivocada" por parte del adulto, el pequeño continúa indagando para satisfacer sus necesidades de aprendizaje. Es precisamente esta urgencia por comprender la que abre paso a la conocida etapa del "por qué", que se torna en la herramienta perfecta para obligar al adulto (que ya ha perdido tintes de dios) a satisfacer sus necesidades de respuesta ya no solo por la causa sino especialmente por la finalidad. Es al inicio de esta etapa preoperatoria donde se fortalece la función simbólica que aparece al finalizar la sensoriomotora, leemos en Estudios sobre lógica y psicología:

Hacia el año y medio o dos años aparece la "función simbólica", el lenguaje, el juego simbólico (comienzo de la fabulación), la imitación diferida (es decir, la que tiene lugar algún tiempo después del suceso original) y ese tipo de imitación interiorizada que da lugar a las imágenes mentales. Como resultado de la función simbólica se hace posible la "formación de la representación", es decir, la interiorización de las acciones en pensamientos. Se amplía considerablemente el campo en el que la inteligencia desempeña un papel (Piaget, 1993, p. 46).

De esta forma, los hechos ocurridos en la vida del niño cobran importancia y son reproducidos a través del juego, la imaginación y el juego de roles, esta es una de las razones más importantes por las cuales el profesor debe brindar protagonismo a la interacción oral del niño porque es la herramienta con la cual se puede potenciar pensamiento y procesos cognitivos de alto nivel. Esta segunda etapa de desarrollo se presenta el animismo, el artificialismo y el finalismo así como las tres consecuencias esenciales para el desarrollo mental; la del inicio de la socialización, en la cual el niño empieza a usar su lenguaje para comunicar sus acciones o comportamientos, es precisamente es ésta etapa la propicia para que el adulto o docente acompañe su palabras o frases con acciones (especialmente cuando de un segundo idioma se trata) con el fin de dar doble oportunidad al pequeño para que comprenda y asimile los nuevos conceptos, si cada comando está acompañado de la acción o movimiento corporal, el pequeño enriquecerá más fácilmente su lenguaje y por ende su socialización y pensamiento se dará más rápidamente. 
La segunda es el pensamiento que es la evidencia de que la palabra y los signos están interiorizados y finalmente la intuición que es la forma superior de equilibrio que alcanza el pensamiento propio de la primera infancia y que concluye con la "operación", es decir, solo se da la operación cuando el pensamiento ha pasado por lo sensorio - motriz y lo intuitivo y a su vez, la intuición solo se convierte en operación cuando el pensamiento infantil logra dominar al menos en cierto grado conjuntos componibles y reversibles lo que sin duda alguna requiere de acciones interiorizadas, es decir de pensamiento, al reconocer la existencia de los demás y por ende, construir relaciones afectivas que logren discernir el papel del adulto, hasta lograr abolir el respeto unilateral y lograr el mutuo.

El niño de 7 u 8 años (es decir que inicia la segunda infancia) empieza a liberarse de su egocentrismo social e intelectual, en consecuencia después de los 7 años el niño piensa antes de actuar y comienza a conquistar la difícil conducta de la reflexión, que no es otra cosa que una conducta social de discusión, pero interiorizada, porque ya construye explicaciones no solo alrededor de lo que hace o ve él mismo sino los demás.

Por otro lado, Piaget (1983) defiende el juego como actividad central de la educación infantil porque las capacidades sensorio motrices, simbólicas o de razonamiento, como aspectos esenciales del desarrollo del individuo, son las que condicionan el origen y la evolución del juego. La complejidad e importancia del juego lo llevó a hacer la clasificación en tres estructuras básicas del juego con las fases evolutivas del pensamiento humano: el juego es simple ejercicio (parecido al anima); el juego simbólico (abstracto, ficticio); y el juego reglado (colectivo, resultado de un acuerdo de grupo).

A pesar de los significativos aportes que Piaget hizo a la educación y a la psicología, se limitó a comprender la cognición sin dedicar la suficiente atención a lo emocional, a las relaciones y construcciones con los demás campo del que se ocupó Vygotsky.

Aunque ciertos aportes piagetianos han sido puestos en tela de juicio (como las edades) en la educación actual dada la sociedad contingente y paradójica en la que vivimos, también es importante resaltar aquellos que cobran vigencia como las etapas de desarrollo (sensoriomotora de 0 a 2 años, preoperacional de 2 a 7 años, operaciones concretas de 7 a 12 años y operaciones formales o abstractas de 13 hasta la adultez). Del ambiente como elemento que determina la velocidad en que los niños se desarrollan han dado cuenta numerosos autores, entre otros, Vygotsky con el Socioconstructivismo, Albert Bandura con el aprendizaje social, Abraham 
Maslow con el humanismo, Jerome Bruner con el aprendizaje por descubrimiento, Ausubel con el aprendizaje significativo por nombrar algunos. Cada uno de estos postulados permiten comprender el aprendizaje infantil desde diferentes frentes, pero coinciden en una aseveración: el valor cognitivo, afectivo y social de los saberes previos de los pequeños, los mismos que se convierten en cimientos sobre los cuales se construyen nuevos cocimientos. En síntesis, si el ambiente (familia, sociedad, escuela) determina el nivel en que los niños avanzan (lo cognitivo, lingüístico, físico, inclusive), no es posible hablar de edades exactas e independientes para procesos plurales y dependientes.

$\mathrm{Al}$ igual que las etapas de desarrollo, la teoría de la equilibración desencadenaría en la revolución cognitiva una ráfaga de teorías que lejos de ignorar la cognición o los procesos mentales como lo hizo el genetismo y posteriormente el conductismo, le atribuirían el primerísimo lugar. Leemos en El nacimiento de la inteligencia en el niño:

Tres circunstancias nos mueven a considerar de éste modo a la asimilación como el dato fundamental del desarrollo psíquico. La primera es que la asimilación constituye un proceso que la vida orgánica y la mental poseen en común y en consecuencia, es una noción común a la fisiología y a la psicología [...] en segundo lugar, la asimilación explica el hecho primitivo generalmente admitido como el más elemental de la vida psíquica: la repetición (en tercer lugar, [...] la coordinación entre lo nuevo y lo viejo, que anuncia el proceso del juicio (Piaget, 1977, p. 48-49).

Es así como la teoría de la equilibración nos hace menos ingenuos frente a la importancia de los conocimientos con los que los estudiantes en general y los niños en particular, cuentan en el acto educativo, pues son precisamente esos conocimientos previos (aspecto en el que Piaget y Ausubel coinciden) los que les permiten comprender o "asimilar" los conocimientos nuevos, de suerte que todo conocimiento nuevo que el maestro comparta con los niños pueda tener múltiples conexiones con sus preconceptos, lo que facilitaría su comprensión, análisis e internalización, es decir, que pasarían a formar parte de las estructuras cognitivas de los niños, lo que en Piaget conocemos como la acomodación y en Vygotsky la zona de desarrollo potencial.

\subsection{Vigencia del socioconstructivismo - Vygotsky}

Para comprender la importancia de prácticas pedagógicas apropiadas en los procesos de lectura y escritura en la primera infancia y más aún en la relación 
entre pensamiento y lenguaje, es necesario recurrir a estudiosos que han hecho aportes trascendentales al respecto. Las actuales comprensiones entre pensamiento y lenguaje, se las debemos en gran medida a Vygotsky, quien sostiene que las raíces del pensamiento y del lenguaje son diferentes, en lo filogenético y ontogenético.

En lo filogenético encuentra que el lenguaje y el pensamiento no solo tienen diferentes raíces y se desarrollan de manera independiente, sino que, además, no sostienen relación constante ni definida aunque si hay momentos en los que se encuentran y se unen para luego volver a divergir. De acuerdo con Vygotsky, el humano y el antropoide presentan la siguiente diferencia: aunque ambos lleguen al balbuceo, los antropoides no alcanzan a desarrollar la relación entre pensamiento y lenguaje dado que su comportamiento no es producto del pensamiento sino del instinto (del cerebro reptil de acuerdo con MacLean). En consecuencia, el antropoide no llega a la etapa pre intelectual en cuanto al habla ni pre lingüística en el pensamiento, todo esto obedece a que en el ser humano primero es el pensamiento, la acción, el uso de herramientas y luego se da el lenguaje, en otras palabras, el pensamiento está determinado por el lenguaje que requiere del dominio de los medios sociales de pensamiento en su proceso histórico y cultural.

En lo ontogénico el desarrollo del lenguaje sigue cuatro fases: la primitiva que comprende el lenguaje pre intelectual y pensamiento pre verbal. la psicológica simple, en donde el niño utiliza su cuerpo para experimentar y usar herramientas, la egocéntrica donde usa signos externos para solucionar problemas internos y construir relaciones, y la de crecimiento interno donde opera con relaciones y signos interiorizados. Los conceptos por su parte, son procesos mediados que se forman con el uso de la palabra, la conversión en símbolos y la trasferencia a otros objetos. Las fases en que se forman los conceptos son: el sincretismo que son cúmulos inorganizados, es decir agrupamiento que hace el pequeño apostando al ensayo - error, el pensamiento en complejos, en el cual se asocia por vínculos o relación entre elementos, rasgos comunes, seudoconceptos y finalmente los conceptos que contienen operaciones de orden superior como la abstracción, el análisis y la síntesis. Estas fases siguen un proceso de desarrollo en la infancia que va desde los conocimientos cotidianos hasta los conceptos científicos o mediatizados.

En Pensamiento y lenguaje, Vygotsky sostiene que éstos se forman como una unidad: el pensamiento nace a través de las palabras y se amalgama en el significado, pero depende del proceso evolutivo. Señala también la diferencia entre lenguaje externo, interno y egocéntrico, siendo el primero fonético, es decir, reproducir el pensamiento por medio de palabras, el segundo es significativo y semántico, va de lo general a lo particular, es pensamiento interno. Finalmente, el lenguaje egocéntrico que es precisamente la transición entre lenguaje 
propio (aquel que uso para comunicarme conmigo mismo) y el que utilizo para comunicarme con los demás.

La etapa que se encuentra entre el lenguaje egocéntrico y el lenguaje social primario infantil, el niño se percibe como predicado, es decir, el sujeto no es importante, lo que se puede evidenciar fácilmente al observar el juego de dos niños en la etapa de egocentrismo, cada uno de ellos se siente merecedor de todo, por eso no comparten sus juguetes y pretenden que el otro lo haga, esto es el lenguaje egocéntrico. Si intentáramos explicar el mismo fenómeno con lenguaje exteriorizado, podríamos explicar la tacitez del sujeto cuando en la misma etapa de egocentrismo solo usa respuestas cortas, evadiendo darle importancia al sujeto.

Por fortuna, esta etapa de egocentrismo se supera cuando inicia el lenguaje exteriorizado o lenguaje social primario infantil, he aquí la importancia de permitir a los niños y niñas desarrollar su oralidad e interactuar en clase con sus compañeros toda vez que el contexto cobra importancia porque el otro entra a formar parte de las conversaciones y con ellos sus ideas. El desarrollo del habla y pensamiento, de acuerdo con Vygotsky, se encuentran separados por lo menos hasta los dos años, a partir de esta edad, se unen para iniciar una nueva forma, el pensamiento de vuelve verbal y el lenguaje se convierte en racional. Leemos en Pensamiento y lenguaje:

Por ahora solo haremos saber que "el descubrimiento más importante del niño" solo se hace posible cuando se ha alcanzado determinado nivel, relativamente alto, el en desarrollo del pensamiento y el lenguaje. En otras palabras, el lenguaje no puede ser "descubierto" sin el pensamiento. Brevemente, podemos concluir que:

Brevemente podemos concluir que: 1. En su desarrollo ontogenético, el pensamiento y el lenguaje provienen de distintas raíces genéticas. 2. En el desarrollo del habla del niño podemos establecer con certeza una etapa preintelectual, y en su desarrollo intelectual una etapa prelingüística. 3. Hasta cierto punto en el tiempo, los dos siguen líneas separadas, independientes una de otra. 4. En un momento determinados estas líneas, se encuentran y entonces el pensamiento se torna verbal y el lenguaje, racional (Vygotsky, 1987 , p. 72).

Como es evidente, la dicotomía o separación lenguaje-pensamiento no es natural, es heredada y nos hizo perder la pista sobre la importancia de comprenderlos como una unidad que con los matices que ofrecen las culturas y el entorno familiar y 
social, se resignifica y reconstruye a sí misma en la medida en que interactúa con el medio. Este descubrimiento de la separación inicial y unión posterior del lenguaje y el pensamiento en el desarrollo natural infantil, debe cambiar la posición de padres y especialmente de maestros que lejos de permitir a los pequeños interactuar con otros y con el entorno, los encierran en las aulas de clase y les prohíben conversar y jugar, disminuyendo drásticamente las posibilidades de "ingresar" a sus estructuras cognitivas conocimientos que le permitirán comprender el mundo para luego exteriorizarlo a través de las palabras.

Podríamos afirmar que es a partir de esta etapa social que el contexto marca las palabras y estas a su vez son marcadas por el contexto, es decir, no es posible mantener una comunicación donde los conceptos por lo menos se acerquen a lo que cada uno de los interlocutores asume de ellos sin estar de alguna manera vigilados por el contexto. El contexto es parte inherente a la comunicación. Pensar la comunicación al margen del contexto es un a anteojera que sacrifica el significado pragmático de las palabras y las expresiones porque estas cobran vida y sentido de acuerdo al contexto, no al margen de él. El lenguaje se trasforma, de acuerdo con Vygotsky, de afuera a hacia adentro. Continuamos con Pensamiento y lenguaje:

Tendríamos entonces que contestar a la siguiente pregunta: por qué el lenguaje se convierte en interiorizado. Y respondernos que es porque cambia su función. Su desarrollo debería comprender todavía tres etapas, no las que considera Watson, sino éstas: lenguaje externo, lenguaje egocéntrico, lenguaje interiorizado. (...). Nuestras investigaciones demuestran que el desarrollo del lenguaje sigue el mismo curso y obedece a las mismas leyes que todas las otras operaciones mentales, involucrando el uso de signos, tales como la numeración o las ayudas mnemónicas (Vygotsky, 1987, p. 74).

A este lenguaje social primario lo sucede el lenguaje interiorizado, donde de nuevo la tacitez y la abreviación, tienen lugar, pero esta vez, no están vigilados por el egocentrismo sino como lo había mencionado por el contexto, por eso, para que el lenguaje abreviado tenga frutos en la comunicación en necesario que quienes comparten el dialogo tengan en común ciertos conocimientos sobre el tema, y por tratarse de lenguaje interiorizado, hay que tener especial cuidado con las palabras, pues la pluralidad de su significado puede igualmente tergiversar la idea original que se pretende trasmitir.

En síntesis, hay un sinnúmero de fenómenos que atraviesan el lenguaje y la comunicación, por eso, vivir plenamente estas etapas orales es la clave para llegar 
al lenguaje escrito, siendo éste la forma más elaborada del lenguaje, pues en él la semántica de las palabras no solo se apoyan en los gestos, los conocimientos comunes, los tonos o contextos, porque quedan a merced de los sentidos y acepciones que otorguen quienes las puedan leer.

Aunque Vygotsky no vivió por mucho tiempo, logró trascender, como se ha podido evidenciar, las fronteras de la comprensión del lenguaje y las construcciones sociales. Las zonas de desarrollo (real, próxima y potencial), cobran vigencia en un mundo que necesita del trabajo en equipo para avanzar desde diferentes frentes, entre otros, el del respeto por las diferencias, el educativo e integral y el de la educación en ciudadanía como lo podrán encontrar en el siguiente aparte de este libro. Lejos de promover la individualidad, el socioconstructivismo o constructivismo social promueve el trabajo en equipo y nos hace menos ingenuos frente a nuestras estructuras cognitivas toda vez que la construcción colectiva hace que el otro se convierta en una especie de "sparring" que pone en tela de juicio, o si se prefiere, pone a prueba nuestras comprensiones sobre un tema determinado, logrando que la interacción se convierta en una construcción colectiva en doble dirección, "soy el sparring del otro y el otro es mi sparring". Se aclara que de acuerdo con Vygotsky, este proceso solo puede darse en la zona de desarrollo próximo si una de las personas que interactúa cuenta con mayor formación en el tema o área específica que se está trabajando.

Pensar en Vygotsky en general y en el socioconstructivismo en particular, remite de forma obligatoria a la zona de desarrollo próximo, gracias a la cual, de acuerdo con Vygotsky "aprendemos en compañía del otro", leemos en su más gran obra Pensamiento y lenguaje:

El crecimiento progresivo de los niveles más altos del pensamiento científico y el rápido incremento de del porcentaje de conceptos cotidianos confirman que la acumulación de conocimientos conlleva al aumento de nivel de los tipos de pensamiento científico, lo que a su vez incide en el desarrollo del pensamiento espontáneo, demostrando el papel rector de la enseñanza en el desarrollo escolar (Vygotsky, 1987, p. 267).

Si la clave está en la interacción como menciona Vygotsky, la familia y la sociedad debe permitir a los pequeños interactuar con personas que los lleve de la zona de desarrollo real a la zona de desarrollo potencial a través de la zona de desarrollo próximo y la aventura que ésta podría representar cuando se conoce su poder para mejorar la sociedad y la educación, especialmente la educación en la primera 
infancia. Tener en cuenta lo anteriormente mencionado daría la oportunidad de los niños y niñas a que se valoren sus avances y no sus dificultades:

Durante un tiempo nuestras escuelas favorecieron el sistema «complejo» de la instrucción, que se pensaba estaba adaptado a los modos de pensamiento del niño. Al ofrecerle problemas que podría manejar sin ayuda, este método dejó de utilizar la zona de desarrollo próximo y de conducir al niño hacia lo que todavía no podía hacer. La instrucción estaba más orientada hacia la debilidad del niño que hacia su fortalecimiento, y de este modo los instaba a continuar en la etapa preescolar de desarrollo (Vygotsky, 1987 p. 267).

El poder de la zona de desarrollo próximo en la que se da la interacción, la internalización, es decir, el paso de lo interpersonal a lo intrapersonal (funciones mentales superiores), se hace evidente. Favorecer la interacción de los niños, en lugar de reprimirla, no solo haría la diferencia, sino que, además, es un compromiso de la educación con la infancia en beneficio de la educación integral.

\subsection{Pedagogía y educación integral. Una obligación, un derecho en la primera infancia}

Este aparte del libro propone comprender las tendencias actuales de las prácticas pedagógicas en la primera infancia y responder a las siguientes preguntas ¿Cuáles son las políticas oficiales que protegen la educación en el preescolar? ¿Todas las prácticas actuales atienden a las necesidades reales de los pequeños? ¿Cuáles son los discursos y las prácticas pedagógicas más importantes que permite a los niños y niñas avanzar en su proceso integral? ¿Cuál es el tipo de maestro que reclaman las prácticas y los niños actuales?

De acuerdo con el Ministerio de Educación Nacional, la educación integral, es la atención armónica que se brinda, en este caso a los pequeños desde diferentes frentes: salud, nutrición, protección y educación inicial en diversos contextos (familiar, comunitario, institucional), aumentando las posibilidades de sobrevivir, crecer, desarrollarse y aprender.

Muchos han sido los años de ingentes esfuerzos por brindar protagonismo a la educación infantil, el Gobierno Nacional a través del Ministerio de Educación Nacional (en adelante MEN), por ejemplo, ha trazado aspectos puntuales como la inserción del preescolar en el sistema educativo (decreto 088 de 1976), los derechos 
fundamentales de los niños colombianos (Constitución Política de Colombia 1991), la importancia del preescolar como espacio que amplía las relaciones y potencia el desarrollo infantil, por lo tanto, su obligatoriedad (Ley 115 de 1994), o la inclusión de los niños con necesidades educativas especiales (decreto 2082 de 1997, ley 1145 de 2007, decreto 366 de 2009), hacen parte de las tendencias propias de las políticas oficiales. Por otro lado, el MEN en los artículos 15, 16 y 17 de la Ley general de educación o Ley 115 (1994), definió la educación preescolar como “[...] la ofrecida al niño para su desarrollo integral en los aspectos biológico, cognoscitivo, sicomotriz, socio-afectivo y espiritual, a través de experiencias de socialización pedagógicas y recreativas" (p. 27). De esta forma, el nivel preescolar, de acuerdo con el decreto 2247 (1997), comprende los grados pre-jardín, jardín y transición (3, 4 y 5 años respectivamente); tres grados de los cuales solo el último es obligatorio.

La creciente ola de tendencias de prácticas pedagógicas complejiza la labor de quienes nos ocupamos de la educación en el preescolar, pero la enriquece a la vez al proponer un amplio abanico de posibilidades que el maestro debe filtrar y adoptar de acuerdo a las necesidades buscando siempre la más apropiada o útil para sus pequeños pero sin posibilidades, por fortuna, de elegir una fórmula de estirpe pansofica que funcione para todos (Comenio, 1988).

Sin el ánimo de caer en el universalismo, cuando se habla de tendencias actuales en la práctica pedagógica de la educación preescolar, suele pensarse en dos direcciones: las desafortunadas y las afortunadas. En el primer caso, lejos de favorecer la educación integral de los pequeños, persiste en una mayéutica vergonzante (Skinner, 1974) que a través del Estimulo - Respuesta, parece estar legitimando lo que hoy se conoce como educación bancaria y repetitiva (Freire, 1970). En este tipo de educación a mayor repetición de un estímulo positivo, más se fortalece ese comportamiento, por lo tanto, se alarga la vida de la memoria. Estas tendencias están presentes en las prácticas pedagógicas de aquellos maestros de preescolar que continúan implementando estratagemas pedagógicas de antaño que ignoran, en la mayoría de los casos, el potencial de los niños y niñas al llegar a la escuela perpetuando el "cómo me educaron educo", ignorando la contingencia de la sociedad actual, la misma que cambia a la velocidad del vértigo, que nos desborda y nos deja sin tiempo para pensar. En síntesis, los maestros que practican ésta primera forma de tendencia pedagógica, asumen los niños como "mentes vacías" y los educa con estrategias pedagógicas del pasado, perpetuando un desfase y un engaño que los niños y la sociedad pagan con intereses de usura porque los prepara para una sociedad que ya no existe o por lo menos no es la que viven los niños actuales. 
Estas tendencias desafortunadas, sin embargo, no son las que nos interesa profundizar, por el contrario, nos centraremos en el segundo tipo de tendencias pedagógicas que lejos de promulgar una única forma de aprendizaje y clasificar a los estudiantes en función de un tipo de inteligencia (Gardner, 1999). Reconoce los cambios sociales, comprende los niños como seres integrales con diferentes necesidades y permiten identificar sus fortalezas en lugar de las carencias.

Intentaremos comprender las tendencias actuales en la práctica pedagógica de la educación preescolar que nos interesan desde dos frentes esenciales: el primero, desde las políticas o discursos oficiales de orden internacional, nacional, regional e incluso local como el PEI, y el segundo, desde los aportes teóricos que grandes pensadores a través de la historia han hecho en beneficio de la educación, en general y de la educación en la edad preescolar, en particular. Ambos frentes convergen en la importancia de brindar en el preescolar una educación integral en la que no solo se reconozcan y valoren los pequeños, sino que, además, de acuerdo con el MEN (1998) se:

potencien capacidades, aptitudes y actitudes [...], se anime el espíritu científico y creativo de todos los que intervienen en el proceso educativo, alrededor de las actuales tendencias pedagógicas, psicológicas, filosóficas y socio-culturales, que favorecen el desarrollo de la educación preescolar ( $\mathrm{p}$. $12)$.

Si la edad preescolar comprende niños entre 3 y 5 años de edad, las tendencias actuales de las prácticas pedagógicas en educación preescolar deben estar encaminadas a comprender los procesos emocionales, sociales, cognitivos y biológicos propios de esta edad. Si entender la influencia del entorno social en el aprendizaje, en el estado emocional, en las cogniciones inclusive determina la educación integral, las prácticas pedagógicas deben estar encaminadas en esa dirección. Sobre la "educación situada" Díaz Barriga menciona en su texto Enseñanza situada: vínculo entre la escuela y la vida, que los contenidos teóricos deberían ser insumos y oportunidades para aprender a pensar y a razonar, que para mejorar el aprendizaje hay que mejorar la enseñanza, pero hace especial énfasis en que los contenidos deben enseñarse in situ, es decir, utilizar problemas de la vida diaria, lo que sin lugar a dudar, conecta la teoría con la práctica. La propuesta de Díaz Barriga de incluir en las prácticas pedagógicas el AMC (Aprendizaje Mediante Casos) y el ABP (Aprendizaje Basado en Problemas), no solo permiten al docente promover y desarrollar competencias integrales, sino que, además, aprueba a los niños utilizar sus conocimientos previos (Ausubel) como materia prima en el acto educativo. 
Resulta determinante repensar las tendencias actuales de las prácticas pedagógicas en el preescolar mediante elementos que las componen y que consideramos de gran importancia porque favorecen la calidad educativa e integral de los niños y niñas y hacen que su paso por el preescolar se convierta en una gran aventura, algunos son: inclusión, evaluación, lectura y escritura desde la significación, oralidad, proyectos pedagógicos, inteligencias múltiples, el juego, la imaginación, la narrativa, las TIC.

Estrategias como la inclusión no solo abren las posibilidades a los niños con necesidades educativas especiales de compartir procesos sociales y educativos en un mismo espacio físico o emocional, sino que, además, desarrolla en los niños llamados "regulares" o "normales" la capacidad de conmoverse, reconocer y valorar las diferencias fortaleciendo su formación integral. La evaluación de este tipo de población debe obedecer a una adaptación curricular, al igual que para los niños "normales o regulares", el proceso evaluativo debe ser un proceso continuo e integral en el que de manera conjunta docentes, padres y comunidad identifiquen cualitativamente los aspectos que facilitan o dificultan los procesos de los niños y en consecuencia generen los cambios necesarios (MEN, 1997). De esta forma, las tendencias en el manejo de la evaluación (resolución 2343 de 1997), desde el punto de vista pedagógico, requiere que el docente formule sus propios indicadores de logro de manera que atiendan a los seguimientos del MEN, a los definidos en el proyecto educativo institucional (PEI) y la realidad cultural, social y personal de los niños.

De la misma forma, aunque el lenguaje siempre ha permeado los procesos educativos, hoy más que nunca se defiende su protagonismo en la educación infantil, por lo que las prácticas pedagógicas actuales reconocen su conexión con el pensamiento. Leemos en los lineamientos curriculares de preescolar:

En el periodo de tres a cinco años de edad [...] el lenguaje se convierte en una herramienta esencial en la construcción de las representaciones [...]. La utilización constructiva del lenguaje se convierte en instrumento de formación de representaciones y relaciones y, por tanto, de pensamiento (MEN, 1998, p. 36).

Es por eso que la compresión de los procesos de desarrollo infantil desde lo sicogenético y lo psicogenético hacen parte de las tendencias pedagógicas actuales toda vez que permiten comprender las múltiples formas de cognición infantil. Si los niños y niñas están perfectamente dotados con estructuras mentales que les permite 
producir y procesar conceptos científicos de acuerdo con Vygotsky (1987) ¿por qué continuamos enseñando conceptos aislados y libres de contexto?

Es menester adelantar un giro copernicano que permita adoptar esta tendencia pedagógica y recupere la centralidad del lenguaje entre otros, en el plano educativo, para ello el MEN y autores nacionales como Gloria Rincón o de talla internacional como Emilia Ferreiro y Liliana Tolchinski han hecho aportes significativos que permiten comprender que antes de ingresar a la escolaridad los niños han construido hipótesis sobre la lengua y la significación; el dibujo, por ejemplo, resulta ser una forma de simbolización bastante compleja al igual que el juego; y las formas no convencionales de escritura que usa el niño son significativas y obedecen a procesos de evolución de la lengua, es por eso que el lenguaje ha de ser la herramienta central en las prácticas pedagógicas y a través de él que es posible avanzar posteriormente en procesos tan complejos como la lectura y la escritura pero siempre con la siguiente claridad:

[...] el manejo del código alfabético convencional es un punto de llegada y no un punto de partida en el desarrollo natural de la significación en el niño. Por tanto, los enfoques que toman como punto de partida el fonema, la sílaba y la palabra, poniendo el énfasis en la relación sonido/grafía, no son pertinentes como iniciación a la escritura. En este sentido, resulta necesario generar espacios de significación en los que la escritura cobre sentido social, y el problema de la fonetización y el acceso al código alfabético serán una necesidad que aparece de manera natural (MEN, 1998, p. 54).

Con respecto al lenguaje escrito propio de niños y niña en edad preescolar, como garabateo, trazos, líneas, combinaciones o dibujos, es necesario dotarlos de la importancia que merecen, para su comprensión las etapas de desarrollo piagetianas y los niveles del sistema de escritura infantil propuestos por Emilia Ferreiro, los documentos del MEN: el documento 10 (2009), y el documento 21 titulado "El arte en la educación inicial" (2014), inclusive, son referentes obligados que pueden converger en los proyectos pedagógicos toda vez que abarcan el sentido de la educación inicial, las actividades rectoras de la primera infancia como el juego, el arte, la literatura y la exploración del medio y, por último, el seguimiento al desarrollo integral de los niños y las niñas en el entorno educativo.

Los proyectos pedagógicos, son una de las herramientas más presentes en las tendencias actuales de la pedagogía en el ámbito de la educación infantil, resultan 
ser una de las mejores opciones que permiten la transversalidad entre las áreas del conocimiento y responder a las necesidades de los niños y niñas de forma globalizada e interdisciplinaria. Formulado, ejecutado y evaluado con la ayuda de padres, niños, comunidad y escuela, los proyectos pedagógicos de acuerdo con el MEN (1998) permiten "desarrollar procesos de investigación que se emprenden para encontrar respuestas, y generar más inquietudes de conocimiento, en la medida que los niños van profundizando en lo que quieren conocer y hacer" (p.47). Esto hace evidente la continua retroalimentación entre teoría y práctica, lo que garantiza que estas dos dimensiones tengan sentido. El juego, en la primera infancia, lejos de ser inútil o una "pérdida de tiempo" de acuerdo con Piaget (1983) es la actividad que más posibilita al niño y a la niña aprender y pasar del egocentrismo a compartir con los demás. Por su lado Vygotsky, dice que el juego nace de la necesidad natural de tomar contacto con otros (ZDP), el juego abre la oportunidad de recrear escenas que van más allá de los instintos y pulsaciones internas individuales no pensadas (funciones mentales inferiores). Para Piaget (1959), el juego representa el proceso de asimilación funcional o reproductiva de sus realidades, de acuerdo a la etapa de desarrollo que se encuentre cruzando. En esas condiciones, la etapa determina la inteligencia porque las capacidades sensorio motrices, simbólicas o de razonamiento, como aspectos esenciales del desarrollo del individuo, son las que condicionan el origen y la evolución del juego.

Los avances en el plano neurocientíficos dan cuenta de la importancia del juego en la primera infancia, si además de uno tenemos tres cerebros de acuerdo con MacLean (1973), si uno de ellos está dedicado a filtrar las emociones, el juego se torna en una actividad imprescindible en la educación de la primera infancia por sus bondades en la conexión emoción-razón, es decir, entre la alegría y el conocimiento. En síntesis, el juego se convierte en un espacio gratuito para ensayos de hechos reales en ambientes seguros dice Brunner (1988), en escenario terapéutico según Freud, (1974), de preparación mental y social inconsciente para Dewey (1934), en aprendizaje sensorial y trabajo lúdico sostiene Montessori (1936), de desarrollo intelectual para Piaget y desarrollo social según Vygotsky Inherente al juego, la imaginación infantil representa la herramienta intelectual más potente y dinámica con la que los niños llegan a la escuela. El canadiense Kieran Egan (1999), sostiene que no hay niño que se resista al escuchar el "Érase una vez". La habilidad innata de los niños y niñas para imaginar y fantasear hace que la narrativa infantil tome protagonismo en el aula de clase. Los cuentos son una poderosa herramienta de aprendizaje cuya materia prima es la imaginación, por lo que toca fibras afectivas infantiles e imprimen emoción individual y colectiva. Si la fantasía y la imaginación son los elementos que es lo que más abundan en la mente infantil ¿por qué hacer de ellos invitados fantasma? 
Todo lo esbozado hasta este momento se encuentra inmerso en la teoría de las inteligencias múltiples de Howard Gardner, con quien hemos tenido la oportunidad de trabajar directamente en la Universidad de Harvard desde hace algún tiempo. Gracias a esta teoría que tuvo su cuna en los años 80 y que reformula en 1999 en su libro Intelligence reframed. Esta teoría pone en tela de juicio las prácticas pedagógicas tradicionales en las que el protagonismo se lo llevan las capacidades lingüísticas y lógico-matemáticas en detrimento del resto de aptitudes que un ser humano, en este caso, lo niños, tienen y necesitan desarrollar. Actualizada la idea de inteligencia y planteada la diversidad humana, los estereotipos de inteligencia que sostienen la eficacia del Método con mayúscula, como el propuesto por Comenio (1988) en la Didáctica Magna, deben desaparecer de las prácticas pedagógicas actuales. La integración de las Tic en las actividades diarias de los pequeños no solo permite actualizar prácticas pedagógicas de antaño y abrir un mundo de posibilidades para los pequeños sino que, además, demostrarían la vigencia de la teoría de las inteligencias múltiples toda vez que muchos maestros las satanizan porque no están en condiciones de usarlas, por lo que deberíamos preguntarnos ¿acaso no son inteligentes?

Las tendencias actuales en las prácticas pedagógicas de la educación preescolar exigen docentes que lejos de centrase en la repetición y transmisión de contenidos libres de contexto, comprendan los cambios sociales, propongan actividades que den rienda suelta a la genialidad infantil e incrementen los niveles de interés por el aprendizaje mediante el "tránsito" seguro de la vida familiar a la comunitaria, aumentando los niveles de equilibrio y felicidad infantil y disminuyendo los de tristeza, antipatía académica y deserción escolar. Maestros que den rienda suelta a la imaginación, al juego, a la creación, que sueñen con los pequeños, que exploren, que los ayuden a expresarse de formas diferentes.

\section{TENDENCIAS ACTUALES}

Esta sección tiene como objetivo fundamental compartir desde la teoría, algunas tendencias pedagógicas relacionadas con los procesos de lectura y escritura en la primera infancia de suerte que quienes se interesan por la educación infantil puedan reflexionar sobre su propio quehacer pedagógico y adoptar posturas teóricas que puedan traducir en apuestas didácticas y/o metodológicas acordes a las necesidades específicas del contexto y de los pequeños.

El déficit motivacional de las éticas cognoscitivas del que se quejan los intelectuales en la actualidad, serían fruto de estrategias que continúan apostando al famosos 
adagio "el fin justifica los medios". No se pretende entrar en el juego de señalar una estrategia pedagógica como la adecuada y la otra como el verdugo, pero sí enfatizar en la importancia de buscar el "justo medio" (Jullien). Hacer un diagnóstico previo de los estudiantes e implementar postulados teóricos y prácticas pedagógicas en consecuencia, resulta determinante. El compromiso del maestro de la primera infancia es educar con el ejemplo y desarrollar oralidad, es allí donde la pragmática lingüística cobra importancia y señala una forma de favorecer y desarrollar el lenguaje, que si bien no es el único, sí es el más adecuado porque permite, entre otras cosas, un aprendizaje significativo (Ausubel) en el que los saberes previos de los pequeños tomar importancia, se tienen en cuenta las formas de aprender (Gardner) y se hace la conexión de los tres cerebros (MacLean) de acuerdo con los cuales, la emoción no es títere de la razón.

En síntesis, las prácticas pedagógicas actuales en la primera infancia necesitan que los niños, lejos de estar hipnotizados, tristes, preocupados, descontextualizados e inmóviles en sus escritorios, se conviertan en los actores principales de su propio proceso de aprendizaje, que jueguen, que conversen, que interactúen con situaciones auténticas, con sus compañeros y docentes, que fantaseen y den rienda suelta a su imaginación. Es necesario que los docentes de la primera infancia, permitan a los niños equivocarse y pasar por las etapas normales desde todos los frentes: biológico, psicológico, cognitivo y afectivo, solo cuando el niño hace su propio proceso, se equivoca y se levanta, logra comprender cómo funciona un sistema determinado (social, académico o de lectura y escritura específicamente).

Es un temor sin fundamentos cognitivos y emocionales el que experimentan los maestros a que los niños se "equivoquen", a que escriban las palabras con "errores" comunes y naturales cuando de notación alfabética se trata, entre otros: representar palabras o frases con garabatos, escribir palabras en donde faltan o sobran letras, combinar letras con números, combinar garabatos con números, inventar formas grafémicas, asumir sonidos de letras como si fueran sílabas, confundir la p con la q o la d con la b, éstas últimas, por ejemplo, no siempre son productos de enfermedades como la digrafía, la dislalia o la dislexia sino, casi siempre, problemas de práctica y discurso pedagógico. Lo grave del asunto es que son los pequeños quienes pagan con intereses de usura las prácticas pedagógicas anacrónicas y planas, es decir, aniquiladoras de la primera infancia.

Con respecto a los padres de familia, es necesario que la institución y el docente en particular, inicie un proceso se sensibilización que les permita comprender a los padres, que el cuaderno no mide de ninguna manera los aprendizajes de los niños 
en la primera infancia, realmente funciona al revés, a mayor hojas del cuaderno utilizadas, menos pensamiento y lenguaje movilizado. Las largas y repetitivas planas, mandan al lenguaje y al pensamiento de vacaciones porque para desarrollarlas solo es necesaria la motricidad fina. De lo que se trata, es de permitirles desarrollar su oralidad, garabatear, jugar e interactuar, en síntesis, ser niños. Palabras completas y frases completas en contexto permiten a los niños ver esas "manchas de tinta" (como perciben inicialmente las grafías de las palabras) como formas de representar aquello que conocen.

Claramente viejos paradigmas en los que el deletreo y la fonetización cobran protagonismo impiden cuando no sataniza la equivocación en los niños, romperlos y salir de la zona de confort no solo es tarea de los docentes, sino, además, exigen un proceso de sensibilización en los padres de familia porque lo más difícil de trabajar con los niños, no son los niños en sí, sino, sus padres. En esas condiciones, se hace necesario una nueva mirada con respecto a la forma de orientar procesos culturales (porque no son naturales) como el sistema de lectura y escritura no solo desde los docentes en sus prácticas pedagógicas, sino en los padres de familia

Podríamos decir que en el proceso natural de comprensión del sistema de significación, cometer errores además de natural resulta necesario. Permítanme una comparación que espero ayude a comprender lo expuesto en estas últimas líneas: en el sector salud, las vacunas son aplicadas a los pequeños desde su nacimiento porque tiene una función fundamental que lejos de evitarles contraer un virus ellas mismas lo contienen. Las vacunas son un preparado de virus y bacterias muertas o vivas atenuadas, que se utilizan para la prevención de enfermedades infecciosas mediante la inducción de inmunidad activa, lo que buscan es crear anticuerpos y reforzar el sistema inmune de los niños para el resto de su vida, en otras palabras, la vacuna enferma el cuerpo del pequeño para que este reconozca el virus y produzca anticuerpos que le permitirán combatir la enfermedad en la eventualidad que llegare a presentarse en futuro.

Mientras que en la salud las vacunas que inducen al cuerpo a desarrollar formas de defenderse, son puestas desde el exterior, no sucedería lo mismo en el caso de la educación, toda vez que los niños crearían sus propias vacunas, es decir, sus propios "virus y bacterias naturales" (los errores que cometen de manera natural al inventar o combinar garabatos...) y el docente, dentro de su ignorancia (Sócrates) las estaría combatiendo a toda costa por considerarlas invasivas y mortales para su desarrollo. No es otro el error capital de las prácticas pedagógicas.

Los docentes, posiblemente por las presiones del sistema para mostrar resultados, ignoran las bondades de esos virus y bacterias que los niños desarrollan de manera 
natural. Los errores cuando inician la escritura, son un claro y celestial ejemplo del desarrollo integral en general, y cognitivo en particular. Que un niño en lugar de escribir perro, omita la e y escriba prro, resulta un error imperdonable que merece una mala nota, una queja al padre de familia y hasta signos de una enfermedad como la dislexia. Este pequeño "error" si es que así lo podemos llamar, lejos de ser un problema como lo acabamos de esbozar, no es más que la prueba que el niño está atravesando un proceso natural de aprehensión del sistema de escritura en el que sus conocimientos previos sobre un perro, están siendo puestos en escena. Para el pequeño de este ejemplo, la letra e no es necesaria toda vez que el nombre de la letra la p suena como si tuviera la e, o eso fue lo que su profesora le enseñó. He aquí uno de los graves inconvenientes de enseñar letras separadas y sin sentido. En este ejemplo ese virus y bacteria de omitir la letra e, es un proceso de autovacunación contra el aprendizaje de letras por separado que seguramente desarrollo su docente, en la medida que el pequeño comete este tipo de "errores" va avanzando en la comprensión del sistema de escritura con la ayuda del tiempo, de los letreros de las tiendas, de las revistas, de los paquetes de chitos, papitas y en el mejor de los casos, del profesor que le lee cuentos y le escribe palabras completas en el tablero.

En síntesis, el maestro, lejos de percibir las equivocaciones de los niños como una tragedia, debe tenderles una alfombra roja para que pasen y hagan su trabajo en el proceso natural infantil, en este caso específicamente en la comprensión de los procesos de lectura y escritura convencional. Evitar que nos niños hagan su propio proceso, es una estafa a la que han estado sometidos y lo continuarán estando mientras las prácticas y los discursos pedagógicos no sean resignificados y adaptados a los niños y a la sociedad actual.

\subsection{Cambios de paradigmas lingüísticos}

Todo lo hasta aquí descrito no se ha quedado en la simple teoría, durante 6 años fue llevado a la práctica con niña es entre los 4 y 7 años de edad. Intentaremos compartir los procesos más relevantes en términos teóricos y prácticos. Para realizar cosas diferentes en necesario pensar diferente, es ese sentido, el maestro lejos de buscar definiciones sobre el lenguaje debe rescatar su pluralidad e iniciar la búsqueda de otros caminos en el campo de la pedagogía del lenguaje que favorezcan y den centralidad en el acto educativo a los conocimientos y lenguaje con que llegan los niños al aula de clase y que han sido apropiados de su contexto familiar y social. Este cambio de paradigma no es posible si continuamos concibiendo las cuatro habilidades comunicativas desde la definición del diccionario tradicional, entre otros, Larousse o Norma. 
Por lo menos a partir de los años 90, el Ministerio de Educación Nacional publicó documentos de incalculable valor para la educación infantil. Comprender las cuatro habilidades comunicativas desde una perspectiva diferente a la planteada en los diccionarios, es una de las más relevantes porque nos hace menos ingenuos frente al lenguaje. Cada una de estas nuevas definiciones que podríamos enmarcar en un nuevo diccionario que podríamos llamar "Significación", amplía las posibilidades de comprensión del lenguaje infantil dotando se sentido y significado todo el bagaje que el pequeño ha construido en su interacción con los demás y con su entorno, aun cuando habitaba el vientre materno. Pensar que un niño puede leer y escribir desde las entrañas de su madre, resulta disparate para muchos y sensatez pocos, buscamos que funcione al revés. A continuación definiremos y analizaremos, desde los lineamientos curriculares de lengua castellana cada una de las cuatro habilidades comunicativas.

\subsection{Habilidades comunicativas. Virus y bacterias necesarias en la primera infancia}

Por lo menos a partir de los años 90, en Colombia la pedagogía del lenguaje se orientó, hacia un enfoque en el que el lenguaje tiene usos sociales, es decir, los niños usan el lenguaje primero con fines comunicativos y no como conocimiento dado su uso en situaciones reales de comunicación. El desarrollo de las cuatro habilidades: hablar, escribir, leer y escuchar se convirtió en el centro de los desarrollos curriculares. Sin embargo, muchos perdieron la pista (si fue la tuvieron alguna vez) y centraron en la instrumentalización el trabajo sobre las habilidades comunicativas, perdiendo de vista las dimensiones socio-culturales y éticas.

Estas otras definiciones sobre leer, escribir escuchar y hablar presentes en el diccionario que hemos denominado "Significación", harían que nos ocupemos de otras actividades y percepciones. Estas habilidades comunicativas se dan de manera sincrónica, relacionada e interdependiente, no es posible separarlas, sin embargo para una mejor comprensión intentaremos definirlas desde la significación con la claridad que no es el único sentido que es posible encontrarles, pero sí uno de los más apropiados hasta el momento. De acuerdo con los Lineamientos Curriculares de Lengua Castellana lo más importante en los primeros peldaños de la pirámide escolar es la liberación de la palabra por el niño, el fortalecimiento de su competencia comunicativa a nivel oral, para luego acceder a la necesidad de leer y escribir. Es claro que parte de esas primeras formas de expresión infantil son los dibujos, los mismos que van mutando y convirtiéndose en formas grafémicas hasta convertirse en escritura convencional. De la importancia de los dibujos habla Vygotsky en La imaginación y el arte en la infancia: 
El niño al dibujar, transmite en el dibujo todo lo que sabe sobre el objeto que representa y no solo lo que ve por so con frecuencia pinta cosas que no ve, y por el contrario faltan en su dibujo muchas cosas que ve sin duda alguna, pero que no le parecen sustanciales en el objeto que está dibujando (2005, p. 88).

Al igual que Vygotsky, las investigaciones de la estudiante directa de Piaget, Emilia Ferreiro han sido un referente obligatorio cuando de lenguaje y proceso de lectura y escritura se trata. En cada uno de sus escritos, esta importante pensadora argentina analiza desde diferentes frentes la relevancia de buenas prácticas que comprendan el trance de lo oral a lo escrito y lo leído. Leemos en Ingreso a la escritura y a las culturas de lo escrito. Textos de investigación:

[...] estos estudios abren la posibilidad de interpretar la relación oral escrito desde una perspectiva diferente, si la relación entre la escritura y las unidades del lenguaje que el niño se plantea al inicio de la fase de fonetización consiste en hacer corresponder las letras con las sílabas de las palabras que le escribe, las escrituras de la frase subsiguiente por muy incompletas que resulten no pueden considerarse deficientes, por el contrario, cualquier modificación de la escritura en el sentido de hacerse más alfabética constituye un logro para el niño Así pues las letras que se añaden a las sílabas anteriormente escritas con una sola revelan un avance en el análisis del lenguaje ya sea que estas letras sean utilizadas correctamente o tengan únicamente valor aproximado. Las omisiones sustituciones y demás "errores" puesto que no están precedidas por un análisis fonológico pleno reflejan más bien los esfuerzos de los niños por acercarse a un análisis de la clase (Ferreiro, 2013, p. 150).

Asignado protagonismo a los errores normales y necesarios, como hemos venido mencionado, Cabe mencionar que cuando se enseña a los niños letra por letra como desafortunadamente aun hacen muchos maestros, difícilmente los pequeños pueden pasar por estos niveles dado que la pedagogía que aplica el docente lo limita a la simple repetición y traslado de letras sin sentido del tablero al cuaderno. No se trata entonces de utilizar las letras como punto de partida sino, como punto de llegada. En esas condiciones el pun to de partida es el desarrollo de la oralidad a través de actividades como la narrativa. Leer cuentos y permitir la interacción de los pequeños a través sus hipótesis, mostrarles las palabras con sentido completo 
y en lo posible acompañado de imágenes, llevarlos al papel para que "escriban" lo que quieran, lo que recuerdan sobre el cuento narrado, resultan estrategias que determinan su compresión del sistema de significación (lectura y escritura). Ferreiro propone tres niveles del sistema de escritura que nos permitiría comprender el estadio o nivel en que se encuentra el niño y ayudarle a pasar por cada uno hasta que de manera autónoma descubra cómo funciona el sistema de lectura y escritura. Respetar el garabateo, las combinaciones e invención de formas que aunque para el adulto carecen de sentido, para los niños representan su mundo interior, dan la pista sobre su estado cognitivo, emocional y mental inclusive, todo lo cual nos obligaría a pensar "a mayor garabatero e invenciones, mayor información tenemos sobre cómo va sus procesos". En la medida que avanzan en sus garabateos, avanzan en la lectura porque son procesos que se dan de manera simultánea.

Después de narrar el cuento o la historia, se pide a los niños que recuerden y mencionen personajes o "amiguitos" del cuento, se procede a escribirlos en el tablero aclarando siempre cuál de ellos se está escribiendo, luego de escribir entre 2 y 10 palabras o personajes que ellos mismos han nombrado, se puede proceder a leerlos con la ayuda de los niños. En este momento del proceso, es necesario que el docente de tiempo a los niños de pensar y de hacer su propio proceso. Ejemplo: si uno de los personajes del cuento fue el perro, al leerlo en el tablero, el profesor inicia diciendo pe... dando oportunidad a los niños que terminen la palabra...rro. De esta forma el niño llega a comprender que lo que conoce como un perro (posiblemente su mascota o el perro del vecino o del barrio), se puede representar con letras. Finalmente, se solicita a los niños que en un papel el blanco, le "escriban" una carta a su personaje favorito, lo que escribió en el cuento, etc. Cuando los niños intentan llevar sus pensamientos y comprensiones al papel, es un momento sublime en el que el maestro puede "entrar a las cogniciones y sentimientos" de los niños, en otras palabras, ese trozo de papel representa la puerta a través de la cual es maestro ingresa a los procesos mentales generales construidos por el niño hasta ese momento y en particular los relacionados en torno a los procesos de lectura y escritura.

Esas cogniciones, lenguajes y pensamientos, son representados por los niños a través de líneas, imágenes, grafías convencionales o inventadas. Son estas representaciones las que Emilia Ferreiro nos permite comprender a través de los tres niveles del sistema de escritura, la sicogénesis de la lectura y la escritura. Gracias a éstos niveles de desarrollo del sistema de escritura en el niño propuestos por Ferreiro, podemos advertir y ubicar el estado de las cogniciones de los niños con respecto a la lectura y escritura en tres niveles por los que van atravesando los niños en la medida que van descubriendo el funcionamiento convencional de la lectura y la escrita. Se aclara que 
no todos los niños inician en el primer nivel, es decir, el más básico, dependiendo del ambiente familiar, social y cultural en el que se encuentra inmerso el pequeño, puede ubicarse a partir del segundo, e incluso en el tercero.

\subsection{Niveles de desarrollo del sistema de escritura en el niño}

Estos tres niveles han sido asumidos y planteados por el Ministerio de Educación Nacional a través de los lineamientos curriculares de lengua castellana. Leemos en los lineamentos mencionados entre las páginas 57 a la 60:

Se da la distinción entre dibujo (lenguaje icónico) y escritura (grafías) como formas de representación.

Los niños concluyen que lo que diferencia al dibujo de la escritura es la forma como se organizan las líneas; pues al fin y al cabo en el dibujo también se trazan líneas (se sigue un contorno).

\begin{tabular}{|c|c|}
\hline \multicolumn{2}{|c|}{$\begin{array}{l}\text { Aparecen dos pr } \\
\text { de los }\end{array}$} \\
\hline convencionales: & \\
\hline
\end{tabular}

Es decir, los niños descubren que las grafías (arbitrarias) se organizan de forma lineal y que las grafías no reproducen a los objetos, los representan.

Pero construir este principio no

significa apropiarse de los códigos convencionales. Hay unos primeros momentos en que el niño, bajo este principio, inventa formas grafémicas, mezcla éstas con las grafías
Aparece un control sobre la cantidad y la cualidad; en este sentido, se buscan diferencias entre escrituras que justifiquen interpretaciones diferentes. Es decir, ya no basta con que internamente las grafias sean distintas, se requiere que un conjunto de grafias sea distinto de otro conjunto para significar cosas distintas.

En el primer nivel, conjuntos de organizaciones iguales pueden significar diferente en momentos distintos; el niño puede asignar significados iguales sin variar el tipo de grafias ni su organización. En fin, los niños se enfrentan al problema de ¿cómo crear diferencias gráficas para significar cosas distintas? En este sentido, exploran tanto el principio cuantitativo como el cualitativo de manera separada o simultánea.

Por ejemplo, ponen a prueba hipótesis como: a objetos de mayor tamaño o edad, mayor número de grafias. Por ejemplo, para nombrar la hormiga se requieren pocas letras, para nombrar el elefante se requieren muchas; para nombrar al abuelo se requieren muchas letras, para nombrar al niño se requieren pocas. También ponen a prueba hipótesis como la cantidad máxima: para que una palabra signifique algo no debe tener menos de tres grafias ni más de siete.

En este momento se está trabajando sobre el significado de la palabra o la frase en su globalidad. La relación es cadena de grafias/significado:
Aparece de manera explícita la relación entre sonido y grafia. Es decir, se llega a la fonetización de la representación escrita. Digamos que hasta este punto se ha trabajado la necesidad de simbolizar, a través de representaciones gráficas (letras), un significado, una realidad. Ahora es necesario trabajar la relación entre esa representación gráfica y el componente fonético. Aparecen tres hipótesis en niños hispanohablantes: silábica, silábicoalfabética y alfabética.

Ya hay un trabajo sobre la cantidad y la calidad a un nivel más complejo. Por ejemplo con el nombre propio. ¿Por qué esas letras y no otras? ¿Por qué tantas y no tantas? Aparece la necesidad de crear un mayor control sobre la cantidad y la calidad, que satisfaga sus preguntas: letras similares para segmentos sonoros similares.

Aparece el problema de la fonetización así no se resuelva en términos silábicos convencionales.

Los niños acceden a la hipótesis silábica de forma distinta. Algunos controlan la producción de manera cuantitativa, escriben tantas letras como sílabas. Otros reconocen algunas letras como asociadas a sílabas particulares. Los niños eligen una letra para un fragmento sonoro de la palabra, y generalmente esa letra es una vocal, debido a la presencia regular de éstas en la lengua española. Los niños hispanos prefieren las vocales. En muchos casos se tiende a utilizar la letra inicial del nombre con un valor silábico. M de Martha como ma... En fin, el niño busca letras similares para representar fragmentos sonoros similares, aunque la letra seleccionada no corresponda fonéticamente. 


\begin{abstract}
convencionales que en el espacio socio-cultural va reconociendo, apropiando. va

El niño descubre que es mejor aceptar las grafías existentes que las inventadas, por

exigencias sociales de comunicación; y en sus producciones incluyen cadenas de letras: letras repetidas, escritura ligada, trazos continuos. En este nivel se termina por considerar las cadenas de letras como objetos sustitutos.

Se encuentra la limitación del dibujo en el sentido de ser incapaz de decir el nombre de los objetos. Bajo este

propósito, se comienzan a problematizar las características de la escritura para que signifique el nombre del objeto.
\end{abstract}

Aparecen aquí dos hipótesis: cuantitativa $y$ cualitativa.

¿Cuántas letras debe tener una escritura para que sea legible?

¿Cuántas letras debe tener un nombre para ser legible?

Los niños hispanohablantes dicen que tres: "Si hay tres letras ordenadas de modo lineal, ahí debe decir algo" hipótesis de cantidad mínima. diferencias en la organización, características de las cadenas (palabras frase). No hay fonetización aún. Es decir, no hay relación sonido/grafia Significado y significan-te constituyen una sola unidad.

En este nivel, el niño explora posibilidades cualitativas: varía el repertorio, varía la posición.

En este punto aparecen diferentes posibilidades: si el niño cuenta con un menú reducido, se pueden mantener unas grafias fijas (la primera, la última) y variar otras. Si el niño cuenta con un menú amplio de letras, a palabras diferentes, letras diferentes.

Con un menú amplio, organizaciones diferentes corresponden (deben corresponder) a significados diferentes. Si el niño cuenta con un menú reducido, busca obtener significados diferentes variando la posición de las grafias; ésta es la solución más compleja que se encuentra en este nivel; lo mismo que la combinatoria de variaciones cualitativas y cuantitativas de manera simultánea.

En estas soluciones muy elaboradas ya se evidencia un principio sintáctico claro, se ha construido un complejo sistema de variaciones que permite establecer interrelaciones (relaciones entre conjuntos o cadenas de grafias). También se puede hablar de reorganización cognitiva, ya que las formas de operar del pensamiento van apareciendo simultáneamente con este trabajo.

Hasta este punto se ha avanzado hacia la construcción de principios que regulan el sistema, y las relaciones y complejidades entre estos principios; pero aún no se ha llegado a la fonetización; es decir, a la relación (alfabética) entre el sonido de una palabra y su escritura.
Lo que interesa es que el niño ya asocia la pauta sonora con la selección de las grafias; esa relación sonido/grafia es lo que marca la hipótesis silábica. Otro aspecto cognitivo relevante en este punto es que se problematiza la relación entre el todo y las partes.

En otro momento del proceso aparece la hipótesis silábico alfabética: unas letras ocupan el lugar de sílabas (conjuntos de sonidos), y otras ocupan el lugar de fonemas (sonidos aislados).

Finalmente se llega a la hipótesis alfabética: a cada sonido corresponde una grafia. Aquí lo importante es el principio que se ha construido, que es un principio de control cognitivo de la calidad y la cantidad, esto interesa más que la forma de la escritura. Aparecen problemas como la representación poligráfica de fonemas $(/ \mathrm{s} /=\mathrm{ci}=\mathrm{si})$, los espacios en blanco, los signos de puntuación, las mayúsculas. Se ha construido un principio elemental: a similitud sonora, grafias similares; a diferencias fonéticas, letras diferentes. Ese es el principio fundamental de las escrituras alfabéticas.

De aquí en adelante el reto es avanzar en la construcción de los demás principios complejos del sistema de escritura: la sintaxis, la segmentación semántica de unidades, las reglas ortográficas. Podríamos decir que, por esta razón, a nivel didáctico, este enfoque es más complejo que uno que comience el proceso de acercamiento a la lengua escrita desde la fonetización: letras... silabas... combinaciones... palabras... El asunto es comprender que en la marcha natural de construcción de la lengua escrita por el niño, la fonetización es punto de llegada y no de partida. Y que ésta ha sido la historia cultural filogenética de la escritura.

$\mathrm{Y}$, ¿qué papel juega el desarrollo motriz fino (agilidad de la mano para desarrollar los trazos, seguir contornos...) en el proceso de construcción del sistema de escritura? Vygotsky dice: una cosa es la mano y otra es el cerebro; el desarrollo de la simbolización no se deriva del desarrollo motriz. El trabajo central de la escuela es sobre la simbolización,

Fuente: Lineamientos Curriculares de Lengua Castellana-MEN 


\section{HIPÓTESIS}

Las siguientes hipótesis, tanto las generales como las específicas pretenden provocar a los lectores y en el mejor de los casos servir como punto de partida a nuevas exploraciones investigativas.

\subsection{A manera de hipótesis generales}

- El temor de algunos maestros por innovar, hace que los pequeños naufraguen en procesos descontextualizados que funcionan de manera arbitraria con su condición infantil.

- La educación apuesta por la trasformación de la sociedad a partir de la trasformación del individuo.

- El papel del educador no se limita a aplicar la norma, sino que, además, debe ser, un artista, un actor, un mago (Borges).

- Si tenemos un cerebro triuno de acuerdo con MacLean, si la inteligencia es múltiple, de acuerdo con Gardner, es necesario superar el racionalismo reduccionista, conectando la razón con la emoción

- Resulta perentorio reivindicar el protagonismo de lo emocional en un mundo que se deshumaniza cada vez más a partir de la razón instrumental.

- ¿Cómo mantener la dinámica entre razón y emoción sin que se desborde de uno de los extremos? Se requiere un profesor atento a la ocasión (kairós) y con disponibilidad (Jullien).

- La educación y la sociedad son un campo de batalla en donde se enfrentan lo apolíneo (representado por la razón sin emoción, que se queda en simple contemplación) y lo dionisíaco (el peligro que representan las emociones al margen de la razón).

- ¿Qué hacer con los agelastos? (del griego A: sin, gelastos (reír, es decir, los que no ríen) Probablemente no mucho, pero se puede hacer con los niños y adolescentes y esperar resultados en el futuro.

- Publicistas, poetas, sacerdotes y políticos acuden a la emoción, al tiempo que los profesores la reprimen. 
- Ubicuidad de la emoción: consumo emocional (Lipovetsky) y el lenguaje cotidiano.

- En las prácticas pedagógicas liberadoras y participativas, el hombre no es solo razón, sino, además, emoción.

- Para trascender el modelo de la universidad profesionalizante, no solo es necesario investigar, sino, además, humanizar.

- Contrarrestar el déficit motivacional de las éticas cognoscitivas a través del cine y el teatro.

- Si tenemos diferentes tipos de inteligencia, de acuerdo con Gardner, ¿por qué continuar perpetuado la Pasofia (Comenio) de acuerdo con la cual se enseña todo a todos a través de un mismo método?

- Si además de un cerebro tenemos tres de acuerdo con MacLean, ¿por qué en la educación el protagonista continúa siendo el racional a pesar de ser el menos desarrollado?

\subsection{A manera de hipótesis específicas}

- Cuando se enseña letra por letra, nos niños no pasan por los tres niveles del sistema de escritura porque no se da la construcción y movilización de pensamiento infantil, solo se limitan a la repetición sinsentido.

- Los niveles del sistema de escritura formulados por Emilia Ferreiro, nos permiten comprender el "estado" en que se encuentran sus comprensiones y actuar en consecuencia.

- Los niños en esta metodología "natural", lejos de ser sujetos pasivos y silenciosos, se busca que vivan paso a paso su propio proceso y descubrimientos y participen y conversen con sus compañeros, toda vez que solo cuando interactuamos con los demás, podemos confrontarnos a nosotros mismos e internalizar conocimientos (Vygotsky).

- La zona de desarrollo próximo es el escenario adecuado para promover el paso de las funciones mentales inferiores a las superiores, para la internalización y pasar de la zona de desarrollo real a la de desarrollo potencial. 


\section{Conclusiones}

- Si los últimos avances científicos y el Ministerio de Educación Nacional a través de los Lineamientos Curriculares de Lengua Castellana dan cuenta del anacronismo de enseñar letra por letra y de las bondades de enseñar palabras con sentido completo y en contexto, ¿por qué en las aulas de clase de los niños, la mayor parte de los maestros continúan gestando el primero en detrimento del segundo? Docentes que repiensen sus discursos y prácticas pedagógicas y programas que formen maestros en estos avances, resulta inaplazable.

- Si la oralidad es el punto de partida y las letras el punto de llegada en el proceso natural de aprehensión de la escritura y la lectura, resulta menester aprovechar los conocimientos que los niños construyen a lo largo de su vida y utilizarlos como materia prima en el aula de clase, esto no solo hace niños más felices y seguros sino que, además, facilita el trabajo del docente y permite a todos sus actores avanzar de manera exponencial.

- El juego y la imaginación deben gozar de protagonismo en la educación infantil, reprimirlos es un pecado capital al igual que ignorar el poder de la narrativa y la literatura infantil para desarrollar oralidad, desencadenar procesos mentales superiores y favorecer la transversalidad entre todas las áreas del conocimiento.

- El Socioconstructivismo rescata el poder de la interacción y del trabajo en equipo a través de la zona de desarrollo próximo, el incorrecto uso de las TIC obliga a la individualidad, dar un uso socioconstructivista a las TIC que rescate además la ciudadanía desde la primera infancia, sería la clave, entre otras cosas para reemplazar emociones negativas como la envidia por emociones positivas como la emulación.

- Las emociones positivas y su conexión con la razón, constituyen la vía por excelencia para superar el déficit motivacional de las éticas cognoscitivas. Es menester sacar partido de las diferencias en vez de hacer vanos esfuerzos por reprimirlas, en concordancia con Maturana.

- Enseñar a leer y escribir de manera tradicional (letra por letra) funciona, de hecho somos sus hijos, sin embargo, no es el método más apropiado porque enseña por fuera de contexto, ignora la condición infantil, hace niños infelices y subvalora los conocimientos que los niños aprenden de su entorno familiar, social y cultural haciéndolos sentir forasteros de su propio proceso. 
- Los supuestos "errores" de los pequeños lejos de ser percibidos como retrasos, evidencian los avances y el estar atravesando etapas de desarrollo cognitivo. Enseñar en contexto, vacuna contra la enfermedad moderna, "evitar pensar". 

CAPÍTULO II 



\title{
EDUCACIÓN PARA LA CIUDADANÍA. CONTEXTO SOCIO HISTÓRICO
}

\author{
Nancy Palacios Mena
}

\section{LA EDUCACIÓN PARA LA CIUDADANÍA Y LA DEMOCRATIZACIÓN DE LA ESCUELA EN COLOMBIA CONTEXTO SOCIOHISTÓRICO}

Este capítulo es una reconstrucción de las condiciones socio históricas en las que emerge la necesidad explícita de educar para la democracia y la ciudadanía en Colombia. En él se analiza el origen y el contexto del proceso de democratización de la escuela colombiana en el periodo comprendido entre 1990-2005. El capítulo se ha dividido en seis partes: las tendencias educativas del contexto internacional, la situación de violencia y reforma constitucional que vivió el país, la categorización de la escuela como un espacio antidemocrático y reproductor de la violencia, las posturas que orientaron la democratización de la escuela y la formación ciudadana, las reformas en el currículo y en la organización social escolar. Cada una de las partes del capítulo va acompañada de un esquema que recoge y sintetiza las principales ideas planteadas en él.

\subsection{Las tendencias educativas del contexto internacional}

Ha sido una tradición que gran parte de las reformas, planes y programas que en materia de educación se han ejecutado en el país, tengan su origen en políticas internacionales, bien porque son exigencias del sistema financiero como parte de los requisitos para el préstamo de recursos económicos que permitan hacer inversiones en educación, o bien, porque son compromisos que Colombia adquiere en calidad de miembro de organismos internacionales como la UNESCO. Así, las reformas 
que se implementaron desde finales de los años 80 y 90 en Colombia y en otros países de la región, tuvieron su origen en la necesidad de responder a los retos que imponía un nuevo orden político, social y económico internacional. Álvarez (2001) lo plantea de la siguiente manera:

Después de la segunda guerra mundial los países capitalistas se organizaron para tener control sobre una región muy grande del mundo, para ello impulsaron un conjunto de planes y programas que se llamaron políticas de desarrollo. Desde entonces todo comenzó a llamarse así. Se trataba de una estrategia que hacía parte de la guerra fría, en la que nuestros países comenzaron a ser considerados subdesarrollados. Uno de los asuntos sobre los cuales el desarrollo se centró fue el de la educación. Desde entonces este tema no sería cuestión de los Estados Nacionales, sino de una estrategia mundial que debía garantizar que la población de esta parte del mundo pensara y actuara de acuerdo con las necesidades de dicha estrategia. Es decir, la educación dejo de ser nacional y pasó a ser un asunto mundial. La institución escolar: los planes curriculares, los textos escolares, los métodos pedagógicos, los sistemas de evaluación de estudiantes, los reglamentos y normas, todo comenzó a ser reformado a partir de las orientaciones que los organismos internacionales hacían para nuestros países (p. 18).

Las reformas fueron vistas como la posibilidad de plantear nuevas estrategias para intentar superar las constantes crisis sociales y estar a tono con las circunstancias internacionales, lo que se traduce en estar en condiciones de competencia frente a los grandes bloques, o como la oportunidad de participar en las dinámicas de construcción de un nuevo orden político social y económico internacional (Caballero, 1994). Los países que implementaron reformas educativas, desarrollaron estrategias pedagógicas acordes con las transformaciones deseadas y establecieron mecanismos jurídicos que permitieran reestructurar el sistema educativo, la asignación de recursos para poner en marcha la reforma, y, fundamentalmente, la expresión de una voluntad política que apoyara y posibilitara la propuesta. 
Gráfica $N^{\circ} 1$. Las tendencias educativas en el contexto internacional

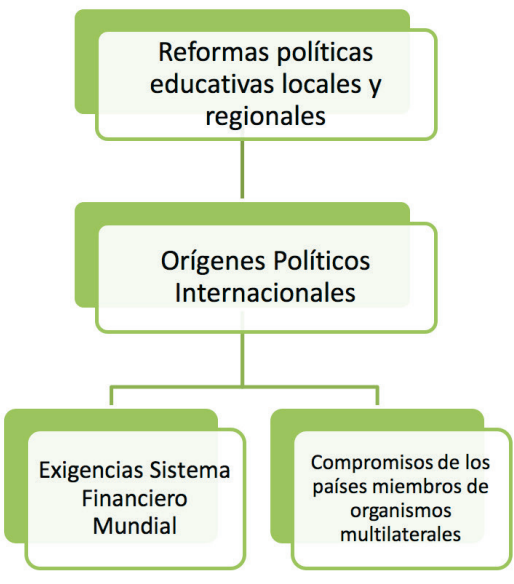

Reformas

Necesidad de responder a los retos que imponía nuevo orden político - social económico
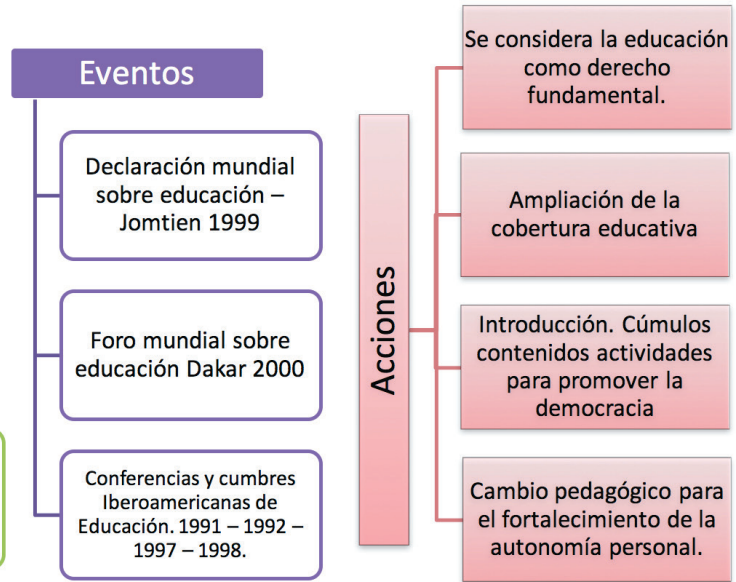

Masificación de la educación, paso importante en la búsqueda de mecanismos para llevar a la escuela principios y valores democráticos

A continuación se subrayan algunos de los aspectos que determinaron la dirección de la política internacional en educación entre 1990 y 2005. Se trata de algunas declaraciones, en su mayoría producto de congresos y conferencias en las que Colombia participó. Uno de los temas comunes en estos eventos fue el de la masificación de la educación como una necesidad para fortalecer la democracia, reducir la pobreza y las desigualdades sociales. Por tales razones se ratificó la educación como un derecho fundamental: la Declaración Mundial sobre la Educación para Todos, celebrada en Jomtien, Tailandia, entre el 5 y el 9 de marzo de 1990, dice:

Recordando que la educación es un derecho fundamental para todos, hombres y mujeres, de todas las edades y en el mundo entero.

Reconociendo que la educación puede contribuir a lograr un mundo más seguro, más sano, más próspero y ambientalmente más puro y que al mismo tiempo favorece el progreso social, económico y cultural, la tolerancia y la cooperación internacional.

Conscientes de que la educación es una condición indispensable, aunque no suficiente para el progreso personal y social, proclamamos lo siguiente: 
Art. 7.-Las autoridades nacionales, regionales y locales responsables de la educación tienen la obligación prioritaria de proporcionar educación básica.

Art. 8.-Es necesario desarrollar políticas de apoyo en los sectores social, cultural y económico para poder impartir y aprovechar de manera cabal la educación básica, con vistas al mejoramiento del individuo y de la sociedad. La sociedad debe proporcionar además un sólido ambiente intelectual y científico a la educación básica (pp.1-2).

Los acuerdos firmados en Jomtien fueron ratificados en el Foro Mundial sobre la Educación, celebrado en Dakar, Senegal, del 26 al 28 de abril del año 2000; los participantes en el Foro apoyaron el planteamiento de la educación básica como derecho fundamental reconocido en la Declaración Universal de los Derechos Humanos y contrajeron el compromiso de llevar educación "a todos los ciudadanos y todas las sociedades". Para lograrlo, acordaron que los estados debían consolidar o crear planes de acción que apostaran especialmente a la primera infancia, a la salud en la escuela, a la educación de los niños y las mujeres, a la alfabetización de adultos y a la educación en situaciones de crisis.

En el marco de acción de Dakar, "Educación para todos", se consideró que niños, jóvenes y adultos, en su condición de seres humanos, tienen derecho a beneficiarse de una educación que satisfaga sus necesidades básicas de aprendizaje, una educación que los ayude a vivir con los demás, "una educación orientada a explotar los talentos y capacidades de cada persona y desarrollar su personalidad para que mejore su vida trasforme la sociedad" (p. 3). El marco de acción de Dakar concluyó que la educación era un derecho fundamental y, como tal, un elemento clave del desarrollo sostenible y de la paz y estabilidad de cada país.

Además de la ampliación de la cobertura educativa como un paso importante en el fortalecimiento de la democracia, anteriormente mencionada, la búsqueda de mecanismos para llevar a la escuela los principios y los valores democráticos, fue el tema central de otros eventos internacionales en los que Colombia también participó en la década de 1990: la II Conferencia Iberoamericana de Educación 1992, la VII Conferencia Iberoamericana de Educación, la Cumbre iberoamericana de Isla Margarita en 1997, y la VIII Conferencia Iberoamericana de Educación en 1998. 
A la II conferencia Iberoamericana en Guadalupe, España, en 1992, asistieron los ministros de Educación del área y declararon:

Queremos resaltar la especial relevancia del papel que la educación debe desempeñar al servicio de una comunidad que «se asienta en la democracia, el respeto a los derechos humanos y las libertades fundamentales» y que se compromete «con el desarrollo económico y social de nuestros pueblos, la plena vigencia de los derechos humanos, la ampliación de los cauces democráticos, el fortalecimiento de nuestros sistemas institucionales y el respeto a los marcos de derecho internacional». Asimismo, queremos destacar la afirmación contenida en dicha Declaración de que «la contribución al fortalecimiento de la democracia en nuestra región» se debe vincular con el compromiso para conseguir «el acceso general a servicios mínimos en las áreas de salud, nutrición, vivienda, educación y seguridad social» (p. 1).

Los ministros reunidos en Guadalupe, dijeron estar convencidos de que los fundamentos éticos de la democracia y su ejercicio efectivo, así como el desarrollo económico y social, tenían en la educación un instrumento fundamental. La educación y la cultura, como elementos que conforman profundamente nuestras sociedades, debían contribuir a la consolidación de comunidades más libres, prósperas y solidarias en el espacio iberoamericano. Para cristalizar estas intenciones se propusieron algunas acciones que apoyaran los procesos democráticos en la educación: acompañar experiencias que propusieran como objetivo principal vincular la educación con la sociedad y propiciar un mayor equilibrio en la participación de los diversos actores del quehacer educativo, promoviendo, de manera especial, aquellas que fomentaran la participación de los representantes sociales en la discusión de los contenidos de la enseñanza y en la gestión de los centros educativos, e introducir en los currículos objetivos, contenidos y actividades de aprendizaje que promovieran la educación para la democracia y fomentaran la conciencia y la participación ciudadana en el respeto a los derechos humanos y en la conservación del medio ambiente y de los recursos naturales.

Para proponer líneas de cooperación en la educación y los valores éticos para la democracia se reunieron los presidentes de varios países de Iberoamérica en Mérida, Venezuela, en 1997. Según la declaración final del evento el objetivo de los mandatarios era fortalecer la democracia, el respeto, la defensa y la promoción de los derechos humanos. Se requerían desde el Estado políticas y acciones de orden social y económico que posibilitaran a los ciudadanos resolver sus necesidades básicas y transformar situaciones de inequidad, violencia, impunidad y corrupción. 
Igualmente eran necesarias políticas y acciones educativas, no solo para la escuela, sino también para la sociedad en su conjunto: los medios de comunicación, la familia, los gremios empresariales, los profesionales, los líderes sociales y los trabajadores.

La escuela debía integrar en su cotidianidad, y no solo en los documentos legales que la regulan, valores propios de una comunidad democrática equitativa y justa, basados en derechos y deberes de sus miembros para una convivencia respetuosa y feliz. La escuela también debía integrar espacios en los que la reflexión, el debate y la propuesta de acuerdos estuvieran abiertos a la participación de las generaciones más jóvenes. Finalmente, era evidente la necesidad de exigir la construcción de un currículo que tuviera contenidos informativos, procedimentales y actitudinales, y que permitiera la transformación de las relaciones interpersonales en el espacio del aula y de la escuela. Esta consideración debía recrearse en el caso de los estilos docentes no verticales y en los que estuvieran presentes el uso de tecnologías de la comunicación de forma tal que éstos integraran sistemas interactivos que facilitaran la comprensión crítica y el aprendizaje significativo.

En la misma línea anterior, y para reflexionar sobre los valores éticos y la democracia, se celebró la Cumbre de Isla Margarita meses después de la reunión de Mérida. El asunto central de la reunión fue la ratificación de los compromisos de los países con la defensa de la democracia, el Estado de derecho, el pluralismo político, las libertades fundamentales y los derechos humanos, los principios de soberanía y de no intervención, el derecho de cada pueblo de construir libremente, en paz, estabilidad y justicia su sistema político y sus instituciones, y la existencia de un sistema justo de relaciones internacionales éticas, democráticas en condiciones de paz y seguridad, en un marco de respeto a los principios de convivencia internacional consagrados en la Carta de las Naciones Unidas.

Los asistentes dijeron estar convencidos que la democracia era no solo un sistema de gobierno, sino también una forma de vida a la que los valores éticos dan consistencia y perdurabilidad. Además ratificaron su voluntad de continuar fortaleciendo y perfeccionando sus sistemas democráticos, de progresar cada vez más en el respeto y protección a los derechos humanos, de garantizar el respeto al Estado de derecho y lograr un óptimo equilibrio entre equidad y eficiencia en nuestros sistemas económicos para buscar la justicia social, mejorar nuestros sistemas de administración de justicia y elevar el nivel de la ética pública.

El ciclo de Conferencias Iberoamericanas de Educación, que tenía como fin aportar al fortalecimiento de la democracia en los países miembros, se cerró en 1998 con 
la VIII Conferencia Iberoamericana de Educación en Sintra, Portugal. En esta oportunidad, la conferencia se realizó para proponer líneas de cooperación en la educación y analizar específicamente lo relacionado con el tema globalización, sociedad del conocimiento y educación. Las propuestas finales de la conferencia fueron recuperar el papel del ser humano como actor principal del proceso educativo mediante una acción pedagógica basada en la razón dialógica y tendiente a la construcción autónoma de la personalidad, continuar los esfuerzos orientados a elevar el nivel de calidad de los sistemas educativos, garantizando por medio de la pertinencia y la flexibilidad de los currículos una sólida formación básica de ciudadanos responsables, solidarios, competentes y con capacidad suficiente de adaptación a los cambios. Además, privilegiar en las reformas educativas el cambio pedagógico orientado a una transformación en el aula y en la organización de la escuela, con el objeto de producir una permanente capacidad de aprendizaje y un fortalecimiento de la autonomía personal en sus dimensiones cognitivas, afectivas y morales.

\subsection{Violencia y Reforma Constitucional}

El clima de violencia de los años 80 , agudizado en los 90 con el recrudecimiento del conflicto armado, el impacto del narcotráfico, la multiplicación de los secuestros, masacres, extorsiones y tomas armadas, así como el creciente aumento de la corrupción administrativa en las instituciones del Estado y de la empresa privada, son los antecedentes y detonantes de una serie de reformas políticas que se llevaron a cabo en el país y que tuvieron como máxima expresión la proclamación de la Constitución Política de 1991. 
Gráfica 2. Violencia y reforma constitucional

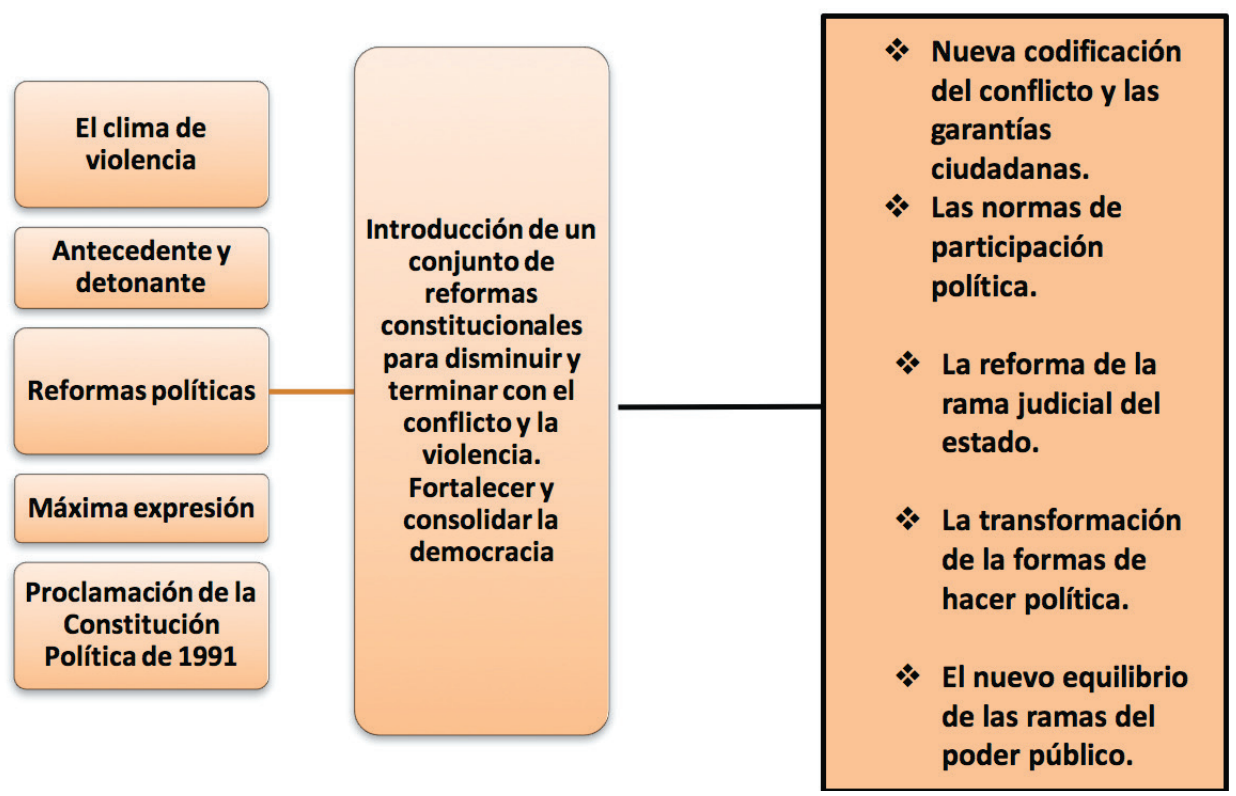

Las palabras del Ministro de Educación en la instalación del Seminario Internacional de Educación y Ciudadanía dejan ver el impacto de la violencia en la sociedad colombiana a finales del siglo XX y principios del siglo XXI:

Engendramos una cultura donde el individualismo y la intolerancia han determinado cómo desbordar el sentido de lo colectivo y el respeto por los demás. Ciudadanos transgresores por principio, que todo lo justifican. En nombre de la democracia estamos acabando con la democracia, en nombre de la participación ciudadana estamos acabando con la participación ciudadana: "la democracia y la participación, si responden a mis intereses", pareciera ser la consigna patria. Es la sustitución del contrato social por el capricho individual: la muerte a golpes de lo que resta de institucionalidad (MEN, 2001, p. 4).

Tal y como señalan Peláez y Márquez (2006), numerosos grupos armados intentaron desestabilizar el Gobierno colombiano en la década de 1980 y 1990; el incremento de la violencia política, la participación y el escalonamiento por parte de los actores armados, evidenciaron la ineficacia de los mecanismos estatales diseñados para mantener el orden. Entre 1988 y 1991, Colombia vivió una de las más profundas 
crisis sociales e institucionales de su historia, solo comparable con lo que fue el periodo de la violencia en los años 50: como afirma Valencia (1998) en su obra "Violencia en Colombia, años ochenta y reforma constitucional", es este contexto de violencia el que abre paso a la convocatoria a una Asamblea Nacional Constituyente orientada a poner fin a la crisis: "la justificación fundamental era poner fin al periodo de violencia, a la inseguridad y a la delincuencia, a través de la transformación de los instrumentos constitucionales de acción gubernamental o de la ampliación del espacio político" Valencia (1998, p. 57).

Si bien los actores políticos que lideraron el proceso de reforma constitucional eran de origen diverso y en algunos casos de ideologías divergentes, todos compartían la apuesta por la finalización de la crisis de violencia que se vivía en el país desde hacía varias décadas y que había llegado a su punto máximo entre 1989 y 1990:

Para un sector se trata fundamentalmente de reforzar los mecanismos de que dispone el Estado para hacer frente a la violencia en todas sus manifestaciones. Las prioridades de este proyecto de reforma eran la transformación de la organización de la justicia, con el fin de combatir la impunidad, y el afinamiento de los mecanismos de excepción de que dispone el ejecutivo para hacer frente a la situación de conflicto.

Para otro sector, el más importante factor que origina la violencia es el cerramiento del sistema político, la existencia de una democracia restringida, que al no ofrecer iguales posibilidades de participación a los diferentes actores los obliga a permanecer al margen del sistema y a apelar a medios violentos de intervención. Se trataba entonces de crear espacios de solución política de los conflictos, que desmotivara el recurso de la violencia como medio privilegiado para hacer política (Gallón y Uprimny, 1990, p.37; citados por Valencia, 1998, p. 37).

Así pues, entre 1990 y 1994 se produjeron cambios profundos en el ordenamiento jurídico del país. Como señala Manrique (1994), la Constitución de 1991 abrió la puerta mental al país para realizar reformas a las cuales se había opuesto resistencia. Para Valencia (1998), son cinco el conjunto de reformas constitucionales que se introdujeron como instrumentos privilegiados para disminuir, y posteriormente terminar el conflicto violento: la nueva codificación de los conflictos y las garantías ciudadanas, el establecimiento de mecanismos que garantizan su realización efectiva, las normas de participación política en los más diversos ámbitos, la reforma de la rama judicial del Estado, la transformación de la forma de hacer política y el nuevo equilibrio entre las ramas del poder público. 
En consecuencia, lo que puso en marcha la reforma constitucional fue un ambicioso plan para erradicar la violencia y fortalecer la democracia en el país. Por tal razón, en la nueva Constitución Política la educación estaría en el centro del desarrollo de la nación. Los cambios que se realizaron en la estructuras del Estado obligaban a redefinir lo educativo en la sociedad (Álvarez, 2001). Posturas como las de este autor sugerían que difícilmente la escuela y la educación podían escapar y ser ajenas al clímax social y político y sus aspectos más neurálgicos: la violencia, la crisis de valores y la violación reiterada de derechos humanos. Es así como a partir de la década del 90 el tema de la ciudadanía adquiere una gran importancia en la agenda política del gobierno colombiano, y la educación un lugar especial, por cuanto ella fue considerada un factor determinante en el desarrollo de las naciones y como elemento constituyente de la democracia (Pinilla y Torres, 2006).

Como un mandato constitucional se promulgó la ley 715 de 1994, o Ley General de Educación, con la cual se reglamentó el sistema educativo del país, se dio paso al surgimiento de importantes propuestas y programas de educación para la democracia, los derechos humanos y la paz, tendientes a legitimar el orden institucional y fortalecer las prácticas de convivencia pacífica en las escuelas. En el trasfondo de la nueva ley de educación persistía la idea de que la educación ciudadana estaba llamada a articular a todos los actores del proceso educativo alrededor de una misma causa y formar a un nuevo ciudadano amante del país, de sus instituciones y cumplidor de las normas. La intención quedó expresada en las memorias del Seminario Internacional de Educación Ciudadana celebrado en el 2001:

Educar para la tolerancia empieza por educar en el respeto a la ley. Colombia jamás será un país viable si no aceptamos unas reglas mínimas de juego. El problema de los colombianos es que cada cual anda en su propio código de normas debajo del brazo y cree a ciencia cierta que ella prima sobre la Constitución. Olvidamos que vivir en sociedad implica límites, restricciones a la libertad, empezando por observancia de los semáforos. Somos expertos en desconocer o torcerle el cuello a la ley, en acomodarla a nuestros designios. Lo más parecido a una seudo-anarquía por consenso (sic) (MEN, 2000, p. 5).

Según Peláez y Márquez (2006), los movimientos populares que promovieron y participaron en la promulgación de la Constitución de 1991 lograron incorporar en el nuevo texto diferentes conceptos que ampliaron la ciudadanía y, por lo menos en la retórica, aumentaron el espectro de la democracia y los derechos fundamentales. 
El establecimiento de un nuevo orden institucional inevitablemente trasformó los contenidos que debían enseñarse en las clases de educación cívica y también obligó al Estado a divulgar los nuevos contenidos de la constitución, incluidos los mecanismos para la defensa de los mecanismos de participación directa en la política. La educación también debía contribuir al propósito nacional de formar un nuevo ciudadano, más productivo en lo económico, más solidario en lo social, "más participativo y tolerante en lo político: más respetuoso de los derechos humanos y por lo tanto más pacífico en sus relaciones con sus semejantes, más consciente del valor de la naturaleza, integrado en lo cultural por lo tanto más orgulloso de ser colombiano" (Caballero, 1994, 26); así pues, la Ley General de Educación estableció como un objetivo prioritario de la estructura educativa el que los colombianos se apropiaran de los valores de la democracia y el respeto por los derechos humanos.

\subsection{La escuela violenta y antidemocrática}

Las situaciones antes planteadas dieron origen a la emergencia de una serie de discursos sobre la crisis en la que el país estaba atrapado a causa de la violencia. "El diagnóstico de una crisis generalizada fue elaborado desde distintos lugares, los analistas coincidieron en señalar que la crisis era específicamente de valores" (Cortés, 2012, p. 55).

Gráfica 3. La escuela violenta y antidemocrática

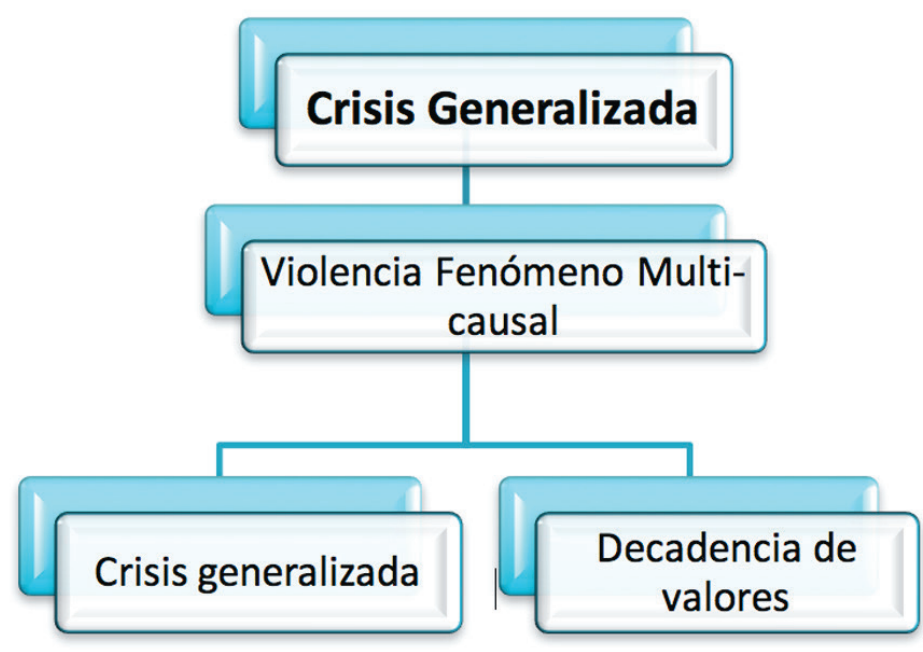



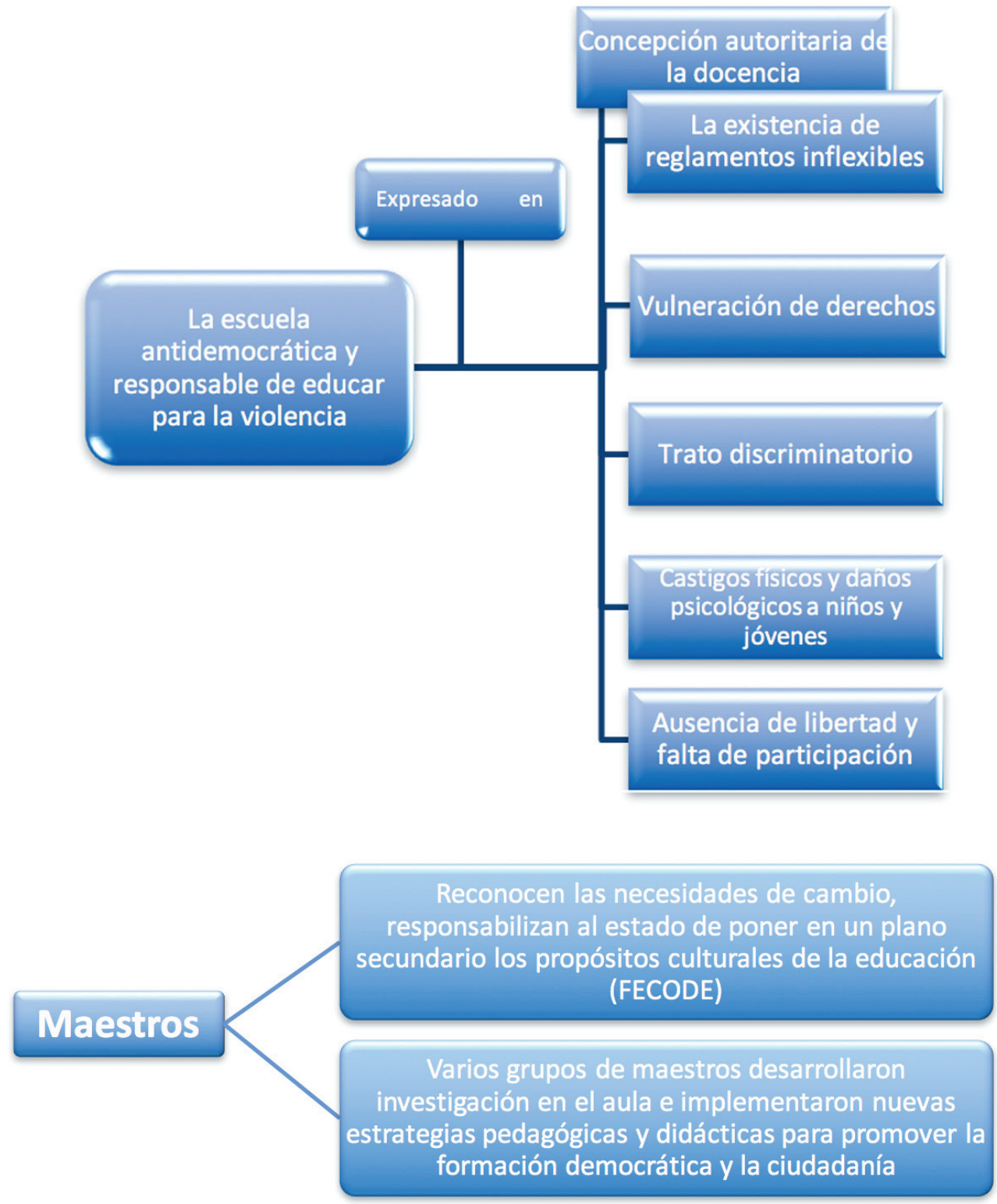

Entre los autores de estos discursos se encontraban investigadores académicos, casi todos vinculados a la vida universitaria, que explicaban la violencia en el país como un fenómeno multicausal, complejizado por la aparición de escuadrones de la muerte, 
bandas de sicarios, grupos de autodefensas campesinas o de justicia privada, los asesinatos sistemáticos de sindicalistas, la ofensiva guerrillera en el contexto urbano, el narcotráfico y la denuncia internacional de abusos de autoridad vinculados con los derechos humanos (Sánchez, 2009). Según Cortés (2012), los resultados de las investigaciones de los intelectuales como Gonzalo Sánchez, Álvaro Tirado Mejía, Jaime Arocha y Carlos Eduardo Jaramillo, fueron presentados al Ministerio de Educación y además publicados en una cartilla, dirigida a los maestros del país.

La publicación de la cartilla y otros documentos en esta misma línea, desencadenó reacciones como las del Ministro de Educación de la época, Manuel Francisco Becerra, quien señaló a la escuela de antidemocrática y en parte responsable de educar para la violencia. En palabras del Ministro, "la escuela era un escenario antidemocrático en la que la concepción autoritaria de la docencia y la existencia de reglamentos inflexibles trae consigo el desapego por las prácticas de convivencia pacífica" (MEN, 1989, p. 17). En el mismo sentido, Álvaro Tirado Mejía, también autor del informe que da origen a la cartilla, enfatizaba en que la cultura violenta que afrontaban los colombianos, tenía sus raíces en una formación autoritaria en la familia y en la escuela, porque el autoritarismo era una característica presente en la actitud de los adultos hacia los niños, de los hombres hacia las mujeres, y en general, de los más poderosos hacia los débiles (MEN, 1989).

Los estudios en mención coincidían en que una de las principales expresiones de la violencia en la escuela era la vulneración de derechos; en un trabajo titulado "La escuela y los derechos humanos", Zafra (1998), enfatizaba en que la escuela estaba convirtiéndose en una negación a todo lo que sonara a derechos humanos, no solo porque no se garantizaba el derecho a la educación gratuita y obligatoria, sino también porque la impartida se enmarcaba en un modelo escolar autoritario y deshumanizado, con una estructura de poder escolar unipersonal, en la que el derecho a opinar del estudiante limitaba con el criterio del superior docente, y la organización estudiantil era negada como derecho y sancionada con la expulsión del plantel. De otro lado, vicios como la obligatoriedad de la profesión de la fe y el trato discriminatorio de la mujer, habían llevado a la escuela a un estado de sitio, que eliminaba en el niño el humanismo y cerraba los ojos frente a la tragedia nacional. Para Quintana (1996), las libertades individuales como la libertad de conciencia, de pensamiento, de opinión y de cultos, fundamento esencial del origen del sistema democrático moderno y el reconocimiento de la dignidad humana, eran negadas a diario en la comunidad educativa. Quintana (1998), aseveraba lo siguiente: 
La escuela no ha contado con instancias donde los protagonistas de la comunidad educativa puedan acudir a tratar sus conflictos, con las garantías propias del debido proceso, y sobre la base del respeto de sus derechos. Esto se debe básicamente a que el quehacer pedagógico, ha estado fundamentado en una estructura y funcionamiento que favorece la verticalidad y el autoritarismo en sus relaciones y decisiones. Tanto en los procesos pedagógicos como en la dinámica de la vida escolar el maestro ejerce un poder que tiende a convertirse en arbitrario (p. 69).

Investigaciones que se hicieron desde diferentes disciplinas de las ciencias sociales como la sociología, la historia, la antropología y especialmente desde la psicología, coincidieron que hasta en los aspectos más cotidianos de la escuela había rasgos de injusticia y abuso de autoridad de parte de los docentes. La campana, los timbres, los uniformes, las filas, la organización del salón de clases, el llamado a lista, hacían parte de las actividades rutinarias de la escuela que desde el enfoque de investigación que se viene exponiendo eran antidemocráticas. Sin embargo, las situaciones más graves eran, desde el punto de vista de los investigadores, los castigos físicos y psicológicos a que eran sometidos principalmente los niños en la escuela primaria. Estas expresiones de violencia de los maestros eran catalogadas en los estudios como las más graves, porque desde el punto de vista de los autores, se comprometía la salud mental de los adultos del futuro que siendo niños eran maltratados. Helda Martínez y Esperanza Martínez (1998) lo argumentaban de la siguiente manera:

Castigos como pellizcos, suspensión de recreos, coscorrones, son factores negativos en la práctica educativa. La agresión física y psicológica al menor se convierte en un círculo difícil de romper y terminar. La historia se repite una y otra vez de generación en generación. Los castigos, el maltrato físico, el desprecio, el acoso sexual, la exposición al ridículo, las humillaciones en público, son prácticas que hacen parte de la vida familiar y la vida escolar. Investigaciones llevadas cabo por educadores, psicólogos, médicos coinciden en establecer que los padres y los maestros que actúan así, lo hacen porque también fueron niños mal tratados (p. 36).

El gremio de los maestros también se expresó al respecto. La Revista Educación y Cultura, editada y publicada por FECODE, la Federación Colombiana de Maestros, en su editorial del $\mathrm{N}^{\circ} 16$, dedicado a la educación y los derechos humanos, señalaba lo siguiente: 
La violencia y con ella la violación de elementales derechos humanos y de la convivencia civilizada es una realidad que no sólo circunda la escuela, más aún la atraviesa, está presente en su realidad y cotidianidad. Los ejemplos de ello saltan a la vista: 70 educadores han sido asesinados en el último año, algunos ellos en sus propios sitios de trabajo, y 500 han recibido amenazas de muerte. En la ciudad de Medellín dos grupos de estudiantes de los colegios Pascual Bravo y el Liceo Antioqueño dirimen sus rivalidades juveniles y estudiantiles mediante la destrucción mutua de sus planteles escolares, ante la mirada impávida y la acción impotente de los profesores y los directivos. Los ejemplos se podían citar en extenso, pero estos dos resultan suficientes para conmover nuestra conciencia y entendimiento sobre lo que está pasando en la escuela y cómo ella es afectada por el clima de violencia que la circunda (FECODE, 1988, p. 2).

A diferencia de los "violentólogos" y otros investigadores, que consideraron que la verticalidad en las relaciones escolares recaía principalmente en el docente y su autoritarismo, desde la visión de FECODE la violencia en la escuela era la consecuencia de lo que pasaba al exterior de ésta, y los maestros eran también víctimas de la misma:

La educación colombiana por razones culturales y políticas que ameritan un análisis detallado, se ha caracterizado por su autoritarismo y verticalismo. En ella impera una disciplina exterior que requiere para su existencia de la omnipresencia contante de la autoridad. Lejos estamos de una disciplina que haya sido interiorizada por los individuos consciente y racionalmente, por el contrario los códigos y regímenes de sanciones, los reglamentos antidemocráticos, la disciplina de la sumisión, son la constante de la escuela y ello nos aleja de la posibilidad de una educación en libertad y en democracia (FECODE, 1988, p. 3).

Ante planteamientos como los hechos por algunos académicos y por representantes del Estado, entre ellos, el ministro de Educación, los maestros respondieron que si bien el gremio reconocía la necesidad de reflexionar sobre la escuela y la labor del maestro, y además expresaba su compromiso con la eliminación de situaciones de injusticia y arbitrariedades en el contexto escolar, rechazaban los señalamientos que se les hacían a los maestros como responsables de la crisis y de la violencia; argumentaban que "la escuela fue despojada de sus fines formativos, éticos y 
culturales, y la responsabilidad por sus resultados eran también de quienes la habían dirigido y orientado y quienes selavaban las manos responsabilizando principalmente a los docentes" (FECODE, 1988, p. 3). Los maestros argumentaron también que durante largo tiempo las clases dirigentes y sus sucesivos gobiernos colocaron en un plano secundario los propósitos culturales de la educación, concentrando todos sus esfuerzos en una acción instrumental en nombre de una pretendida modernización económica, que en el fondo no era más que su instrumentalización y racionalización, donde lo que importaba era la eficiencia en términos económicos.

A lo anterior hay que agregar que el aporte de los docentes al espíritu de la época no se quedó en la reflexión, el análisis e incluso el reclamo de los líderes sindicales de FECODE, ampliamente expresados en los Congresos del gremio y en la Revista Educación y Cultura. A quienes Cortés (2012) llama maestros de base, sacaron adelante investigaciones desde su experiencia en el diseño e implementación de proyectos pedagógicos de aula y otras metodologías que:

(...) mostraron la necesidad de generar una ruptura en la cultura escolar que pasara de la preocupación por la disciplina del orden a la formación de valores humanos y a la asunción de los conflictos morales, tanto en los estudiantes como en los maestros, como formas para alcanzar la ética pública (p. 438).

Estos grupos de maestros realizaron varios trabajos entre los que Cortés destaca: la convivencia y los valores para formar una ética pública del Colegio Rómulo Gallego, y Gocemos la escuela como una propuesta para desarrollar valores alternativos del Centro Educativo Distrital Antonio Nariño.

Las investigaciones reconocieron abiertamente el conflicto y con ello repensaron la noción de autoridad del maestro, ya no como guardián de la disciplina sino en una nueva función que le venían anunciando desde afuera: el maestro como guía, como acompañante del estudiante en esa misión de generar su propio proyecto de vida. Algunos priorizaron unos valores sobre otros en sus proyectos pedagógicos, yendo desde los más convencionales como la justicia hasta los más alternativos como la charla, el juego, la sensibilidad, la incertidumbre, el goce estético, el caos, el afecto, la diversidad y el conversatorio.

El equipo de maestros investigadores describió en detalle en su informe cada espacio, cada aspecto de la organización institucional, cada sujeto, cada rol, 
y recogió las opiniones y percepciones de cada uno, las analizó y las elaboró. Reconoció las causas de sus conflictos, los clasificó y tipificó, los ubicó en distintos escenarios y se ingenió los modos de afrontarlos. El tema de la convivencia escolar y el conflicto siguió mostrando la tensión entre libertad/ autoridad y entre participación/norma, lo que no pasó desapercibido a sus reflexiones. Su análisis de la relación entre norma-conflicto-convivencia, es elemental: la norma es un regulador de la convivencia. Esta es una construcción de los sujetos; por lo tanto los pactos, acuerdos y compromisos para convivir son el punto de referencia (Cortés, 2012, p. 440).

Las reflexiones que hicieron sobre la convivencia escolar, llevaron a estos grupos de maestros a hacer sus propias definiciones, hecho que les dio la condición de maestro investigador/innovador; en los proyectos de aula desarrollados por los profesores la dimensión política de la moral se pone de presente como alternativa fundamental en la reconstrucción de lo social y lo público (Cortés, 2012). Estos proyectos de formación para una ética pública, civil o ciudadana en la escuela proponían que los sujetos pudieron tomar sus propias decisiones en todos los órdenes: morales, afectivas y políticas.

\subsection{La democratización de la vida escolar en Colombia}

\subsubsection{La educación cívica: antecedente de la educación para la democracia}

Una revisión histórica a la relación democracia educación nos remite al pensamiento de Dewey, desde su punto de vista, en el contexto educativo es observablela realización de una forma de vida social en la que los intereses se penetran recíprocamente y donde el progreso o reajuste merece una importante consideración, hacia una sociedad democrática más interesada que otras en organizar una educación deliberada y sistemática. Esa educación más deliberada, sistemática, más democrática para Dewey (1995) depende del reconocimiento de los intereses mutuos como un factor del control social y de un cambio en los hábitos sociales.

Pese a las diferencias sobre las causas que habían producido relaciones verticales, injusticias y falta de igualdad entre los actores educativos, el Estado, los maestros y los académicos coincidían en la necesidad de implementar una cultura democrática en la escuela. Hay que decir, sin embargo, que mucho de lo que se enunciaba como formación para la democracia no era nuevo, ya que había estado incluido en el currículo como educación cívica; si bien emergía una nueva terminología que incluía conceptos como la educación en y para la democracia y la formación 
ciudadana a finales de los años 80 y principios de los 90; anteriormente había sido común hablar de la educación cívica para nombrar los temas relacionados con la formación política y la orientación del comportamiento de los estudiantes.

Gráfica 4. Democratización de la vida escolar

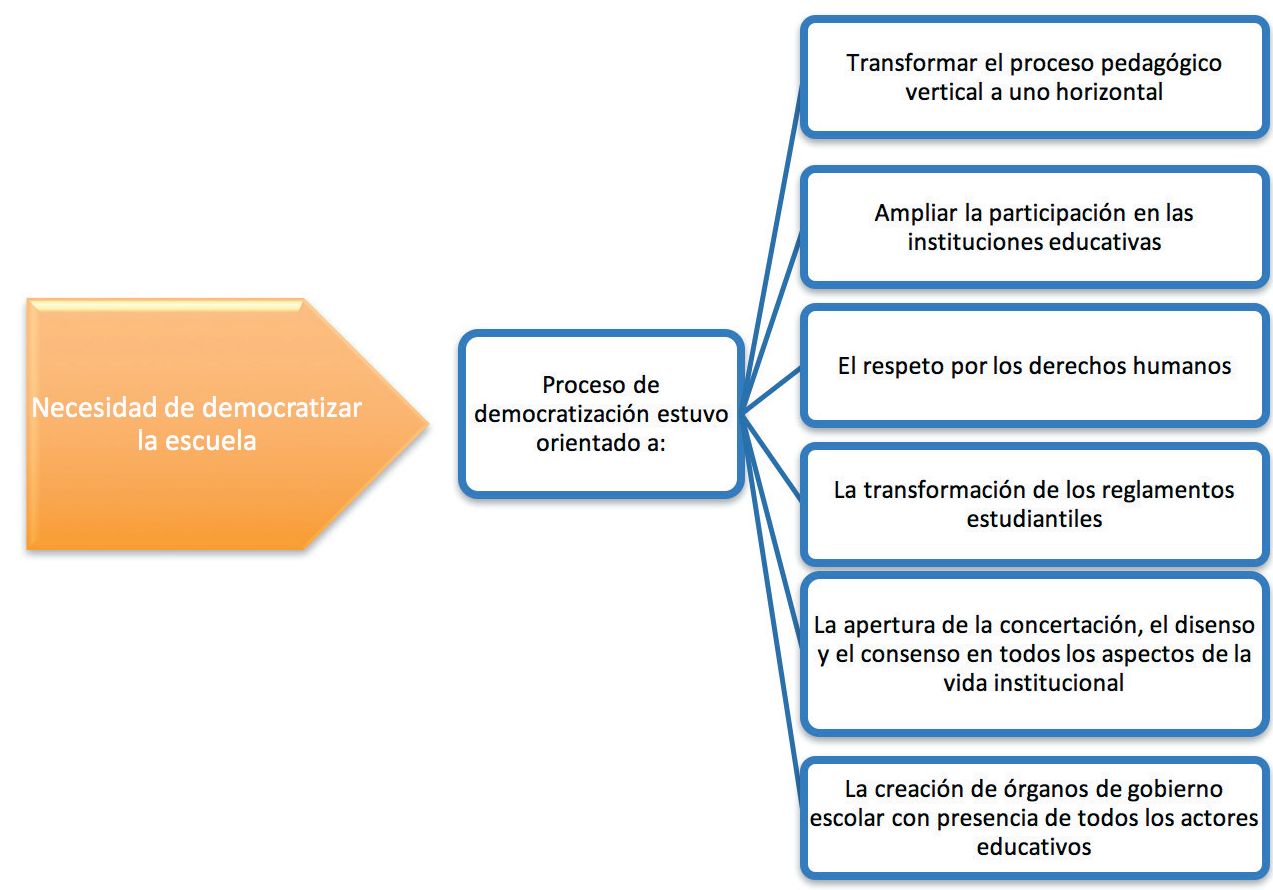

Desde finales del siglo XIX y principios del siglo XX, la cívica en Colombia estuvo fuertemente ligada a la enseñanza de la urbanidad, el culto a los símbolos patrios y a la memorización de las características del régimen político colombiano (MEN, 1998, citado por Peláez y Márquez, 2006). Según Melo (2002), desde las primeras décadas del siglo XX se empezó a promocionar la enseñanza de la historia como vehículo para la educación en ciudadanía; se divulgaron textos de cívica y se empezó a promover la idea de un gobierno escolar dentro del cual se debía elegir a un presidente estudiantil. Lo que evidenció Melo, es que desde la primera mitad del siglo XX, se registraron intentos para adoptar metodologías de enseñanza que incluyeran la puesta en práctica de gobiernos escolares y en general de metodologías más activas. 
A mediados de siglo los avances en la educación cívica se estancaron porque el régimen dictatorial de Rojas Pinilla no tenía interés en la difusión valores democráticos o formas de participación ciudadana. Reemplazó la educación cívica por la cátedra bolivariana y la cátedra de la hispanidad.

Después de la dictadura, y pese a la irrupción de este hecho en la vida nacional, los gobiernos siguientes no realizaron mayores esfuerzos para promover una cultura democrática más allá de las tradicionales clases de cívica (Peláez y Márquez, 2006). De acuerdo con Rodríguez (1998), en las décadas de los años sesenta, setenta y principios de los ochenta, los planes de estudio hacían énfasis en la memorización de las características, funciones y mecanismos de las instituciones políticas, sin ninguna contextualización con las realidades económicas y sociales que rodean dichas instituciones:

Sólo hasta 1984 volvería a tomar fuerza la idea de la educación para la democracia, debido principalmente al programa de renovación curricular adelantado por el gobierno; mediante este programa se intentaron reformular los marcos conceptuales para las diferentes áreas pedagógicas, reestructurar los planes de estudio y transformar la relación entre la escuela y la comunidad (p. 35).

La renovación curricular de la segunda mitad de los años ochenta, la situación de violencia, la crisis institucional del país, el clima de reforma constitucional y la proclamación de la Ley General de Educación en 1994, son los antecedentes de la política de democratización de la escuela colombiana. El reto era tan grande que desde el principio hubo dudas sobre los logros que se podrían alcanzar. Aguilar y Betancourt (1999), sugerían que los límites que el orden, la estructura y la rutina escolar tenían, suponían grandes interrogantes a la posibilidad de democratizar el entorno escolar. Pese a lo anterior, se dio paso al surgimiento de importantes propuestas y programas de educación para la democracia, los derechos humanos y la paz, tendientes a legitimar el orden institucional y a favorecer las prácticas de convivencia pacífica en las escuelas.

\subsubsection{Los objetivos y las metas de la democratización de la escuela}

La educación colombiana se enfrentaba a un proceso democratizador de la escuela, orientado a transformar el proceso pedagógico vertical existente. Se buscaba hacerlo horizontal, participativo e integral, en el entendido de constituir el gobierno escolar en cada institución educativa, y que las Juntas de educación municipales 
y departamentales, permitieran construir desde estos espacios de participación una cultura democrática, participativa, de tolerancia y convivencia (Montes de Oca, 1994, p. 51). Crear un ambiente democrático se convirtió en un indicador de gestión de los establecimientos educativos; los decisores y toda la comunidad escolar debían crear una cultura y un clima organizacional en la escuela en donde se promovieran el trabajo en equipo, la cooperación, la participación, la democracia, la interdisciplinariedad, el pluralismo, el respeto, la convivencia y las relaciones interpersonales sanas, como valores para generar una gestión democrática como laboratorio en donde se experimenten las macro - conductas sociales que anhela la comunidad (Arboleda, 1994, p. 31).

Los objetivos de la política gubernamental quedaron explicitados en varias publicaciones del Ministerio de Educación Nacional. El Plan Decenal de Educación 1996 - 2005 en su capítulo II, "Propósitos generales", contemplaba que "la educación debía contribuir en forma eficaz y sistemática a la profundización de la democracia, la participación ciudadana, la construcción de una cultura de la convivencia y respeto de los derechos humanos y a la conquista de la paz" (p. 6). El proyecto de educación para la democracia reglamentado a través de la resolución 1600 de 1994, también publicada por el Ministerio de Educación, definió entre sus finalidades las siguientes:

1. El desarrollo de actitudes, habilidades y conocimientos necesarios para la participación responsable como ciudadanos en una sociedad democrática.

2. La comprensión, valoración y práctica de la Constitución Política, de la estructura y fines del estado, de la función de la administración pública y de conceptos tales como libertad, democracia, responsabilidad, ética, orden, autoridad, gobierno, solidaridad, tolerancia y respeto por la opinión ajena, los derechos humanos, etnias y las culturas, de manera que se asuman conductas cívicas dentro de la propia comunidad y en las demás esferas de la vida política y social.

3. El reconocimiento, aceptación y respeto de los derechos propios y de los demás para el logro de una sociedad justa y pacífica.

4. La práctica y el conocimiento de los mecanismos de participación política y ciudadana que formen a la persona para asumir un papel activo y democrático en las decisiones nacionales, regionales y locales que afecten a su comunidad. 
5. El manejo de los conflictos como algo inherente a las relaciones interpersonales e intergrupales y su resolución sin acudir a la violencia, incorporando la equidad, la negociación y la transacción en la solución de los mismos.

7. La adopción de formas de diálogo, deliberación, controversia, concertación, consenso y compromiso frente a las relaciones interpersonales, sociales y políticas;

8. El desarrollo de la propia autonomía, de la conciencia personal y de las actitudes críticas y creativas.

9. La formación en una ética del trabajo, de las actividades de tiempo libre y de las relaciones con el medio físico natural y creado.

10. El fortalecimiento de la autonomía escolar y el reconocimiento de la historia, la identidad y las culturas nacional, regional y local (MEN, 1994, p. 1).

Los propósitos generales del plan decenal de educación y las finalidades del proyecto de educación para la democracia, pasaban por la redefinición de las relaciones de poder que impiden al tránsito hacia formas de concertación, de disenso y de consenso y por el reconocimiento recíproco de los derechos fundamentales de los integrantes de la comunidad educativa; es decir, la libertad en todas sus manifestaciones; la libertad como expresión de conciencia, como libre desarrollo de la personalidad y como autonomía moral (Quintana, 1996). La democracia en la escuela se construía justamente a partir del reconocimiento pleno de los derechos y de la adquisición de estatus de protagonistas de la dinámica educativa de padres de familia y estudiantes. Para ello, era necesaria toda una pedagogía de los derechos humanos y los principios democráticos de tal manera que se convierta en el paradigma ético de la convivencia en la escuela (Quintana, 1996).

La necesidad de dar voz y hacer parte importante de la escuela a los padres, a los estudiantes y a sus comunidades no era decisión tomada exclusivamente en el sistema educativo colombiano, sino que era parte de una tendencia internacional y regional. La Declaración de Cochabamba de 2001, producto de una reunión para hacer seguimiento a los avances de las seis metas de Educación para todos que se habían fijado en el Foro Mundial de Dakar del 2000, tuvo entre sus recomendaciones en política educativa para el inicio del siglo XXI la siguiente: 
Siendo la educación un derecho y un deber de cada persona compartido por la sociedad, es necesario crear mecanismos adecuados y flexibles que aseguren una sostenida participación de múltiples actores y se incentiven prácticas intersectoriales en el campo de la educación. Los mecanismos de integración deben estar referidos a los distintos ámbitos del quehacer educativo, comenzando con la familia, el aula y la institución escolar y priorizando su vinculación con el desarrollo local. Es condición necesaria para aumentar la participación de la comunidad en la educación que el Estado asuma un efectivo liderazgo estimulando la participación de la sociedad en el diseño, la ejecución y la evaluación del impacto de las políticas educativas (p. 7).

En el número 16 de revista Educación y Cultura, dedicado exclusivamente a la educación y los derechos humanos, Sáenz (1988), decía que ante la situación del país atravesada por una violencia generalizada, la violación permanente de los derechos humanos y una profunda crisis de valores morales que abarcaba todos los estamentos sociales, representaba para el movimiento pedagógico una llamada a la reflexión sobre el papel formador de la escuela; por su parte, Cubides (2000), concluyó que la política, la participación y la representación debían favorecer cambios en las culturas institucionales; según el investigador, la modificación de ritmos, el papel de los actores, los hábitos institucionales y los procesos comunicativos debían ser el foco principal de las transformaciones educativas. El sentir generalizado era que en el ámbito de un proyecto de educación para la democracia, era fundamental la generación de procesos en los que se integrara el conjunto de la comunidad educativa y especialmente la intervención de los alumnos y padres de familia (Vargas, 1996, p. 12); estos miembros de las instituciones debían ser considerados como actores, es decir, participantes activos en la socialización de las nuevas generaciones.

La apertura de la escuela a las comunidades y a la actuación dinámica de padres y estudiantes, requería de un cambio radical en las actitudes y comportamiento de los educadores. Como se ha mencionado, éstos habían sido responsabilizados de las principales acciones antidemocráticas en el contexto escolar. En el $2^{\circ}$ Congreso Pedagógico Nacional, la misma Confederación Nacional de Centros Docentes, CONACED, expresaba:

Es la oportunidad para que el maestro repiense su papel, se ubique en el aula como una persona, reconociendo que su relación con la comunidad no es a partir del conocimiento. Tampoco lo es de la autoridad, menos desde lo disciplinario, éstos son apenas mediadores, pero no los ejes de la labor docente. El maestro es dinamizador de procesos de aprendizajes, de socialización, de creatividad y en general de todo aquello que significa la humanidad, por ello 
el enseñar debe dejar de ser una labor entorno a los contenidos y la transmisión de los mismos, la labor del educador es propiciar espacios, crear oportunidades y establecer pretextos para que nuestros discentes tiendan puentes, creen acciones, hagan textos, y en fin se afiancen como personas (Murillo, 1994, p. 55).

Lo que se sugería era un cambio radical en el papel del maestro; ahora debía ser dinamizador de los procesos de aprendizaje, uno más en la institución, falible, no como quien tiene la verdad revelada frente a los estudiantes y los padres de familia; "un maestro debía ser una gran persona, un estudioso, un investigador, un amigo, un compañero de los estudiantes, de los padres, y, por supuesto, de los mismos docentes" (Nieves, 1994, p. 60). Se proponía también que el maestro fuera una especie de filósofo moral que buscara entender el pensamiento del niño y la manera como éste percibe el significado moral de las acciones del maestro:

el maestro, anclado su saber pedagógico en una elevada práctica moral y en una profunda reflexión ética que cuestione los juicios morales ingenuos del alumno, que le presente dilemas morales de la vida cotidiana, y le aleccione, cuestione y discuta con el alumno, creándole conflictos y dudas morales (Sáenz, 1988, p. 19).

Este nuevo docente suponía un compromiso de los docentes traducido en una actitud positiva hacia el cambio, un docente cada día más conocedor de las limitaciones estructurales de la labor educativa, inquieta, creativa y responsable de su papel socializador.

El requerimiento a otro maestro se acompañaba de una nueva concepción de estudiante, de manera que éstos percibieran con claridad qué derechos y qué deberes tenían, que eran ahora el centro del proceso educativo y debían participar activamente en su formación. Para ello era necesario producir transformaciones, especialmente en el método, y abandonar las clases esquemáticas, rígidas y monótonas y el ejercicio exagerado de la autoridad del maestro sobre el estudiante al impedirle una participación más activa y espontánea. Esto requería como aspecto prioritario involucrar en el proceso educativo los intereses, necesidades, manifestaciones e iniciativas propias de los niños, niñas y jóvenes estudiantes, porque lo que predominaba era los intereses y metas de los adultos. Ello requería llenar de contenidos y vivencias cotidianas todos y cada uno de los derechos de los estudiantes, en un diálogo intergeneracional que garantizara el interés superior de la infancia y la protección integral de la misma (Aguilar y Betancourt, 1999, pp.14-15). 


\subsubsection{Ejes del proyecto de democratización de la escuela colombiana}

\section{La educación para la ciudadanía}

La cercanía o lejanía entre la escuela y la infancia hace parte de una reflexión como la que plantemos en el libro. Desde la perspectiva de Southwell (2015), la escuela tuvo mucho que ver con la delimitación de la infancia, tanto por la difusión de un discurso psicológico que estableció de manera taxativa qué debía esperarse de los niños, como por la expansión de una idea de minoridad-incompletud-inmadurez que colocó a la infancia en un lugar subordinado, cuya voz y perspectivas no debían tenerse en cuenta.

Para Southwell la escuela fue determinante en la producción de una idea de infancia correcta y aceptable en términos morales y políticos, era su papel aportar en la formación de un buen niño o niña. Esta visión sin duda justificaba la importancia de la escuela y la centralidad de su papel. Pero ante la realidad de hoy en la cual los niños y jóvenes se comportan como sujetos con igual capacidad de decidir, de consumir y de ser objeto de discursos mediáticos como los adultos.

La escuela tiene el imperativo de poner en funcionamiento decisiones que pongan en acto los derechos y a hacerlos cotidianos, operando en las situaciones de conflicto, estableciendo acuerdos y mostrando las implicancias de las faltas de cuidado sobre los y las otro/as y sobre sí mismos. En esa búsqueda, la enseñanza de la reciprocidad y la mutua implicancia de nuestros actos pone a nuestras instituciones algunos pasos adelante para la vivencia de lo humano (Southwell, 2015, p.4).

Uno de los componentes centrales de reforma educativa encaminada a democratizar la escuela colombiana fue el de la educación para la ciudadanía. Este se desarrollaría de forma paralela y complementaria al componente de democratización dela escuela, porque desde el punto de vista de quienes asesoraban y diseñaban la política pública educativa, los actores educativos no parecían involucrados en la formación ciudadana de los estudiantes. 
Gráfica 5. Educación para la ciudadanía
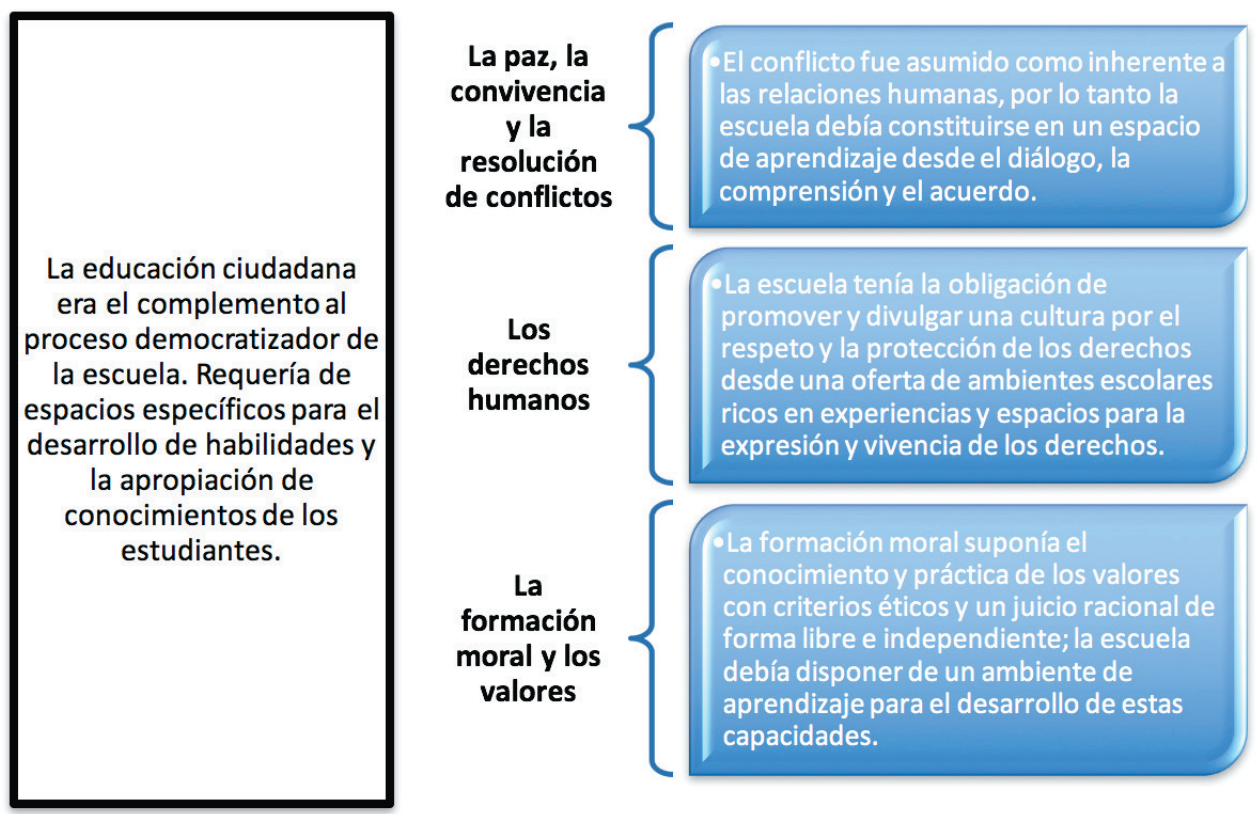

La formación en ciudadanía requería de espacios específicos donde se desarrollaran habilidades y competencias necesarias. La propuesta incluyó principalmente tres aspectos: la paz, la convivencia y la resolución de conflictos. Los derechos humanos, la formación moral y los valores no se concebían de manera aislada, sino que por el contrario, había entre ellos tan fuertes conexiones que hicieron que en algunos de los programas que se implementaron en las instituciones se presentaran mezclados o como una sola cosa.

En cuanto a la paz, la convivencia y la resolución de conflictos, hay que decir que éste gran ítem fue uno de los componentes en los que se hizo más énfasis, tal vez porque gran parte de las acciones estuvieron encaminadas a superar la inestabilidad política que se vivía en el país, generada por la violencia de los diferentes grupos ilegales en las décadas del 80 y del 90, y la desinstitucionalización y corrupción de las Fuerzas Militares, las cuales también cometieron actos de violencia de derechos humanos y crímenes de Estado (Delgado et al., 2005). El conflicto fue visto como una situación de oposición de intereses entre dos o más personas. Desde esta posición se encontraron dos formas de abordarlo: en la primera, el conflicto fue asumido desde concepciones rígidas que funcionan como certezas a partir de las cuales es transmitido. En la segunda perspectiva predomina el ir y venir de opiniones, 
criterios, emociones y sentimientos, lo que permite la reflexión y transformación de los conflictos, generándose seres más autónomos, libres y creativos (Delgado et al., 2005, p. 107).

El objetivo era convertir la educación en un escenario en donde transcurrieran el debate y la reflexión sobre las disyuntivas inherentes a cualquier sociedad, en aras de formar una cultura democrática fundamentada en el reconocimiento de la diferencia, la inclusión de la igualdad de oportunidades para la participación y desde allí, transformar los estilos de socialización autoritarios y rígidos que reproducen formas simbólicas de violencia en las relaciones cotidianas. Era importante asumir el conflicto (como inherente a las relaciones humanas, por lo tanto, la escuela debía constituirse en un espacio de aprendizaje en el diálogo, la comprensión y el acuerdo; Delgado et al., 2005). Por lo anterior, se requería enseñar a los estudiantes estrategias de negociación para el establecimiento de acuerdos, así como formarlos en el compromiso de cumplirlos; la formación de los estudiantes se orientaría entonces a la adquisición de habilidades y capacidades de acción en el mundo en que viven, y a la creación de espacios de acción donde se ejerciten las habilidades que se desea desarrollar.

\section{La participación de todos los estamentos educativos}

Un papel fundamental tuvo en la democratización de la vida escolar el tema de la participación; la visión de la reforma educativa presupuestaba que los padres de familia, la iglesia, los partidos políticos y las organizaciones gubernamentales y no gubernamentales, además de querer saber qué sucedía en la educación, deseaban participar activamente en las decisiones que la afectaban. Aguilar y Betancourt (1999), subrayan la importancia de este aspecto afirmando que la democracia y la convivencia en la escuela se hacen posibles a través de procesos prácticos de participación, deliberación pública, asunción de responsabilidades políticas y ejercicio de poderes efectivos.

El componente de la participación en el proyecto democratizador se cristalizó principalmente en la creación de instancias de participación y deliberación de todos los sectores de la comunidad educativa: consejo directivo, consejo académico, consejo de padres de familia, consejo de estudiantes, personería estudiantil; estas instancias de participación tendrían, entre otras funciones, la del diseño y modificación del componente pedagógico y curricular, la adopción y verificación del reglamento escolar y la organización de actividades académicas, sociales, deportivas, culturales y artísticas en las instituciones, además de voz y voto en la elaboración y ejecución del presupuesto y en la imposición de sanciones disciplinarias a los estudiantes. 
Así, la participación de la comunidad educativa en las decisiones de su institución permitiría el desarrollo de una pedagogía para la democracia; la elección anual de órganos de participación ayudaría a un entrenamiento de la comunidad en los aspectos básicos de la dinámica electoral: la campaña de los candidatos, la elección de los jurados, el sufragio y la realización de los escrutinios, tendrían de este modo un valor pedagógico, en la medida en que podrían convertirse en mecanismos que propiciaban el aprendizaje y la adopción de nuevas actitudes y comportamientos en una convivencia democrática como la tolerancia y el respeto por el otro (Quintana, 1996). Hacer parte de las instancias de participación en los establecimientos educativos suponía un doble beneficio; el fortalecimiento del espíritu de participación de los padres de familia y profesores, ciudadanos en ejercicio pleno de sus derechos civiles y políticos y el entrenamiento en prácticas políticas de los estudiantes como ciudadanos del futuro, contribuirían a reducir los altos índices de abstencionismo electoral y las prácticas clientelistas que le estaban restando legitimidad a la democracia.

La presencia de los estudiantes, de los padres de familia y de otras personas en el contexto social de la institución educativa suponía mucha importancia en el proceso democratizador de la escuela porque contribuía a equilibrar el manejo del poder, hasta ahora hegemonizado por docentes y directivos y porque habría nuevos espacios de participación para los estudiantes, contribuyendo al fortalecimiento de su autonomía.

\section{La promoción de los derechos}

El componente de los derechos también fue muy importante en las estrategias que se propusieron en la educación para la ciudadanía; en diversos ámbitos se resaltaba el papel central que debía jugar la escuela en la promoción y divulgación de una cultura del respeto y la protección de los derechos humanos (Pinilla y Torres, 2006). Desde las visión de los programas educativos, los derechos no tenían que ver solo con una expresión formal en los reglamentos escolares, sino también con la oferta de ambientes escolares ricos en experiencias y espacios para la expresión y vivencia de los derechos, que no podían ser negados en aras de los deberes, sino que requerían ser negociados a partir de los intereses de los estudiantes y la oferta pedagógica de la institución (Aguilar y Betancourt, 1999, p. 173).

Fueron innumerables las campañas promovidas desde el Ministerio de Educación que reconocían los derechos como un asunto de vital importancia que competía a la educación. La escuela estaba en mora de incorporar los derechos en los contenidos y 
en las actividades escolares; en la editorial de la Revista Educación y Cultura $\mathrm{N}^{\circ} 16$, se señalaba que los derechos tenían que ver con la esencia de la función formadora y socializadora de nuestro sistema educativo y enfatizaba en la importancia de llevarlos a la escuela con apreciaciones como la siguiente:

Los derechos humanos tienen una dimensión cultural y pedagógica. Desgraciadamente nuestro sistema educativo no tiene una tradición en este campo, es mucho lo que hay que hacer para formar una cultura democrática anclada en el respeto y la defensa de los derechos, un verdadero desafío para el magisterio y la educación colombiana (FECODE, 1998, p. 2).

Las estrategias pedagógicas que se propusieron desde el gremio de los maestros, el Ministerio de Educación, ONGS ligadas al campo educativo y algunos centros de investigación como el IDEP y el Instituto Luis Carlos Galán, coincidían en que la temática de los derechos humanos adquiere legitimidad cuando se le confiere poder en el currículo, cuando son aprendizajes evaluables, cuando se le destina un tiempo, cuando hace parte de la cotidianidad de la escuela. Según Delpiano y Madnenzo (1998), la temática de los derechos se expresa en la cultura propia de la escuela, en las interacciones que se establecen entre profesores y alumnos y de éstos entre sí, en las metodologías de enseñanza que se alejan de los esquemas autoritarios en el sistema organizativo de la escuela.

Estos mismos autores destacan que los derechos no deben ser trabajados como un contenido que se encuentra afuera y que se incorpora adentro. Para ellos, los establecimientos educativos debían hacer mucho más que eso; lo que sugerían era:

[...] un proceso de reconstrucción de un saber, de un pensar, un sentir y actuar en que las subjetividades y los significados propios que le otorgan los actores educativos a su existencia van configurando el conocimiento y la experiencia de los derechos humanos (Delpiano y Madnenzo, 1998, p. 8).

La nueva concepción de enseñanza de los derechos suponía la superación de actividades como la lectura de la Declaración de los Derechos del Niño y las exposiciones, carteleras o resúmenes sobre lo que los estudiantes entendían de X o Y artículos. Si bien estas actividades no eran despreciables, a lo que se debía apuntar era a actividades que promovieran los derechos como práctica dentro del quehacer educativo, para lo que era necesario que los docentes fueran muy creativos en la planeación de las actividades e incluyeran el tema de los derechos en las temáticas, no de una, sino de todas las asignaturas, así como de otros eventos culturales, deportivos y académicos. Los derechos debían ser contenidos transversales en todas las asignaturas y los proyectos pedagógicos obligatorios (Delpiano y Madnenzo, 
1998). El criterio de trabajo que se planteaba era el conocimiento, difusión y práctica de los derechos humanos en el aula, la escuela y la comunidad inmediata, se proponía un trabajo masivo de socialización de derechos, tanto a nivel educativo como a nivel de la opinión pública, con el fin de lograr que su conocimiento e interiorización formaran parte natural del pensamiento y la actuación cotidianos.

\section{La formación moral y los valores}

Otro componente importante de la educación para la democracia fue el de la formación moral y los valores. Este componente tenía su importancia porque muchas voces opinaban que la crisis de la sociedad y de la violencia se debía a la falta o la decadencia de valores familiares y comunitarios. La formación moral suponía el conocimiento y práctica de los valores universales con criterios éticos y un juicio racional libre e independiente, y la escuela debía disponer de un ambiente de aprendizaje para el desarrollo de estas capacidades. Según Rincón et al. (2001), la formación ciudadana como problema de conocimiento no era motivo de reflexión ni estudio en la escuela: de allí que fuera un problema que estaba atravesado en la cotidianidad por conflictos, actitudes y comportamientos en los que estaba implicada la moral.

Delgado et al. (2005), mostraron que en la tradición escolar la ruta de la educación moral se inició con las concepciones doctrinales y eclesiales, incorporó gradualmente las concepciones cívicas y universales y desde allí se avanzó hacia la asociación explicita con los derechos humanos y la justicia como equidad. Desde la perspectiva de Cortés (2012), en los años 90:

[...] educar moralmente en pos de la responsabilización de la vida, requería algo más que del clero religioso, o de volver a Carreño y a Astete (a la urbanidad, la cívica y el catecismo); eran otras las maneras requeridas para generar más confianza en que la apuesta por construir un proyecto ético-cívico estuviera alejada de un dogmatismo religioso (p. 428).

El soporte para ello era mostrar una fundamentación de carácter científico como parte de la intención de secularización. Cortés subrayó la emergencia de nuevas tecnologías de formación de la subjetividad moral, que ahora involucraban la emocionalidad, las valoraciones culturales, las autorregulaciones y la asunción del conflicto personal y colectivo como escenario de un proyecto de vida. De la misma manera, en el campo de la educación moral, destacó la presencia de discusiones kantianas y aristotélicas, pero principalmente a Piaget y Kohlberg como los autores 
que marcarían la pauta en las nuevas estrategias de moralización de los escolares. Delgado et al. (2005), anotaron que en la definición de los marcos de justificación moral se apreciaba una educación orientada hacia valores como la solidaridad, la libertad, la honestidad, la equidad, la justicia, la igualdad y el diálogo, y en la complementariedad que debía existir entre estos valores en la construcción de una ética cívica. Teniendo como marco herramientas de los trabajos de Yáñez y Fonseca en el 2003 y Mesa en el 2004, Cortés (2012), identificó tres grupos de perspectivas teóricas desde las cuales se propusieron estrategias pedagógicas para el desarrollo del juicio moral y los valores, según la concepción ética que asumen y que ponen de manifiesto la tensión entre individuo y comunidad y la forma como se entiende el desarrollo del individuo.

Gráfica 6. Perspectivas teóricas y propuestas pedagógicas para el desarrollo del juicio moral
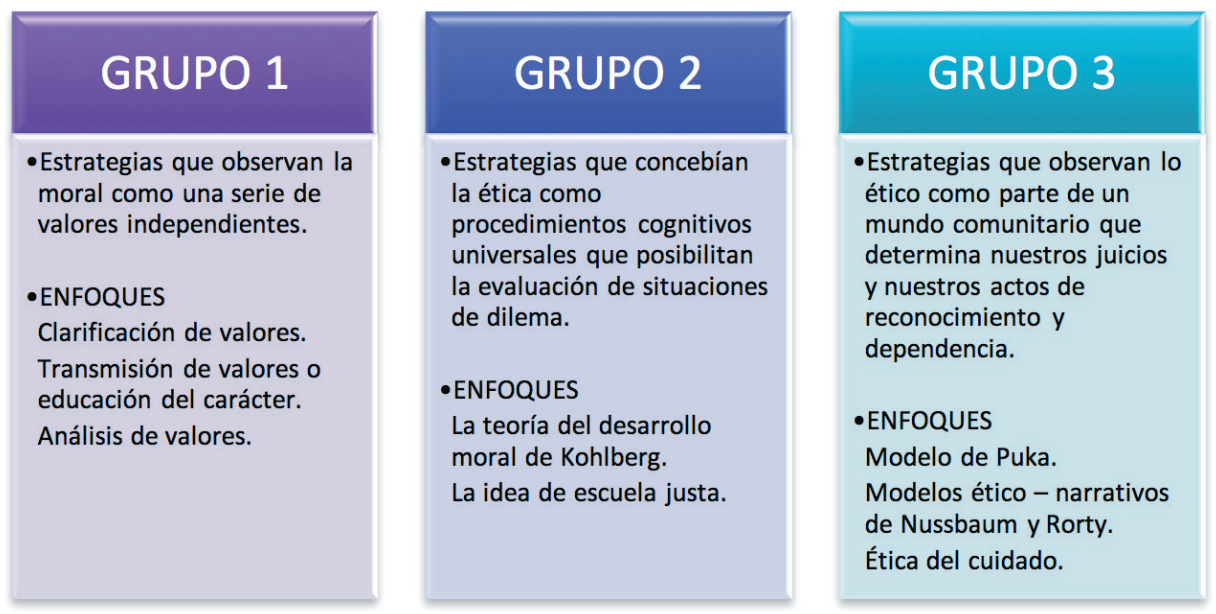

Fuente: Cortés (2012), Citando a Yánez y Fonseca (2003), y a Mesa (2004). El cuadro fue elaborado por la autora de esta investigación

Yáñez y Fonseca en el (2003) y Mesa en el (2004), citados por Cortés (2012), evidenciaron que los enfoques del primer grupo buscaron facultar a los estudiantes para ser los únicos responsables de sus valores, los jueces últimos de aquellos valores que podían orientar su vida, inculcar valores que se consideran moralmente correctos dentro del grupo social, y moldear positivamente el carácter; desarrollar en los estudiantes capacidades intelectuales que les permitieran analizar de 
manera lógica los problemas desde distintas perspectivas. En los enfoques del segundo grupo la meta era estimular el desarrollo natural del razonamiento y las habilidades morales de los estudiantes hacia la justicia; en este grupo también se crearon estrategias para la educación moral que se centraban en dar importancia a los procesos comunicativos subjetivos, con una metodología de debate intergrupal sobre situaciones que se ofrecían como problemas morales.

En las estrategias de enseñanza del tercer grupo, se asumía que los juicios morales serían la expresión de una tradición y la pertenencia a dicha tradición posibilitaría reconocer aquellos a quienes consideramos semejantes e impulsaría a defender cierto tipo de símbolos, personajes, narraciones o instituciones con los que un individuo se identifica y sobre los que construye un sentido de pertenencia e identidad. Las estrategias pedagógicas de este grupo contemplaban el uso de la literatura y otras formas de arte para desarrollar juicios y sentidos morales, y la construcción de un currículo escolar en el que los estudiantes aprendieran a crear y mantener relaciones de cuidado con los demás, con las plantas y con los animales.

\subsection{Reformas en el currículo y en la organización social de la escuela}

Como se ha mostrado, si bien es cierto que el proyecto de democratización de la escuela y la educación en ciudadanía se puso en marcha en la década del 90, algunas de las acciones que se realizaron tenían antecedentes en décadas anteriores. 
Gráfica 7. Reformas en el currículo y en la organización social de la escuela

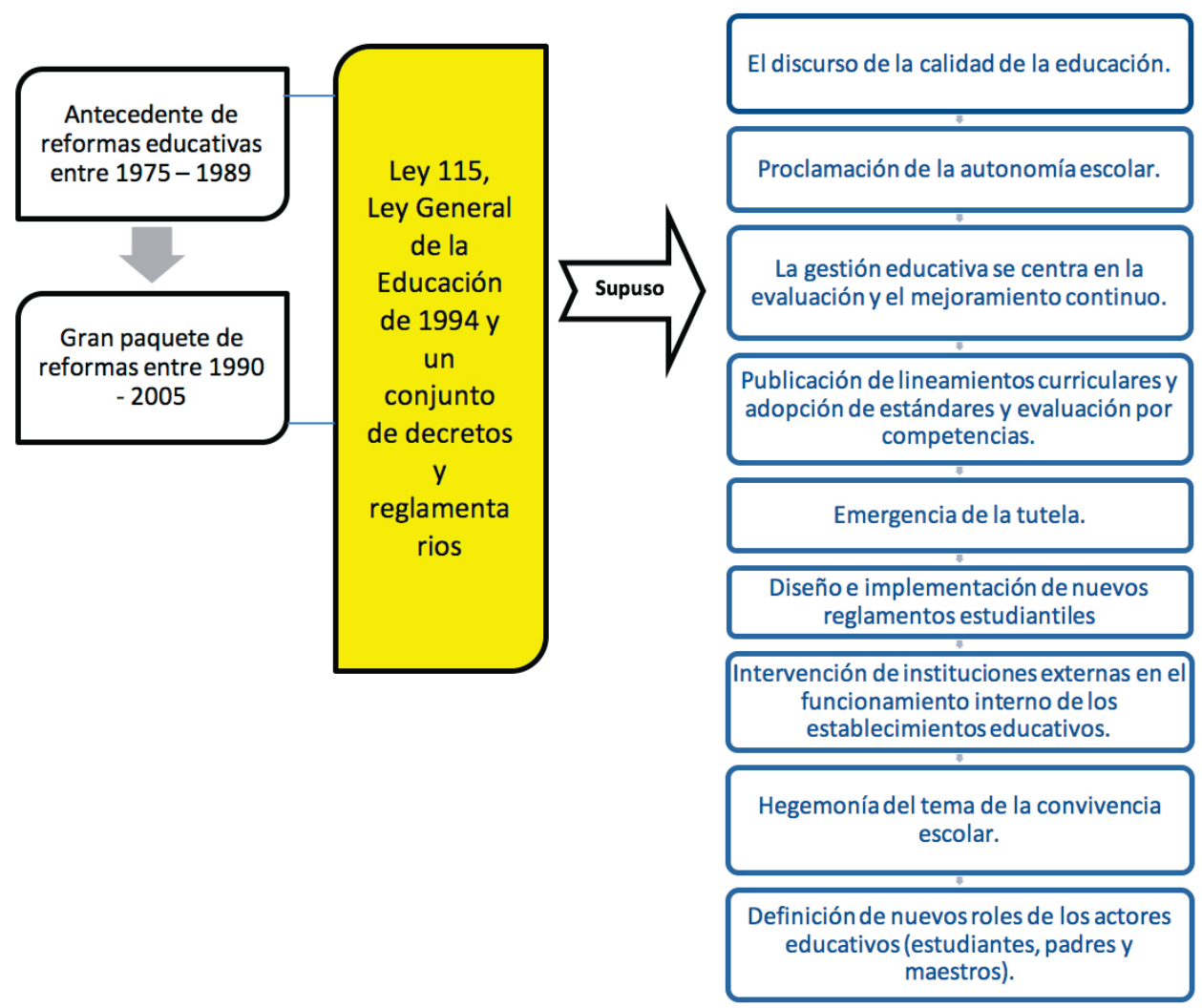

Fuente: Ministerio de Educación Nacional, 1994

En lo que tiene que ver con las reformas curriculares, en 1978 fue promulgado el decreto 1419 para señalar las normas y orientaciones básicas para la administración curricular en los niveles de educación pre-escolar, primaria, secundaria y media vocacional. Entre los fines del sistema educativo se establecieron contribuir al desarrollo equilibrado del individuo y de la sociedad sobre la base del respeto por la vida y por los derechos humanos; fomentar el estudio de los propios valores y el conocimiento y respeto de los valores característicos de los diferentes grupos humanos y formar una persona moral y cívicamente responsable. Este decreto incluía un aspecto sobre el cual girarían las reformas educativas desde los años 90 hasta hoy: la ubicación de los estudiantes en el centro del proceso educativo, para que se desarrollaran armónica e integralmente como personas y como miembros de la comunidad. 
Desde la década del 80 (y con mayor vigor en la del 90), se vienen impulsando en Iberoamérica reformas legales de los sistemas educativos, que por su recurrencia se han convertido en un signo más de lo que está pasando. Los argumentos que las justifican, sobre todo en América Latina, tienen que ver con su supuesto fracaso en las políticas que se venían desarrollando desde la década del 50. Se habla entonces de un giro radical en la manera de organizar el sistema, con el propósito de responder a los retos de cobertura y calidad, en un mundo que, tal como lo reconocen los discursos introductorios a las reformas, se está globalizado y exige mayores niveles de competitividad (Álvarez, 2001, p. 10).

En 1980, y con el propósito de inculcar en la juventud colombiana los ideales del Libertador Simón Bolívar, se estableció la Cátedra Bolivariana para la educación secundaria. Esta cátedra era obligatoria en los establecimientos de educación secundaria oficiales y no oficiales en el grado noveno, con una intensidad semanal de una hora en el área de ciencias sociales.

Con el decreto 0239 de 1983 se adoptaron nuevas cátedras y jornadas escolares en la educación primaria y secundaria, se estableció como obligatoria la asignatura de Educación para la democracia, la paz y la vida social, en todos los grados de educación pre-escolar y básica primaria con intensidad de una hora semanal. A partir de 1984 el decreto también regiría para los niveles de educación básica secundaria; los contenidos de la cátedra se asignaron al área de ciencias sociales, con una hora semanal de intensificación. La inclusión de la cátedra de la Educación para la democracia, la paz y vida social tenía como objetivo inculcar la devoción por la libertad, la participación democrática, la equidad y la justicia social, el respeto por la autoridad y el orden jurídico y la práctica de los deberes y derechos de los ciudadanos.

En 1984 el Ministerio de Educación estableció el plan de estudios para la educación pre- escolar, básica primaria, secundaria y media vocacional de la formación formal mediante el decreto 1002; entre sus objetivos estaban identificar y valorar los factores que influyen en el desarrollo social, cultural, económico y político del país y participar crítica y creativamente en la solución de los problemas y el desarrollo de la comunidad, teniendo en cuenta los principios democráticos de la nacionalidad colombiana. Las reformas reseñadas indican que desde finales de los años 70 se incluyeron contenidos curriculares de lo que después se llamaría educación para la democracia, que se cambiaban a medida que se transformaban las ideas sobre la formación cívica o se identificaban nuevas necesidades de enseñanza. 
El gran impulso a la educación para la democracia fue la promulgación de la ley 115 o Ley General de Educación y los decretos y resoluciones que la reglamentaban. Con la ley 115 se buscó descentralizar la educación y otorgarle mayor autonomía a los colegios para definir sus planes curriculares y métodos:

[...] se implementaron una serie de políticas que rediseñaron el concepto de educación para la democracia en Colombia como la evaluación sistemática de los estudiantes (pruebas Saber); y la introducción del concepto de competencias como mecanismos para superar la educación basada en contenidos (Peláez y Márquez, 2006, p. 27).

La resolución 1600 de 1994, el decreto 1860 de 1994, los lineamientos curriculares de Constitución Política y Democracia de 1998, los lineamientos curriculares de 2002 y los estándares curriculares de competencias ciudadanas de 2004, hicieron parte de las medidas del paquete jurídico adoptadas por el Ministerio de Educación colombiano para definir las orientaciones pedagógicas (contenidos, sugerencias metodológicas, evaluación) de la democratización de la vida escolar y la educación ciudadana.

A continuación se analiza brevemente cómo cada una de estas herramientas jurídicas contemplaba de manera explícita estos dos aspectos:

La Ley General de Educación, en el artículo 37, obligó a todas las instituciones a diseñar y poner en práctica un Proyecto Educativo Institucional (PEI). Entre los criterios y los mecanismos que este debía incluir, están los siguientes:

Las nuevas formas de participación del educando dentro del ámbito de la institución educativa, tales como, el Representante de los estudiantes, el Personero de los estudiantes y la participación en el Gobierno Escolar de la Institución.

Los soportes técnico-pedagógicos ya probados en materia de Educación para la Democracia, incluyendo el uso de materiales, medios masivos de comunicación y de la informática.

El Manual de Convivencia y el conjunto de normas de uso institucional (MEN, 1994, p. 34). 
La resolución 1600 de 1994 estableció que cada establecimiento educativo debía tener dentro de su PEI las condiciones para estructurar el proyecto de educación para la democracia y que para ello se debía tener en cuenta:

Que la Constitución Política de Colombia establece como principio fundamental la convivencia democrática en un Estado social de derecho.

Que la misma Constitución Política consagra, de manera particular como fin esencial del Estado, la formación del ciudadano en el respeto a la vida, en la práctica de los derechos humanos, la democracia participativa y la búsqueda de la paz dentro de la convivencia ciudadana.

Que el Artículo 41 de la Carta Fundamental ordena como obligatorios, el estudio de la Constitución y de la Instrucción Cívica en todas las instituciones que presten el servicio de educación formal y el fomento de las prácticas democráticas para el aprendizaje de los principios y valores de la participación ciudadana.

Que la ley 115 de 1994, por medio de la cual se expide la Ley General de Educación, desarrolla estos principios al instituir la obligatoriedad del estudio, la comprensión y la práctica de la Constitución y la Instrucción Cívica y la educación para la Justicia, la Paz, la Democracia, la Solidaridad, la Confraternidad, el Cooperativismo y, en general, la formación en valores humanos.

Que también la Ley General de Educación establece como áreas obligatorias y fundamentales, el estudio de la Constitución Política y la Democracia para el logro de los objetivos en los distintos niveles de la educación formal y crea mecanismos de participación democrática.

Que una de las finalidades del servicio público educativo es la formación en los valores y prácticas democráticas, con el fin de ejercitar al colombiano, desde temprana edad, en la participación en las decisiones que afectan la vida económica, política, administrativa y cultural del país.

Que es necesario contribuir desde la institución escolar, a través de los medios más adecuados, en la formación de una cultura política y democrática para superar las crisis que afecten la convivencia social (sic) (MEN, 1994, p. 2). 
Las orientaciones pedagógicas para lograr las metas planteadas en la Ley General de Educación y la resolución 1600 se consignaron en los lineamientos y estándares curriculares. En la presentación de los lineamientos curriculares de Constitución Política y Democracia quedó consignada la intención de los mismos, "el aprendizaje de la ciudadanía desde las vivencias y no desde el discurso y la necesidad que otras áreas se integraran en el propósito de la formación ciudadana" (MEN, 1998, p. 13). Aunque los autores de estos lineamientos partieron del principio que nadie puede reemplazar a los maestros en el trabajo cuidadoso de pensar y construir los currículos que más convengan a sus condiciones particulares y las características de sus estudiantes, presentaron unas dimensiones, componentes y ámbitos de formación en constitución y democracia para ser tenidos como punto de partida, pero a los cuales podría hacerse permanentes invenciones y las adecuaciones regionales y locales que fueran necesarias. A continuación, un ejemplo:

Cuadro 1. Estándares básicos de competencia de competencias ciudadanas

\begin{tabular}{|c|c|c|}
\hline CONVIVENCIA Y PAZ & $\begin{array}{l}0 \\
\text { PARTICIPACIÓNY } \\
\text { RESPONSABILIDAD } \\
\text { DEMOCRÁTICA } \\
\end{array}$ & $\begin{array}{l}\text { PLURALIDAD, IDENTIDAD Y } \\
\text { VALORACIÓN DE LAS } \\
\text { DIFERENCIAS }\end{array}$ \\
\hline \multicolumn{3}{|c|}{ CONTEXTO } \\
\hline $\begin{array}{l}\text { - Comprendo la importancia de } \\
\text { valores básicos de la } \\
\text { convivencia ciudadana como la } \\
\text { solidaridad, el cuidado, el buen } \\
\text { trato y el respeto por mí mismo } \\
\text { y por los demás, y los practico } \\
\text { en mi contexto cercano (hogar, } \\
\text { salón de clase, recreo, etc.). }\end{array}$ & $\begin{array}{l}\text { - Participo en mi contexto } \\
\text { cercano (con mi familia y } \\
\text { compañeros), en la } \\
\text { construcción de acuerdos } \\
\text { básicos sobre normas para el } \\
\text { logro de metas comunes y las } \\
\text { cumplo. }\end{array}$ & $\begin{array}{l}\text { - Identifico y respeto las } \\
\text { diferencias y semejanzas entre } \\
\text { los demás y yo, y rechazo } \\
\text { situaciones de exclusión o } \\
\text { discriminación en mi familia, } \\
\text { con mis amigas y amigos y en } \\
\text { mi salón. }\end{array}$ \\
\hline \multicolumn{3}{|c|}{ COMPETENCIAS } \\
\hline $\begin{array}{l}\text { - Comprendo que todos los } \\
\text { niños y niñas tenemos derecho } \\
\text { a recibir buen trato, cuidado y } \\
\text { amor. (Conocimientos). } \\
\text { - Reconozco las emociones } \\
\text { básicas (alegría tristeza, rabia, } \\
\text { temor) en mí y en las otras } \\
\text { personas. (Competencias } \\
\text { emocionales). }\end{array}$ & $\begin{array}{l}\text {-Expreso mis ideas, } \\
\text { sentimientos e intereses en el } \\
\text { salón y escucho } \\
\text { respetuosamente los de los } \\
\text { demás miembros del grupo. } \\
\text { (Competencias comunicativas } \\
\text { y emocionales). } \\
\text { - Manifiesto mi punto de vista } \\
\text { cuando se toman decisiones } \\
\text { colectivas en la casa y en la } \\
\text { vida escolar. (Competencias } \\
\text { comunicativas). }\end{array}$ & $\begin{array}{l}\text {-Identifico las diferencias y } \\
\text { semejanzas de género, } \\
\text { aspectos físicos, grupo étnico, } \\
\text { origen social, costumbres, } \\
\text { gustos, ideas y tantas otras } \\
\text { que hay entre las demás } \\
\text { personas y yo. (Competencias } \\
\text { cognitivas y conocimiento). }\end{array}$ \\
\hline
\end{tabular}

Fuente: Ministerio de Educación Nacional, 2003, pp. 16-17 
Los autores de los lineamientos también aclararon que las dimensiones y los componentes que se presentaron obedecieron a razones estrictamente metodológicas, ya que en la realidad estas dimensiones y componentes actúan y se interrelacionan de manera permanente, están completamente ligados y, por lo tanto, del desarrollo de unos depende el avance de los otros (MEN, 1998, p. 51).

Los lineamientos de ciencias sociales completaron un paquete de medidas curriculares con las que se pretendía superar el manejo de las asignaturas de forma aislada y desarticulada. Este abordaje impedía lo que se pretendía con la enseñanza de las disciplinas: "comprender el mundo, vivirlo y transformarlo, dificultaban la promoción de ciudadanos que de manera responsable, justa, solidaria y democrática, intervinieran en su comunidad" (MEN, 2002, p. 4). Según los expertos contratados por el Misterio de Educación, la fundamentación pedagógica de la orientación curricular incluyó las últimas investigaciones de psicología cognitiva y de didáctica de las ciencias sociales; dos puntos de la propuesta eran considerados como los más innovadores: la inclusión de algunas disciplinas que antes no habían sido tenidas en cuenta en la formación primaria y secundaria, como la antropología, la economía, la ciencia política, la sociología y el derecho; y la enseñanza del área a través del abordaje de ejes generadores, preguntas problematizadoras, ámbitos conceptuales, desarrollo de competencias y una estructura integrada, abierta, flexible y en espiral (MEN, 2002).

1. La defensa de la condición humana y el respeto por su diversidad: multicultural, étnica, de género y opción personal de vida como recreación de la identidad colombiana.

2. Sujeto, sociedad civil y Estado comprometidos con la defensa y promoción de los deberes y derechos humanos, como mecanismos para construir la democracia y buscar la paz.

3. Mujeres y hombres como guardianes y beneficiarios de la madre tierra.

4. La necesidad de buscar desarrollos económicos sostenibles que permitan preservar la dignidad humana.

5. Nuestro planeta como un espacio de interacciones cambiantes que nos posibilita y limita.

6. Las construcciones culturales de la humanidad como generadoras de identidades y conflictos.

7. Las distintas culturas como creadoras de diferentes tipos de saberes valiosos (ciencia, tecnología, medios de comunicación).

8. Las organizaciones políticas y sociales como estructuras que canalizan diversos poderes para afrontar necesidades y cambios. 
Lo anterior implicaba que los estudiantes se vieran en la obligación de aprehender marcos teóricos, conceptos, procedimientos y destrezas de diversas áreas del conocimiento para comprender o solucionar las cuestiones y/o problemas planteados. Los nuevos lineamientos curriculares facilitaban la aproximación a temas nunca antes abordados o sencillamente relegados por no corresponder claramente a ninguna asignatura, pero no por ello menos interesantes y válidos para la educación de los alumnos.

El propósito de los estándares de competencias ciudadanas fue la formación, desde la escuela, de individuos con competencias esenciales para el ejercicio de la ciudadanía, como el diálogo, la discusión y el debate en la perspectiva del ejercicio democrático como un espacio de encuentro entre visiones de mundo, de país y de comunidad (MEN, 2004). Este propósito era comprensible si se tiene en cuenta que el contexto del surgimiento de la propuesta de educación para la ciudadanía era el de la búsqueda de la consolidación de la democracia ligada al campo educativo, expresado en la necesidad de formar y educar a los futuros ciudadanos. "Las competencias ciudadanas tal como las planteó el Ministerio de Educación, son el conjunto de conocimientos y habilidades cognitivas, emocionales y comunicativas, que articulados entre sí, hacen posible que el ciudadano actúe de manera constructiva en la sociedad democrática" (MEN, 2004, p. 8). 


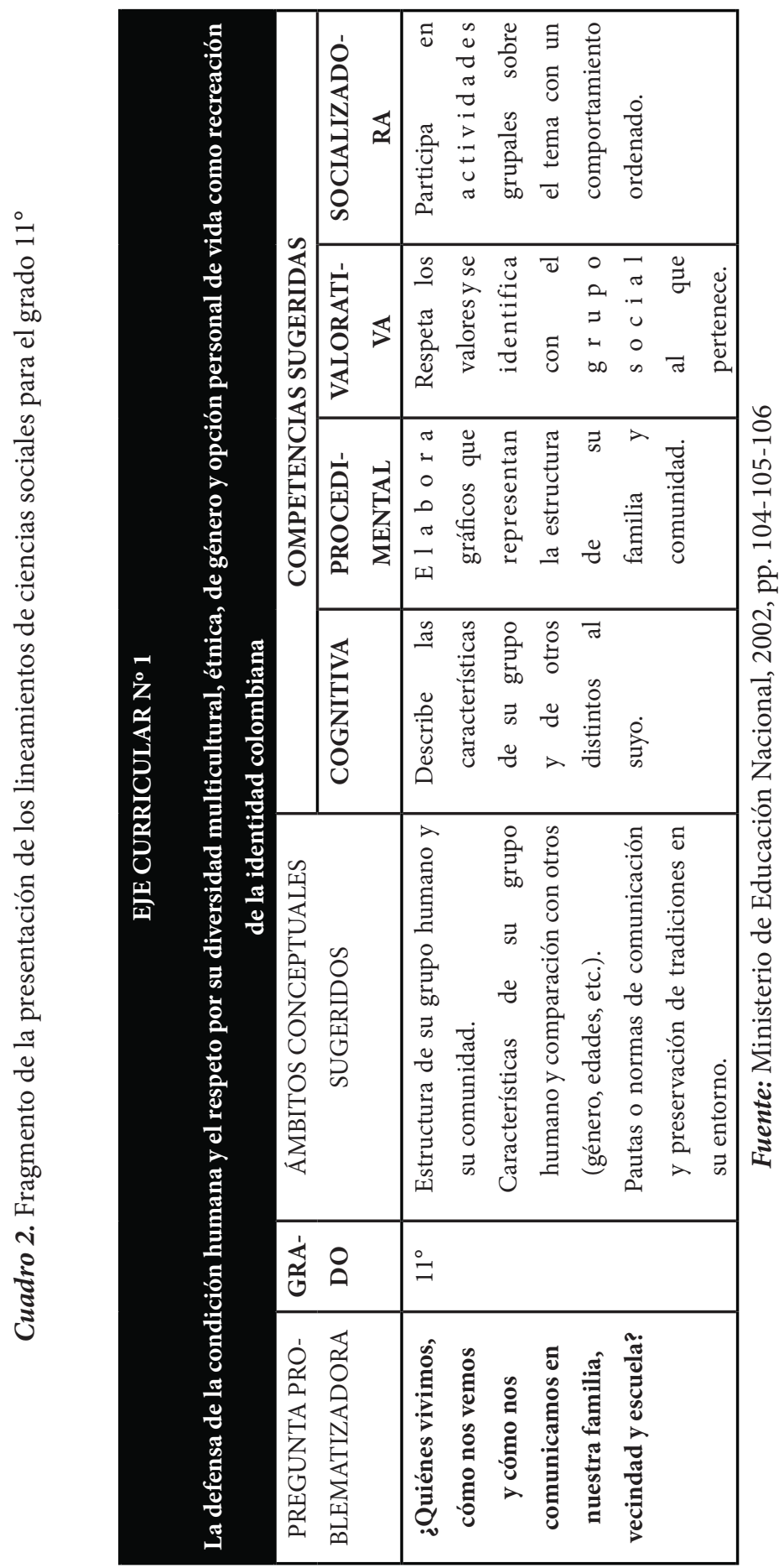


Los estándares de competencias ciudadanas planteados por el Ministerio establecían lo fundamental y lo indispensable que los estudiantes debían saber y saber hacer según su nivel de desarrollo, para desarrollar habilidades para el ejercicio de la ciudadanía en su hogar, en su vida escolar y en otros contextos.

Estos estándares de competencias ciudadanas se organizaron en tres grupos: convivencia y paz; participación y responsabilidad democrática; pluralidad, identidad y valoración de las diferencias. Cada grupo de estándares representa una dimensión fundamental para el ejercicio de la ciudadanía y contribuye a la promoción, el respeto y la defensa de los derechos humanos presentes en la constitución nacional. Además desde cada uno de ellos, se debían ejercitar competencias emocionales, comunicativas e integradoras. El documento del ministerio organizó los estándares por grupos de grados: primero a tercero, cuarto y quinto, sexto y séptimo, octavo y noveno, decimo y once; cada grupo de competencias está encabezado por un estándar general y abarcador y bajo este enunciado se presentan los estándares de competencias básicas necesarios para lograr la competencia ciudadana que encabeza la lista, al lado de cada estándar se encuentran los íconos y los colores que ayudan a identificar qué tipo de competencia está en juego (MEN, 2004, p. 12).

El documento hizo algunas aclaraciones para facilitar el trabajo de los maestros: sugirió que la secuencia de los grupos de competencias y los estándares no significaba que debieran trabajarse en el mismo orden; que los tres grupos de estándares están separados pero que en la vida real y en el trabajo en la institución educativa se podían presentar múltiples intersecciones; que la clase no es el único escenario para el desarrollo de las competencias ciudadanas. El descanso, izadas de bandera, actos culturales y deportivos, también podrían ser útiles para este propósito. Finalmente aclaraba que si bien las clases como Ética y valores o Constitución y democracia podían ser espacios de trabajo, también lo eran las otras asignaturas, como Matemáticas, Lengua castellana, Ciencias naturales. Con esto último el Ministerio resaltó la transversalidad que había detrás de los estándares básicos de competencias ciudadanas (Palacios, 2013).

Una mención especial en este paquete de medidas jurídicas encaminadas a modificar el currículo y la organización social de los establecimientos educativos, merece el decreto 1860 de 1994, por medio del cual se reglamentó parcialmente la Ley 115 de 1994. En los aspectos pedagógicos y organizativos generales, el decreto exigió la obligatoriedad del Manual de Convivencia para todas las instituciones públicas o privadas del país. Algunos de sus apartes son los siguientes: 
Artículo 17. Reglamento o manual de convivencia. De acuerdo con lo dispuesto en los artículos 73 y 87 de la Ley 115 de 1994, todos los establecimientos educativos deben tener como parte integrante del Proyecto Educativo Institucional un reglamento o manual de convivencia. El reglamento o manual de convivencia debe contener una definición de los derechos y deberes de los alumnos y de sus relaciones con los demás estamentos de la comunidad educativa. En particular debe contemplar los siguientes aspectos:

1. Reglas de higiene personal y de salud pública que preserven el bienestar de la comunidad educativa, la conservación individual de la salud y la prevención frente al consumo de sustancias psicotrópicas.

2. Criterios de respeto, valoración y compromiso frente a la utilización y conservación de los bienes personales y de uso colectivo, tales como equipos, instalaciones e implementos.

3. Pautas de comportamiento en relación con el cuidado del medio ambiente escolar.

4. Normas de conducta de alumnos y profesores que garanticen el mutuo respeto. Deben incluir la definición de claros procedimientos para formular las quejas o reclamos al respecto.

5. Procedimientos para resolver con oportunidad y justicia los conflictos individuales o colectivos que se presenten entre miembros de la comunidad. Deben incluir instancias de diálogo y de conciliación.

6. Pautas de presentación personal que preserven a los alumnos de la discriminación por razones de apariencia.

7. Definición de sanciones disciplinarias aplicables a los alumnos, incluyendo el derecho a la defensa.

8. Reglas para la elección de representantes al Consejo Directivo y para la escogencia de voceros en los demás consejos previstos en el presente decreto. Debe incluir el proceso de elección del personero de los estudiantes (MEN, 1994, p. 9- 10).

Según Palacios (2008), el decreto fue publicado siguiendo el principio de que la concertación entre maestros, directivos y estudiantes debe garantizar en gran parte el cumplimiento de la norma, bajo el supuesto de que cuando una persona puede 
aportar su opinión para elaborar una norma y se le proporcionan las justificaciones de su importancia, dicha persona termina por aceptarla y respetarla. Además de la novedad del nombre "Manual de Convivencia" en reemplazo de "Reglamento Escolar de Disciplina" y de los requisitos de 1) amplia participación de (toda) la comunidad educativa, 2) revisión del documento por parte de una autoridad con conocimiento en derechos humanos, y 3) la aprobación del Consejo Directivo de la Institución, en términos generales el Manual instituía normas y reglas, buscaba definir las reglas de organización y funcionamiento de una institución, e intentaba normalizar las prácticas y los discursos. A través del Manual se organizan un conjunto de normas que se pretenden universales y válidas para todos los miembros de la comunidad educativa.

Si bien muchos sectores reconocieron el esfuerzo del Estado para proporcionar unas directrices básicas para la educación democrática y ciudadana, y valoraron el hecho de no dejar solamente enunciada los documentos y sus metas, no faltaron las críticas a la política pública. Pinilla y Torres (2006), identificaron tres debilidades en los estándares: la ausencia de reflexión teórica y pedagógica sobre la ciudadanía y la formación ciudadana, la ausencia de un eje articulador que orientara las acciones que podían desarrollarse en las competencias ciudadanas y la ausencia de propuestas pedagógicas para el desarrollo mismo de la guía que se propuso. Por su parte, Perafán y Mejía (2006), concluyeron que en la propuesta gubernamental entendían el ejercicio de la ciudadanía como el desempeño de un conjunto de competencias aptas para mantener una sociedad democrática en un estado ideal donde siempre puede haber comprensión mutua y los conflictos son reconciliables mediante el diálogo en forma expedita y racional. También donde existen mecanismos genuinos de participación y las distorsiones a las democracias son transparentes y fácilmente identificables. Resaltan estos autores que esa imagen de la democracia no correspondía a la sociedad colombiana del momento y si bien había que perseguirla, se debía educar para la vida en una sociedad imperfecta. Para Perafán y Mejía (2006), esta falla se podía subsanar si se redefinían las competencias ciudadanas desde una perspectiva crítica.

En este breve compendio de las reformas educativas, no podía faltar el recurso jurídico de la tutela. Para muchos, los fallos de tutela emitidos por la Corte Constitucional y por jueces de diferentes niveles en todo el país, han logrado influir y transformar la escuela, más que los decretos, las resoluciones y los planes y programas del Ministerio de Educación. Este fenómeno fue denominado por Cortés (2012), "la pedagogización de la ley y la juridización de la escuela". En un extenso estudio desde la perspectiva genealógica y arqueológica de Michelle Foucault, Cortés logró 
demostrar que antes de que aparecieran tecnologías de formación que pretendieron tramitar pedagógicamente el conflicto dentro de la escuela e incluso fuera de ella, fue una instancia de orden jurídico, la Corte Constitucional, la que empezó a regular la convivencia escolar.

La Corte es un organismo perteneciente a la rama judicial del Poder Público, creado por la Constitución Política, y a la que se le confió la guarda de la integridad y supremacía de la Carta. Una de sus funciones, descrita en el artículo 241, consiste en decidir sobre las demandas de constitucionalidad que promueven los ciudadanos contra las leyes, los decretos con fuerza de ley dictados por el gobierno y los actos legislativos reformatorios de la Constitución. La acción de tutela se estableció en 1991 como instrumento para la protección de los derechos fundamentales consagrados en la Constitución Política, y ha tenido como fin expreso la protección inmediata de los derechos fundamentales cuando éstos resultaran vulnerados o amenazados por la acción u omisión de cualquier autoridad pública o por particulares encargados de la prestación del servicio público. Es la Corte Constitucional la encargada de revisar la acción de tutela y dictar sentencia o emitir fallo (Cortés, 2012, p. 242).

La entrada y permanencia de los niños y jóvenes al sistema educativo fue reconocido como derecho fundamental en la Constitución. Este y otros derechos como el libre desarrollo de la personalidad, el debido proceso y la libertad de culto, fueron los más exigidos por estudiantes y padres de familia en las acciones de tutela presentadas. Pero el poder de lo jurídico vía acción de tutela no se restringió al campo de la relaciones entre docentes, directivos y estudiantes, sino que tocaron el centro mismo de la formación de los estudiantes. Aspectos como el aula de clases, las formas de evaluación, las metodologías y recursos de la enseñanza, los planes de estudio, el calendario escolar, el llamado a lista, los criterios de promoción y reprobación de un grado, los costos educativos, los reglamentos, los cronogramas de actividades, los organigramas institucionales y las pruebas de admisión, fueron objetos de revisión y análisis como consecuencia de la lluvia de tutelas que invadió los juzgados del país a partir de la promulgación de la Carta de 1991. Según Palacios (2008), tanto los padres como los estudiantes se apropiaron de la tutela, que fue considerada la acción legal más efectiva para que los planteles educativos cumplieran con lo establecido en la legislación educativa y en la Constitución Nacional. Gracias a ella muchos niños y jóvenes consiguieron permanecer en el sistema educativo y numerosos establecimientos se vieron obligados a revisar sus reglamentos escolares. 
En una revisión hecha por los investigadores Marlene Sánchez y Carlos Noguera (2002), se estableció que entre 1992 y 1998, el 51.8\% de las tutelas solicitadas correspondían al sector educativo en todos sus niveles; de éstas, el $45.2 \%$ procedían de estudiantes, padres y docentes de básica secundaria y media vocacional; el 26.3\% de educación superior y el 18\%, del nivel de básica primaria y preescolar. Entre el año 1992 y el 2006, llegaron hasta la Corte Constitucional aproximadamente 146 tutelas1, cuyos argumentos invocaban el derecho a la educación, a la igualdad, al libre desarrollo de personalidad, al debido proceso, o algún otro derecho de los que han sido reivindicados en el contexto de la democratización de la vida escolar. Todas las tutelas revisadas exigían el derecho a la educación, pero en su mayoría complementaban el alegato con otras exigencias. Los niños, jóvenes, padres de familia, pero también los maestros, introdujeron la tutela a la institución escolar e hicieron de ella una herramienta que permitió la expedición de nuevos manuales de convivencia, fomentando la creación e institucionalización de las normas en los establecimientos educativos.

Gracias a fallos de tutela, escenas que antes no eran toleradas en los establecimientos educativos se volvieron comunes. En los establecimientos femeninos, estudiantes embarazadas; en los masculinos, estudiantes con cabello largo y/o aretes, y en ambos casos se flexibilizó el uso de un uniforme asignado por la institución y se permitió el uso de accesorios nunca antes vistos como pearsings, correas, collares $\mathrm{u}$ otros adornos. Vale la pena decir que en muchas instituciones no fueron bienvenidas las sentencias de la Corte, y ni siquiera la instauración de las tutelas. Varios estudios mostraron que después de promulgada la ley y de varios fallos de la Corte Constitucional, algunos establecimientos se mostraron renuentes a acatar dichas disposiciones. Se hizo evidente la resistencia de muchos colegios para aceptar la normatividad, lo que explica la repetida instauración de tutelas con el mismo reclamo entre los años 95 y 2000. Para algunos docentes y directivos este mecanismo era inaceptable, y lo responsabilizaron de la "insubordinación" de los estudiantes, de su desobediencia y de su indisciplina. Algunos docentes que no compartían las disposiciones de la Corte la tildaron de irresponsable, mientras que para otros la "permisividad" expresada en los fallos se debía a que los magistrados desconocían el trabajo de los docentes y la realidad interna de la escuela (Palacios, 2008).

1 Muchas tutelas no llegan hasta esta instancia; son falladas por los jueces departamentales y municipales sin que se produzca apelación. Solo llegan a la Corte Constitucional algunas tutelas elegidas por sorteo, o por solicitud expresa de otro juez de la República. 


\section{CONCLUSIONES}



La reconstrucción socio histórica de la coyuntura en la cual emergió el discurso de los derechos en la escuela colombiana, permitió concluir que dicho discurso se instauró en el marco del proyecto gubernamental de democratización de la misma, que pretendía eliminar las prácticas antidemocráticas y de autoritarismo identificadas en los colegios y contribuir a la construcción de la paz y fortalecimiento de la democracia en el país. Desde un enfoque de formación para la ciudadanía, que promueve la horizontalidad en las relaciones sociales, la participación, la solución de conflictos y la promoción y protección de los derechos en cualquier ámbito.

La democratización de la escuela propuso la redefinición de las relaciones de poder entre los estudiantes y las autoridades escolares: el reconocimiento de los derechos de todos los integrantes de la comunidad educativa, la creación de organismos de gobierno escolar alumnos, padres de familia, exalumnos y miembros del entorno educativo tuvieran participación y la elaboración de decretos, resoluciones y directivas en los que se proponía pasar de regímenes disciplinarios a instrumentos que favorecieran la convivencia escolar. También se implementaron reformas curriculares que institucionalizan como ejes de la enseñanza el respeto por la diferencia, la paz, la identidad, el libre desarrollo de la personalidad, la libertad y la autonomía moral. El proyecto democratizador partió de la concepción de que la democracia en la escuela se construía justamente a partir del reconocimiento pleno de los derechos y de la adquisición por parte de padres de familia y estudiantes del estatus de protagonistas. Esto suponía un cambio del rol del maestro, que ahora debía ser el dinamizador del proceso de aprendizaje, con los alumnos como centro de la enseñanza y actores más importantes de la institución escolar. 
La democratización privilegió la protección de los derechos pero no dio igual importancia a la promoción de los deberes. Al igual que en otras reformas educativas, la implementación del proyecto de democratización de la vida escolar ha privilegiado un enfoque legalista, con la promulgación de leyes normas o regulaciones prescriptivas que suponen la aceptación y el cumplimiento por parte de los actores educativos.

El énfasis dado por el proyecto democratizador a la promulgación y publicación de un marco jurídico y a la promoción de la convivencia a través de múltiples actividades de diversos enfoques y con la participación de distintos actores, no dio un espacio suficiente a los debidos reflexión y seguimiento a los procesos. Esto hizo evidente que, de la escuela antidemocrática y autoritaria, se pasó a una escuela donde aflora permanentemente el conflicto entre los actores educativos sin que se le dé un tratamiento pedagógico. La consecuencia es la ausencia de ambientes adecuados para el aprendizaje. Los datos recogidos para esta investigación evidenciaron que el caos que se ha generado en algunos establecimientos educativos, sencillamente imposibilita procesos de enseñanza-aprendizaje y la producción y circulación de conocimientos.

Con lo anterior no se pretende señalar que haya sido negativo abrir espacios de participación o haber promovido derechos en la escuela; lo que hay que resaltar es la falta de un trasfondo pedagógico real que se tradujera en la transformación de prácticas y discursos en las instituciones educativas. A esto se debe sumar la vivencia de la democracia como una experiencia que se construye cada día, en un ambiente donde la emergencia del conflicto tuviera un tratamiento pedagógico. $\mathrm{Si}$ bien esta intención pudo hacer parte del proyecto democratizador, no fue eso lo que ocurrió en el día a día de la cotidianidad de la escuela.

Uno de los obstáculos del proyecto democratizador es que su enfoque trasversal no se pudo cristalizar. Sin negar la existencia de experiencias exitosas y el compromiso decidido de padres y estudiantes por aprovechar los espacios de participación que ahora tienen (como muestran los casos de los personeros y el contralor estudiantil de los colegios estudiados), la democracia quedó relegada a ser un tema de los profesores de ciencias sociales, un asunto electorero y de cumplimiento de requisitos como la conformación de órganos de gobierno escolar y la ejecución de actividades de promoción de derechos y de convivencia. Lo que se llevó a cabo se hizo generalmente de manera desarticulada y sin un proceso de seguimiento y evaluación. 
Cuando se hace el análisis de los resultados que se obtuvieron sobre la efectividad de las acciones implementadas para democratizar la escuela, se pudo establecer que muy pocas instituciones demuestran haber entendido la democracia como una experiencia que se construye día a día. Los docentes de las demás áreas obligatorias y optativas, no sólo no incluyeron en sus prácticas los componentes del proyecto democratizador, sino que lo consideraban un asunto ajeno a su responsabilidad. 



\section{REFERENCIAS}

Aguilar, J. F. y Betancourt, J. (1999). Proceso de construcción de cultura democrática en instituciones educativas de Santa Fe de Bogotá. Informe final de investigación. CEPECS- IDEP.

Álvarez, A. (2001). Del estado docente a la sociedad educadora. ¿Un cambio de época? Revista Iberoamericana de educación OEI. Número 26. Disponible en: www.rieoei.org/rie26f.htm. Consultado en marzo de 2014.

Arboleda, G. (1994). Mejoramiento de la calidad de la educación. Revista Educación y Cultura. Número 36 - 37. Memorias II Congreso Pedagógico Nacional. Bogotá. FECODE. Pág. 27 - 32. Disponible en: http://www. mineducacion.gov.co/normatividad/1753/w3-article-103537.html. Consultado en marzo de 2013.

Aristóteles (1988). La Política. Bogotá: Ed Gredos.

Austin, J. L. (1962). Cómo hacer cosas con palabras. Barcelona: Paidós.

Ausubel, D. (1983). Aprendizaje significativo. Psicología Educativa: Un punto de vista cognositivo. México: TRILLAS. 
Beatriz, S. (1996). Educación Latinoamericana a fines de siglo. Archivos del presente. Año 2. Volumen 6. Buenos Aires.

Bertuccelli, M. (1993). Qué es la pragmática. Barcelona: Paidós.

Blum-Kulka, S. (1999). Pragmática del discurso. En Van Dijk, T. A. El discurso como interacción social, vol. 2, Barcelona: Gedisa.

Brunner, J. (1988). Desarrollo Cognitivo y Educación. Selección de Textos por Jesús Palacios. España: Ediciones Morata.

Caballero, P. (1994). La reforma educativa en Colombia. Revista Educación y Cultura. N ${ }^{\circ} 36$ - 37. Memorias II Congreso Pedagógico Nacional. Bogotá: FECODE. Páginas. 21 - 27. Castellana: Áreas obligatorias y fundamentales. Santafé de Bogotá D.C.

Comenio, J. A. (1988). Didáctica Magna. México: Porrúa. Colección Sepan Cuántos.

Constitución Política de Colombia (1991). Disponible en: http://Constitutions/ Colombia/colombia91.pdf. Consultado en junio de 2014.

Cortés, A. (2012). Prácticas de ciudadanización en la escuela contemporánea, Colombia 1984 - 2004.Tesis para optar por el título de doctora en educación. Universidad Distrital. Universidad del Valle.

Cubides, H. (2000). El gobierno escolar y la educación ciudadana. Estudio de Casos. Informe final de investigación. Bogotá. IDEP.

Cumbre Iberoamericana (1997). Los valores éticos de la democracia. Declaración De Isla Margarita Venezuela. OEI. Disponible en: http://www.oei. es/viicumbre.htm Consultado en abril de 2014. 
Declaración Mundial sobre la educación para todos (1990). Marco de acción para satisfacer las necesidades básicas de aprendizaje. Jomtien. Tailandia. Disponible en: http://www.unesco.org/education/pdf/JOMTIE_S.PDF. Consultado en marzo de 2014.

Delgado, R., Vargas, M., Vives, M., Manrique, L., Lara, L. M. y Arias, R. (2005). Educación para el conocimiento social y político. Estado del arte. Bogotá: Universidad. Disponible en: Javeriana. http://www.javeriana.edu.co/Facultades/ Educacion/html/programa/maestria/II-07/documentos/social-ea-05.pdf. Consultado en abril de 2013.

Delpiano, A. y Madnenzo, A. (1998). La escuela formal, el curriculum escolar y los derechos humanos. La educación y los derechos humanos. Revista educación y cultura Número 16. Bogotá: FECODE. pp. 5-8.

Dewey, J. (1934). El arte como experiencia. Barcelona: Ediciones Paidós Ibérica, S, A.

Dewey, J. (1995). Democracia y educación Una introducción a la filosofía de la educación. Ediciones Morata. Madrid.

Díaz-Barriga, A. F. (s.f). Enseñanza situada: vínculo entre la escuela y la vida. Mc Graw Hill, México.

Dilthey, Wilhelm (1980). Introducción a las ciencias del espíritu. Madrid: Alianza.

Egan, K. (1999). Fantasía e imaginación: su poder en la enseñanza. USA: University.

Escandell, M. V. (1996). Introducción a la pragmática. Anthropos: Madrid. 
Federación Colombiana de Maestros. FECODE (1998). La educación y los derechos humanos. Revista educación y cultura, Número 16. Bogotá.

Ferreiro E. (2013). Ingreso a la escritura y a las culturas de lo escrito. Textos de investigación. México: Siglo XXI editores.

Foro Mundial Sobre la Educación (2000). Educación Para Todos: Cumplir nuestros compromisos comunes. Marco de Acción de Dakar, Senegal. Disponible en: http://unesdoc.unesco.org/images/0012/001202/120240s.pdf. Consultado en marzo de 2013.

Foucault, Michel (1999). Arqueología de las ciencias humanas. México: Editorial Siglo XXI.

Freire, P. (1970). Pedagogía del oprimido. Uruguay: siglo XXI Editores s. a. de c. v.

Gallón, G. y Uprimny, R. (1990). Constituyente, violencia y derechos humanos. Revista Foro. Número 13. En: Valencia, Alberto. (1998). Violencia en Colombia en los años 80 y reforma constitucional. Santiago de Cali. Editorial Universidad del Valle.

Gardner, H. (1999). Intelligence Reframed Multiple Intelligences for the 21st Century. II Conferencia Iberoamericana de Educación. (1992). Guadalupe España. Disponible en: OEIhttp://www.oei.es/iicie.htm. Consultado en marzo de 2013.

Gajardo, M. (1999). Reformas Educativas en América Latina. Balance de una década. Número 15. Programa de promoción de la reforma educativa en América Latina y el Caribe. PREAL 
Guzmán, C. (2005). Reformas educativas en América Latina. Un análisis crítico. Revista Iberoamericana de Educación OEI. Número 10. Volumen 8.

Lipovetsky G. (2007). La felicidad paradójica: Ensayo sobre la sociedad de hiperconsumo. Francia: Anagrama.

MacLean P.D. (1973). A triune concept of the brain and behavior. Toronto: University.

Manrique, F. (1994). El nuevo papel de la educación en el entorno competitivo colombiano. Revista Educación y Cultura. Número 36 - 37. Memorias II Congreso Pedagógico Nacional. Bogotá. FECODE.

Martínez, H. y Martínez, E. (1998). La educación y los derechos humanos. Revista educación y cultura, Número 16. Bogotá: FECODE. Disponible en: http:// investigaciones.usbcali.edu.co/ockham/images/volumenes/Volumen2N1/ V2N01-02_Conflicto_violencia_escolar.pdf. Consultado en marzo de 2013.

Maturana, H. (1990). Emociones y lenguaje en educación y política. España: Dolmen Ediciones.

Melo, J. O. (2002). Educación para la ciudadanía: ¿Nueva encarnación para un viejo ideal? Revista educación integral. 56 año $11 \mathrm{~N}^{\circ} 15$. Disponible en: http:// www.mineducacion.gov.co/1621/articles-81037_archivo.pdf. Consultado en abril de 2013.

Mesa, J. A. (2004). Tendencias actuales en la educación moral. En: Cortés, Amanda. (2012). Prácticas de ciudadanización en la escuela contemporánea, Colombia 1984 - 2004. Tesis para optar por el título de doctorado en educación. Universidad Distrital. Universidad del Valle. 
Michel, J. (2004). Políticas educativas en América Latina (Década de los 90, momento de consenso social). Revista de teoría y didáctica de las ciencias sociales. Número 9. Universidad de los Andes Mérida Venezuela.

Ministerio de Educación Nacional de Colombia (1978). Decreto 1419, "Por el cual se señalan las normas y orientaciones básicas para la administración curricular en los niveles de educación pre-escolar (primaria y secundaria) media vocacional e intermedia profesional". Disponible en: http://www.mineducacion. gov.co/1621/articles-102770_archivo_pdf.pdf. Consultado en marzo de 2014.

Ministerio de Educación Nacional de Colombia (1984). Decreto 1002, "Por medio del cual se establece el plan de estudios para la educación preescolar, básica (primaria y secundaria) y media vocacional de la educación formal. Disponible en: http://www.mineducacion.gov.co/1621/articles-103663_ archivo_pdf.pdf. Consultado en marzo de 2014.

Ministerio de Educación Nacional de Colombia (1989). Educación en y para la democracia. Disponible en: http://www.mineducacion.gov.co/1621/ propertyvalue-31215.html. Consultado en marzo de 2014.

Ministerio de Educación Nacional de Colombia (1993). Estudios sobre lógica y psicología. Madrid: ediciones Altaya.

Ministerio de Educación Nacional de Colombia (1994). Ley 115 o Ley General de Educación. Disponible en: http://www.mineducacion.gov.co/1621/ articles-85906_archivo_pdf.pdf. Consultado en marzo de 2014.

Ministerio de Educación Nacional de Colombia (1994). Ley General de Educación. Bogotá: Editorial Unión Ltda.

Ministerio de Educación Nacional de Colombia (1995). El abecé de la pragmática. Madrid: Arco Libros. 
Ministerio de Educación Nacional de Colombia (1996). Resolución 2343. Santafé de Bogotá.

Ministerio de Educación Nacional de Colombia (1997). Decreto 2082. Santafé de Bogotá.

Ministerio de Educación Nacional de Colombia (1997). Decreto 2247. Santafé de Bogotá.

Ministerio de Educación Nacional de Colombia (1998). Lineamientos curriculares de constitución política y democracia. Disponible en: http://www. mineducacion.gov.co/1621/articles-339975_recurso_3.pdf. Consultado en marzo de 2014.

Ministerio de Educación Nacional de Colombia (1998). Lineamientos Curriculares, del preescolar.

Ministerio de Educación Nacional de Colombia (1998). Lineamientos Curriculares de Lengua Castellana.

Ministerio de Educación Nacional de Colombia (2001). Memorias del Seminario Internacional de Educación Ciudadana Educación ciudadana. Desafío social. Bogotá: Generar ediciones. Disponible en: http://www.mineducacion.gov. co/1621/articles-81037_archivo.pdf. Consultado en marzo de 2014.

Ministerio de Educación Nacional de Colombia (2002). Lineamientos curriculares de ciencias sociales. Disponible en: http://www.mineducacion.gov. co/1621/article-87874.html. Consultado en marzo de 2014.

Ministerio de Educación Nacional de Colombia (2002). Revolución educativa, Política de ampliación de la cobertura escolar. Disponible en: http://www. mineducacion.gov.co/1621/w3-article-179334.html. Consultada en mayo de 2014. 
Ministerio de Educación Nacional de Colombia (2004). Estándares de competencias ciudadanas. Disponible en: http://www.mineducacion.gov. co/1621/articles-75768_archivo_pdf.pdf. Consultado en marzo de 2014.

Ministerio de Educación Nacional de Colombia (2007). Ley 1145. Santafé de Bogotá.

Ministerio de Educación Nacional de Colombia (2009). Decreto 366. Santafé de Bogotá.

Ministerio de Educación Nacional de Colombia (2009). Documento 10. Desarrollo infantil. Bogotá.

Ministerio de Educación Nacional de Colombia (2011). Decreto 4807 de 2011 "que establece las condiciones de aplicación de la gratuidad educativa para los estudiantes de educación preescolar, primaria, secundaria y media de las instituciones educativas estatales". Disponible en: Htp://www.mineducacion. gov.co. Consultada en mayo de 2014.

Mena, P. N. (2013). La relación entre la norma y el conflicto disciplinario en las instituciones educativas. Un estudio de caso. En Variables psicológicas y educativas para la intervención en el ámbito escolar. Coordinadoras Universidad de Almería.

Ministerio de Educación Nacional de Colombia (2014). Documento 21. El arte en la educación

Ministerio de Educación Nacional de Colombia Plan decenal de educación 1996 - 2005. Disponible en: http://www.plandecenal.edu.co/html/1726/ articles-121191_archivo.pdf. Consultado en marzo de 2014. 
Ministerio de Educación Nacional de Colombia (1994). Resolución 1600. Proyecto de educación para la democracia. Disponible en: http://www.col. ops-oms.org/juventudes/Situacion/LEGISLACION/EDUCACION/ER160094. HTM. Consultado en marzo de 2014.

Montes de Oca, B. (1994). Reformas educativas en Colombia. Revista Educación y Cultura. Número 36 - 37. Memorias

Ministerio de Educación Nacional de Colombia II Congreso Pedagógico Nacional. Bogotá: FECODE.

Montessori, M. (1936). The secret of childhood. India: B.R. Mundhra at Binani. Murillo, F. (1994). Una nueva ley de educación, en un nuevo país. Revista Educación y Cultura. Número 36 - 37. Memorias II Congreso Pedagógico Nacional. Bogotá: 1994. FECODE. Págs. 52 - 58.

Navarro, J. (2006). El estado de las reformas del Estado en América Latina. Editado por Eduardo Lora. Mayol Ediciones.

Nieves, C. (1994). Una reforma de largo alcance. Revista Educación y Cultura. Número 36 - 37. Memorias II Congreso Pedagógico Nacional. Bogotá: 1994. FECODE. Págs. 59-61.

Palacios, N. (2008). Disciplina, norma y democracia sus concepciones y funcionamientos en la cotidianidad de la escuela. Trabajo de grado para optar por el título de magister en sociología. Facultad de Ciencias Sociales y Económicas. Universidad del Valle.

Peláez, A. y Márquez, D. (2006). Educación para la democracia y la formación politica en Colombia: 1980 - 2006. Un estado del arte. Bogotá. Fundación Konrad Adenauer. 
Perafán, B. y Mejía, A. (2006). Para acercarse al dragón, para amansarlo, es necesario haberlo amansado primero. Una mirada crítica de las competencias ciudadanas. Revista de Estudios sociales. Universidad de los Andes. Bogotá.

Piaget, J. (1959). La formación del símbolo en el niño. México: Fondo de cultura económica.

Piaget, J. (1977). El nacimiento de la inteligencia en el niño. Barcelona: Editorial Crítica.

Piaget, J. (1993). Estudios sobre lógica y Psicología. Madrid: Ediciones Altaya.

Pineda, J. A. y García, F. (2014). Convivencia y discurso en el espacio escolar. Discursos y realidades. XIII Coloquio Internacional de Geo crítica. El control de espacio y los espacios de control. Universidad de Barcelona. Disponible en: http://www.ub.edu/geocrit/coloquio2014/Jose\%20Antonio\%20Pineda\%20 Alfonso.pdf. Consultado en junio de 2014.

Pinilla, A. y Torres, J. C. (2006). De la educación para la democracia a la formación ciudadana: Una década de incertidumbres. Bogotá: Instituto para la investigación educativa y el desarrollo pedagógico. IDEP.

Piñón, F. (1989. La educación como herramienta estratégica. Boletín 45 Proyecto principal de educación en América Latina y el Caribe. UNESCO. Oficina Regional de Educación para América Latina.

Platón (1966). La República. Colombia: Atenea. Printers. New York: Basic Books.

Quintana, M. F. (1996). Regulación de conflictos. Convivir una experiencia con comunidad educativa. Vargas, Mercedes, Coordinadora. Morales, Carlos, 
Quintana, María Fernanda. Bogotá: Ministerio de Educación de Colombia. Organización de Estados Americanos. Instituto para el Desarrollo de la Democracia Luis Carlos Galán. pp. 65- 81. Disponible en: http://www. congresoed.org/wp- content/uploads/2013/09/06comunicaciones.pdf. Consultado en marzo de 2014.

República de Colombia (1991). Constitución Política de Colombia. Santafé de Bogotá.

Reyes, G. (1990). La pragmática lingüística. Barcelona: Montesinos.

Rincón, L. M., Bogotá, M., Sabogal, L., Vargas, E. (2001). Bogotá Nuestra Ciudad. Centro de Procesos de formación Ciudadana Colegio Distrital Atanasio Girardot. Informe de investigación. Instituto para la Investigación Educativa y el desarrollo Pedagógico, IDEP.

Rodríguez, Á. (1998). Formación democrática y educación cívica en Colombia. Un estudio nacional de caso. Ministerio de Educación Nacional. Bogotá.

Sáenz, J. (1988). Currículo oculto: Democracia y formación moral en la escuela. Revista educación y cultura $\mathrm{N}^{\circ} 16$. Bogotá: FECODE. pp. 14- 20. Disponible en: http://www.albertomartinezboom.com/curriculum/curriculum.pdf. Consultado en marzo de 2013.

Sánchez, G. (2009). Colombia: Violencia y democracia. Comisión de estudios sobre la violencia. Medellín: La carreta Editores.

Sánchez, M. y Noguera, C. (2002). La acción de Tutela en la educación. En: Rodríguez, Abel. La Educación Después de la Constitución del 91. De la reforma a la contrarreforma. Bogotá. Editorial Magisterio. Corporación Tercer Milenio. 
Serna, A. (2007). Ontologías alternativas, apertura al mundo desde el giro lingüístico. Barcelona: Anthopos.

Skinner, B. (1974). Sobre el conductismo. Martínez Roca. Argentina: Editorial Planeta.

Valencia, A. (1998). Violencia en Colombia en los años 80 y reforma constitucional. Editorial Universidad del Valle, Santiago de Cali.

Southwell, M. (2015). Infancias, escuela y educación: una mirada entre generaciones. Revista Diálogos sobre educación. Temas actuales de investigación educativa. Universidad de Guadalajara. Centro Universitario de Ciencias Sociales y Humanidades. Departamento de Estudios en Educación Año 6. Número 10, pp-1-4.

Vargas, M. (1996). El trabajo con la comunidad educativa: una propuesta de sentido y método. Convivir una experiencia con comunidad educativa. Vargas, Mercedes. Coordinadora. Morales, Carlos, Quintana, María Fernanda. Bogotá. Ministerio de Educación de Colombia. Organización de Estados Americanos. Instituto para el Desarrollo de la Democracia Luis Carlos Galán.

Verschueren, J. (1999). Para entender la pragmática. Madrid: Gredos, 2002.

Verspoor, M. (2000). Explorations in linguistic relativity. John Benjamins Publishing Company.

Vygotsky, L. (1987). Pensamiento y Lenguaje. México: Ediciones Quinto Sol. Vygotsky, L. (2005). La imaginación y el arte en la infancia. México: Ediciones Coyoacán S. A de C. V.

Whorf, B. L. (1957/1971). Language, Thought and Reality. Cambridge, MA: The M.I.T. Press. (Versión castellana en Barral Editores, de Barcelona, en 1971). 
Yáñez, J. y Fonseca, M. A. (2003). Teorías y narraciones sobre la educación moral. En: Cortés, Amanda. (2012). Prácticas de ciudadanización en la escuela contemporánea, Colombia 1984-2004.Tesis para optar por el título de doctorado en Educación. Universidad Distrital. Universidad del Valle.

Yule, G. (1996). Pragmatics. Oxford: Oxford University Press.

Yusti, L. N. (1992). ¿Cumplen los castigos una función educativa? Memorias III Congreso Colombiano de Orientación Educativa. Armenia. FES. Universidad del Quindío.

Zaccagini, M. (2004). Reformas educativas: espejismos de innovación. Revista Iberoamericana de Educación. Número 36.

Zafra, D. (1998). La educación y los derechos humanos. Revista Educación y Cultura $N^{\circ}$ 16. Bogotá: FECODE. pp. 11- 20. 
Este libro terminó de diagramarse en junio del 2017, en el Centro de Recursos Informaticos y Educativos de la UTP, bajo el cuidado de las autoras.

Pereira, Risaralda, Colombia. 
La Editorial de la Universidad Tecnológica de Pereira tiene como política la divulgación del saber científico, técnico y humanístico para

fomentar la cultura escrita a través de libros y revistas científicas especializadas.

Las colecciones de este proyecto son: Trabajos de Investigación, Ensayos, Textos Académicos y Tesis Laureadas.

Este libro pertenece a la Colección Trabajos de Investigación. 
El diálogo nos forja. Infancia y ciudadanía es un libro producto de la reflexión sobre la educación cuyo eje articulador es el clima de reformas educativas que se inician en toda América Latina y Colombia desde los años 70, se amplía en los 80 , se consolida en los 90 y continúan vigentes. El volcamiento de la mirada a la educación inicial, las reformas del componente pedagógico y el rescate del lenguaje como herramienta vital para movilizar pensamiento, son algunas apuestas. La democratización de la escuela pasó por la redefinición de las relaciones de poder, por el reconocimiento recíproco de los derechos fundamentales de los integrantes de la comunidad educativa y la libertad, como expresión de conciencia, como libre desarrollo de la personalidad y como autonomía moral. Se pensaba que la democracia en la escuela se construía justamente a partir del reconocimiento pleno de los derechos, hecho que suponía un cambio radical en el papel del maestro, que ahora debía ser el dinamizador del proceso de aprendizaje, uno más en la institución. La escuela fue inundada de programas y planes, en ocasiones sin mucha reflexión sobre las bases teóricas y epistemológicas desde las que se abordaban temas como la ética, los derechos, los valores, la moral, la democracia, la ciudadanía y la participación, inclusive. 